\title{
Seasonal carbonate chemistry variability in marine surface waters of the US Pacific Northwest
}

\author{
Andrea J. Fassbender ${ }^{1,2}$, Simone R. Alin ${ }^{2}$, Richard A. Feely ${ }^{2}$, Adrienne J. Sutton ${ }^{2}$, Jan A. Newton ${ }^{3}$, \\ Christopher Krembs $^{4}$, Julia Bos ${ }^{4}$, Mya Keyzers ${ }^{4}$, Allan Devol ${ }^{5}$, Wendi Ruef ${ }^{5}$, and Greg Pelletier ${ }^{4}$ \\ ${ }^{1}$ Monterey Bay Aquarium Research Institute, Moss Landing, CA 95039, USA \\ ${ }^{2}$ Pacific Marine Environmental Laboratory, National Oceanic and Atmospheric Administration, \\ Seattle, WA 98115, USA \\ ${ }^{3}$ Applied Physics Laboratory, University of Washington, Seattle, WA 98105, USA \\ ${ }^{4}$ Washington State Department of Ecology, Olympia, WA 98504, USA \\ ${ }^{5}$ School of Oceanography, University of Washington, Seattle, WA 98195, USA
}

Correspondence: Andrea J. Fassbender (fassbender@mbari.org)

Received: 14 December 2017 - Discussion started: 21 March 2018

Revised: 21 June 2018 - Accepted: 22 June 2018 - Published: 30 July 2018

\begin{abstract}
Fingerprinting ocean acidification (OA) in US West Coast waters is extremely challenging due to the large magnitude of natural carbonate chemistry variations common to these regions. Additionally, quantifying a change requires information about the initial conditions, which is not readily available in most coastal systems. In an effort to address this issue, we have collated high-quality publicly available data to characterize the modern seasonal carbonate chemistry variability in marine surface waters of the US Pacific Northwest. Underway ship data from version 4 of the Surface Ocean $\mathrm{CO}_{2}$ Atlas, discrete observations from various sampling platforms, and sustained measurements from regional moorings were incorporated to provide $\sim 100000$ inorganic carbon observations from which modern seasonal cycles were estimated. Underway ship and discrete observations were merged and gridded to a $0.1^{\circ} \times 0.1^{\circ}$ scale. Eight unique regions were identified and seasonal cycles from grid cells within each region were averaged. Data from nine surface moorings were also compiled and used to develop robust estimates of mean seasonal cycles for comparison with the eight regions. This manuscript describes our methodology and the resulting mean seasonal cycles for multiple OA metrics in an effort to provide a largescale environmental context for ongoing research, adaptation, and management efforts throughout the US Pacific Northwest. Major findings include the identification of unique chemical characteristics across the study domain. There is a clear increase in the ratio of dissolved inorganic carbon (DIC) to total alkalinity (TA) and in the seasonal cycle amplitude of carbonate system parameters when moving from the open ocean North Pacific into the Salish Sea. Due to the logarithmic nature of the $\mathrm{pH}$ scale $\left(\mathrm{pH}=-\log _{10}\left[\mathrm{H}^{+}\right]\right.$, where $\left[\mathrm{H}^{+}\right]$is the hydrogen ion concentration), lower annual mean $\mathrm{pH}$ values (associated with elevated DIC : TA ratios) coupled with larger magnitude seasonal $\mathrm{pH}$ cycles results in seasonal $\left[\mathrm{H}^{+}\right]$ranges that are $\sim 27$ times larger in Hood Canal than in the neighboring North Pacific open ocean. Organisms living in the Salish Sea are thus exposed to much larger seasonal acidity changes than those living in nearby open ocean waters. Additionally, our findings suggest that lower buffering capacities in the Salish Sea make these waters less efficient at absorbing anthropogenic carbon than open ocean waters at the same latitude.
\end{abstract}

All data used in this analysis are publically available at the following websites:

- Surface Ocean $\mathrm{CO}_{2}$ Atlas version 4 coastal data, https://doi.pangaea.de/10.1594/PANGAEA. 866856 (Bakker et al., 2016a);

- National Oceanic and Atmospheric Administration (NOAA) West Coast Ocean Acidification cruise data, https://doi.org/10.3334/CDIAC/otg.CLIVAR_NACP_West_Coast_Cruise_2007 (Feely and Sabine, 2013); https://doi.org/10.7289/V5JQ0XZ1 (Feely et al., 2015b); 
https://data.nodc.noaa.gov/cgi-bin/iso?id=gov.noaa.nodc:0157445 (Feely et al., 2016a); https://doi.org/10.7289/V5C53HXP (Feely et al., 2015a);

- University of Washington (UW) and Washington Ocean Acidification Center cruise data, https://doi.org/10. 5281/zenodo.1184657 (Fassbender et al., 2018);

- Washington State Department of Ecology seaplane data, https://doi.org/10.5281/zenodo.1184657 (Fassbender et al., 2018);

- NOAA Moored Autonomous $p \mathrm{CO}_{2}$ (MAPCO2) buoy data, https://doi.org/10.3334/CDIAC/OTG.TSM_ LAPUSH_125W_48N (Sutton et al., 2012); https://doi.org/10.3334/CDIAC/OTG.TSM_WA_125W_ 47N (Sutton et al., 2013); https://doi.org/10.3334/CDIAC/OTG.TSM_DABOB_122W_478N (Sutton et al., 2014a); https://doi.org/10.3334/CDIAC/OTG.TSM_TWANOH_123W_47N (Sutton et al., 2016a);

- UW Oceanic Remote Chemical/Optical Analyzer buoy data, https://doi.org/10.5281/zenodo.1184657 (Fassbender et al., 2018);

- NOAA Pacific Coast Ocean Observing System cruise data, https://doi.org/10.5281/zenodo.1184657 (Fassbender et al., 2018).

1

\section{Introduction}

Changes in seawater chemistry caused by the continuous absorption of anthropogenic carbon dioxide $\left(\mathrm{CO}_{2}\right)$ from the atmosphere are altering the marine environment in ways that are often invisible to the human eye but may resonate throughout coastal communities in the form of altered ecosystem health and economic vulnerabilities associated with food security (e.g., Adelsman and Binder, 2012; Wong et al., 2014; Barton et al., 2015; Ekstrom et al., 2015; Somero et al., 2016). Rising $\mathrm{CO}_{2}$ partial pressures $\left(p \mathrm{CO}_{2}\right)$ and hydrogen ion concentrations $\left(\left[\mathrm{H}^{+}\right]\right)$, commonly referred to as "ocean acidification" (OA; Caldeira and Wickett, 2003; Doney et al., 2009), have been observed throughout the global open ocean (e.g., Brewer, 1978; Sabine, 2004; Feely et al., 2004, 2009; Bates et al., 2014). Yet, in the coastal zone, it remains challenging to attribute carbonate chemistry changes to anthropogenic factors due to the much larger and more sporadic natural chemical variations that take place near shore (Borges, 2011; Evans et al., 2011; Fassbender et al., 2016; Feely et al., 2016b; Harris, 2013; Waldbusser and Salisbury, 2014; Takeshita et al., 2015). Unlike the open ocean, the coastal zone is complicated by land-sea interactions (e.g., river input, upwelling, point source pollution, as well as tidal and estuarine mixing) that influence water and chemical residence times as well as carbon transformation processes, and these may also be changing over time due to human activities (Raymond and Cole, 2003; Raymond et al., 2008; Cai et al., 2011; Bauer et al., 2013; Regnier et al., 2013; Feely et al., 2016b). Baseline observations capturing the range of modern variability in the coastal ocean will therefore be required to accurately fingerprint the ongoing carbonate system changes associated with human perturbations to the global climate system.
Washington State has an expansive coastline where a diversity of land-sea interfaces results in regional patchiness, requiring local assessments of OA that cannot be inferred from the broader North Pacific Ocean (e.g., Feely et al., 2010). Monthly pH observations have been collected throughout Washington waters since 1989 by the Washington State Department of Ecology (ECY) using electrodebased $\mathrm{pH}$ measurements with known accuracy and precision limitations. The use of a consistent method has allowed ECY to perform intensive quality assurance (Bos et al., 2016), leading to the detection of interannual variability and secular trends in $\mathrm{pH}$ over the data record. Still, great uncertainty remains in how other carbonate system parameters have changed throughout the region. In 2006, the National Oceanic and Atmospheric Administration (NOAA) and the University of Washington (UW) began sustained high-frequency $(3 \mathrm{~h})$ observations of carbonate chemistry in Washington waters with the deployment of an autonomous $\mathrm{CO}_{2}$ sensor on a surface mooring. Three additional surface moorings have been outfitted with $\mathrm{CO}_{2}$ sensors since 2009 (Alin et al., 2015). Routine discrete sampling of two carbonate system parameters conducted by NOAA and regional partners started in 2007 (Feely et al., 2008, 2010, 2016b), and the deployment of autonomous $\mathrm{pH}$ sensors on regional surface moorings was initiated by the UW and NOAA in 2010. In addition to these targeted carbon observations, $\mathrm{CO}_{2}$ measurements collected opportunistically from ships that are underway have amassed throughout the region since the 1970s (Bakker et al., 2016b). Altogether these data, in addition to measurements made by a large community of agencies, institutions, and stakeholders, constitute an impressive network of observations that makes Washington one of the most datarich states to tackle research questions associated with $\mathrm{OA}$ in the coastal zone (Alin et al., 2015). 
Building upon these observing efforts, we have characterized the average seasonal cycles of numerous carbonate system parameters throughout US Pacific Northwest marine surface waters. Comprised of high-quality publicly available data, the resulting data products are meant to provide largescale environmental context for OA research (Hofmann et al., 2011; Andersson and MacKenzie, 2012; McElhany and Busch, 2013; Takeshita et al., 2015; Wahl et al., 2016), adaptation and management strategy development (Boehm et al., 2015; Ekstrom et al., 2015), and water quality assessment (Weisberg et al., 2016; Bednaršek et al., 2017). Here we describe our methodology and the resulting carbonate chemistry seasonal cycles, reproduced in the netCDF format as supplementary material to this article (contact the author for similar information in MATLAB format).

\section{Data sources}

\subsection{Surface Ocean $\mathrm{CO}_{2}$ Atlas version 4}

The Surface Ocean $\mathrm{CO}_{2}$ Atlas (SOCAT; http://www.socat. info/, last access: 14 December 2017) is the result of a data synthesis activity carried out by $>100$ members of the carbon research community who compile and quality control sea surface (upper $\sim 5 \mathrm{~m}$ ) measurements of $\mathrm{CO}_{2}$ fugacity $\left(f \mathrm{CO}_{2}\right)$ made across the globe (Pfeil et al., 2013; Sabine et al., 2013; Bakker et al., 2016b), where $f \mathrm{CO}_{2}$ is similar to $p \mathrm{CO}_{2}$ but takes into account the non-ideal nature of the gas (Dickson et al., 2007). The SOCAT database is updated annually to include the most recent observations as well as historical data files that have been discovered and validated. For this analysis, SOCAT version 4 (SOCAT-v4) $f \mathrm{CO}_{2}$ data collected within 45.5 to $49^{\circ} \mathrm{N}$ and 127 to $122^{\circ} \mathrm{W}$ (Fig. 1a) were downloaded from the coastal SOCAT database (Table 1) along with the accompanying sea surface salinity (SSS) and sea surface temperature (SST) observations. World Ocean Circulation Experiment quality control flags of 2 ("good") and SOCAT metadata flags of A through D were applied such that the $f \mathrm{CO}_{2}$ observations included have an accuracy of $5 \mu \mathrm{atm}$ or better (Bakker et al., 2016b). Mooring observations found within the study region were removed from the SOCAT-v4 dataset and are treated separately. The resultant dataset includes $\sim 57000$ quality-controlled $f \mathrm{CO}_{2}$ observations collected between 1976 and 2015 (Table 2). Because these observations span four decades, a seawater anthropogenic $p \mathrm{CO}_{2}$ trend of $1.5 \mu \mathrm{atm} \mathrm{yr}^{-1}$ was used to normalize the $f \mathrm{CO}_{2}$ observations to the reference year 2010, following Takahashi et al. $(2009,2014)$. Although a trend in $p \mathrm{CO}_{2}$ rather than $f \mathrm{CO}_{2}$ was used, the difference in trend between the two parameters is negligible over a 40-year period $\left(\sim 0.006 \mu \mathrm{atm} \mathrm{yr}^{-1}\right)$, resulting in a $0.2 \mu \mathrm{atm}$ absolute difference between parameters.

\subsection{Discrete carbon data}

Discrete samples collected from the top $10 \mathrm{~m}$ of water during recurring oceanographic cruises conducted between May 2007 and May 2015 near Washington State were compiled for this analysis (Fig. 1a). These cruises include: NOAA Ocean Acidification Program (OAP) West Coast Ocean Acidification (WCOA) cruises; Pacific Coast Ocean Observing System (PacOOS) cruises; and UW cruises associated with the Puget Sound Regional Synthesis Model (PRISM) program, Washington Ocean Acidification Center (WOAC), and Northwest Association of Networked Ocean Observing Systems (NANOOS) as well as its Chá bă mooring. Additionally, ECY collected discrete water samples via seaplane from $\sim 5 \mathrm{~m}$ depth during 2014 and 2015 (Keyzers, 2014, 2016). Each data subset used herein can be accessed online using information from Table 1.

Discrete samples with quality control flags of 2 or 6 ( $2=$ good data, $6=$ replicate samples) were included, yielding $\sim 900$ observations. Table 2 provides a detailed list of the cruises, number of dissolved inorganic carbon (DIC), total alkalinity (TA), total $\mathrm{pH}\left(\mathrm{pH}_{\mathrm{T}}\right), f \mathrm{CO}_{2}$, salinity, and temperature observations relied on from each cruise. For simplicity, the acronyms SSS and SST are used hereafter to refer to all upper water column (i.e., $\leq 10 \mathrm{~m}$ ) observations of salinity and temperature, respectively. Information about the silicate and phosphate observations that were also used in this analysis can be found in Appendix A. All of the DIC and TA bottle samples were analyzed at the Pacific Marine Environmental Laboratory via coulometric (Johnson et al., 1998; Dickson et al., 2007) and potentiometric titration (Millero et al., 1993; Dickson et al., 2007), respectively. For all cruises, the accuracy of DIC and TA relative to certified reference materials (Dickson et al., 2007) is $\pm 0.1 \%$ of the measurement value and the precision is $< \pm 0.1 \%$ for TA and $\sim 1 \mu \mathrm{mol} \mathrm{kg}{ }^{-1}$ for DIC. This is equal to an accuracy of approximately $2 \mu \mathrm{mol} \mathrm{kg}^{-1}$ for both parameters in Washington surface waters. For simplicity, we use $2 \mu \mathrm{mol} \mathrm{kg} \mathrm{kg}^{-1}$ as the total uncertainty for DIC and TA samples and discuss the role of measurement error further in Sect. 4.2. Measurements of $\mathrm{pH}_{\mathrm{T}}$ were made during the 2011 and 2013 WCOA cruises (Table 2). These samples were analyzed by spectrophotometry using purified dye (Byrne et al., 2010; Liu et al., 2011) and have measurement accuracies of \pm 0.01 and precisions of \pm 0.0004 .

\subsection{Mooring carbon data}

Time-series observations from nine surface moorings in the region are included in the analysis (Fig. 1a). These moorings are maintained by NOAA, UW, WOAC, and NANOOS. Moored time-series data can be accessed online using information from Table 3. All of the moorings carry sensors that measure SST and SSS, and most include sensors for surface ocean $f \mathrm{CO}_{2}$ or $\mathrm{pH}_{\mathrm{T}}$, while the Chá bă mooring measures 
(a) SOCAT-v4, discrete, and moored observation locations

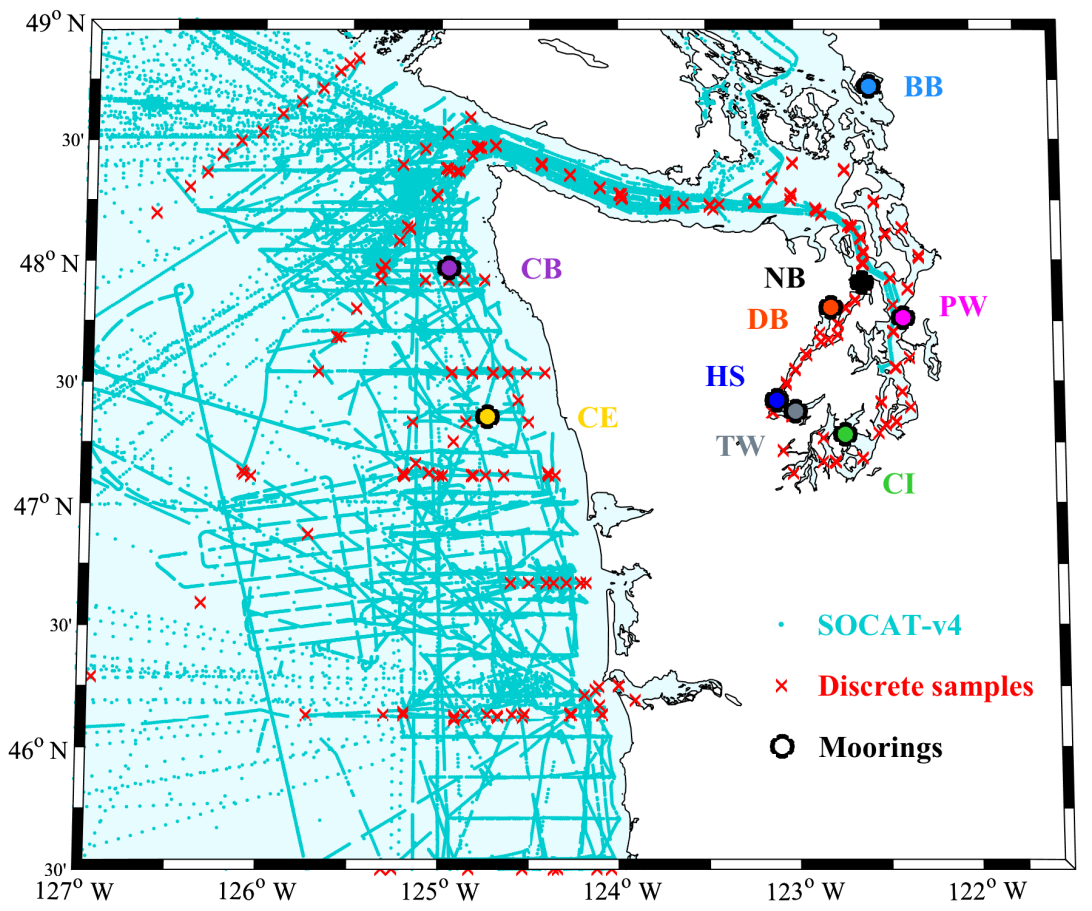

(b) Moored time series observation intervals

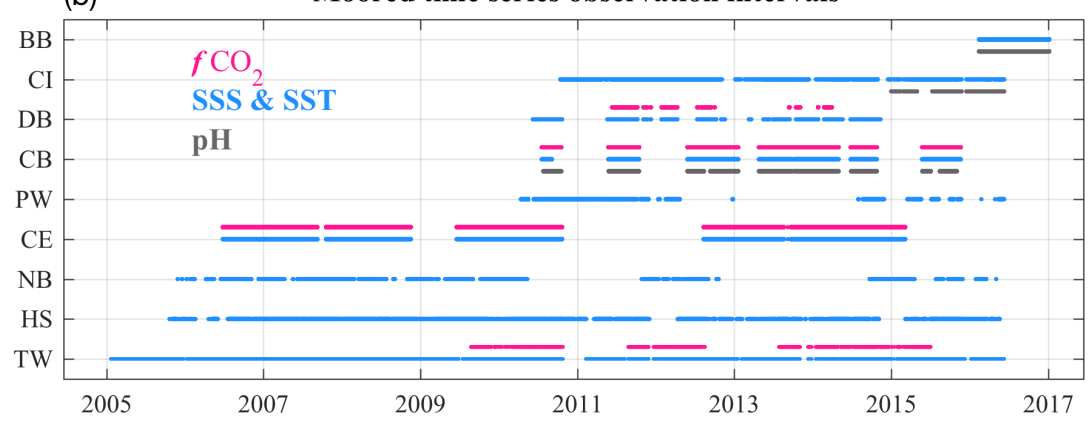

Figure 1. (a) Locations of coastal SOCAT-v4 $f \mathrm{CO}_{2}$ observations, discrete sample stations, and moorings. The moorings are labeled with two-letter acronyms as follows: Bellingham Bay (BB), Carr Inlet (CI), Dabob Bay (DB), Chá bă (CB), Point Wells (PW), Cape Elizabeth (CE), North Buoy (NB), Hoodsport (HS), and Twanoh (TW). (b) Intervals of available sensor data from each of the nine moorings. All moorings include salinity (SSS) and temperature (SST) observations (blue). Some moorings also include $\mathrm{pH}$ (gray) and/or $f \mathrm{CO}_{2}$ (pink) observations.

both of these carbon parameters (Fig. 1b). Presently, qualitycontrolled observations from the moorings range from January 2005 through January 2017, with the longest carbon record from the Cape Elizabeth mooring that started in 2006. Assuming the same anthropogenic $f \mathrm{CO}_{2}$ trend of $1.5 \mu \mathrm{atm} \mathrm{yr}^{-1}$ that was used to normalize the SOCAT-v4 data (Takahashi et al., 2009, 2014), the Cape Elizabeth time series may include $\mathrm{a} \sim 12 \mu \mathrm{atm}$ anthropogenic increase in the mean $f \mathrm{CO}_{2}$ over the 8 -year record. This is much smaller than the potential $\sim 60 \mu \mathrm{atm}$ increase over the $\sim 40$-year SOCATv4 record. Additionally, since all other moorings have much shorter carbon time series (some with $\mathrm{pH}$ rather than $f \mathrm{CO}_{2}$ records), we do not remove the anthropogenic $f \mathrm{CO}_{2}$ trend from the mooring data.

The Chá bă, Cape Elizabeth, Dabob Bay, and Twanoh surface moorings each carry a moored autonomous $p \mathrm{CO}_{2}$ (MAPCO2) system that makes $3 \mathrm{~h}$ measurements of surface air and sea $p \mathrm{CO}_{2}$ with an accuracy of $\leq 2 \mu \mathrm{atm}$ (Sutton et al., 2014b). The Chá bă mooring is also outfitted with a Sunburst SAMI $\mathrm{pH}$ sensor with reported field accuracy of 0.018, and a Sea-Bird Electronics (SBE) 16plus V2 Sea-CAT conductivity-temperature-depth (CTD) sensor with SST accuracy $<0.01$ and SSS accuracy $<0.05$, as described in Sutton et al. (2016b). The Cape Elizabeth mooring carries an SBE 37 MicroCAT CTD sensor with SST accuracy $<0.01$ 
Table 1. Data attribution table listing the SOCAT and discrete datasets (with observing periods) incorporated into the analysis. Data curating organization URLs and data DOIs are provided.

\begin{tabular}{|c|c|c|c|}
\hline $\begin{array}{l}\text { Discrete } \\
\text { Data }\end{array}$ & $\begin{array}{r}\text { Obs. } \\
\text { Period }\end{array}$ & Data curating organization URL & Data DOI \\
\hline SOCAT-v $4^{\mathrm{a}}$ & $1970-2015$ & https://doi.pangaea.de/10.1594/PANGAEA.866876 & https://doi.pangaea.de/10.1594/PANGAEA.866856 \\
\hline NOAA WCOA & $05 / 2007$ & https://www.nodc.noaa.gov/ocads/data/0083685.xml & https://doi.org/10.3334/CDIAC/otg.CLIVAR_NACP_West_Coast_Cruise_2007 \\
\hline UW PRISM ${ }^{b}$ & $02 / 2008$ & http://nvs.nanoos.org/CruiseSalish & https://doi.org/10.5281/zenodo.1184657 \\
\hline UW PRISM/EPA ${ }^{\mathrm{b}}$ & $08 / 2008$ & http://nvs.nanoos.org/CruiseSalish & https://doi.org/10.5281/zenodo.1184657 \\
\hline $\mathrm{PacOOS}^{\mathrm{b}}$ & 08/2009 & & https://doi.org/10.5281/zenodo.1184657 \\
\hline UW PRISM ${ }^{\mathrm{b}}$ & $09 / 2009$ & http://nvs.nanoos.org/CruiseSalish & https://doi.org/10.5281/zenodo. 1184657 \\
\hline PacOOS $^{b}$ & $05 / 2010$ & & https://doi.org/10.5281/zenodo.1184657 \\
\hline PacOOS $^{\mathrm{b}}$ & $08 / 2010$ & & https://doi.org/10.5281/zenodo. 1184657 \\
\hline UW PRISM $^{\mathrm{b}}$ & $11 / 2010$ & http://nvs.nanoos.org/CruiseSalish & https://doi.org/10.5281/zenodo. 1184657 \\
\hline UW/Chá bă ${ }^{b}$ & $05 / 2011$ & http://nvs.nanoos.org/CruiseSalish & https://doi.org/10.5281/zenodo.1184657 \\
\hline NOAA WCOA & 08/2011 & https://data.nodc.noaa.gov/cgi-bin/iso?id=gov.noaa.nodc: 0123467 & https://doi.org/10.7289/V5JQ0XZ1 \\
\hline UW PRISM $^{\mathrm{b}}$ & $10 / 2011$ & http://nvs.nanoos.org/CruiseSalish & https://doi.org/10.5281/zenodo. 1184657 \\
\hline UW/NANOOS ${ }^{\mathrm{b}}$ & $05 / 2012$ & http://nvs.nanoos.org/CruiseSalish & https://doi.org/10.5281/zenodo.1184657 \\
\hline NOAA WCOA & 09/2012 & https://www.nodc.noaa.gov/ocads/data/0157445.xml & https://data.nodc.noaa.gov/cgi-bin/iso?id=gov.noaa.nodc: 0157445 \\
\hline UW/Chá băb & $01 / 2013$ & http://nvs.nanoos.org/CruiseSalish & https://doi.org/10.5281/zenodo.1184657 \\
\hline UW/NANOOS ${ }^{\mathrm{b}}$ & $04 / 2013$ & http://nvs.nanoos.org/CruiseSalish & https://doi.org/10.5281/zenodo.1184657 \\
\hline NOAA WCOA & $08 / 2013$ & https://www.nodc.noaa.gov/oceanacidification/data/0132082.xml & https://doi.org/10.7289/V5C53HXP \\
\hline UW/NANOOS ${ }^{\mathrm{b}}$ & 09/2013 & http://nvs.nanoos.org/CruiseSalish & https://doi.org/10.5281/zenodo.1184657 \\
\hline UW/NANOOS ${ }^{\mathrm{b}}$ & $06 / 2014$ & http://nvs.nanoos.org/CruiseSalish & https://doi.org/10.5281/zenodo. 1184657 \\
\hline ECY & $06 / 2014$ & https://fortress.wa.gov/ecy/publications/SummaryPages/1603032.html & https://doi.org/10.5281/zenodo.1184657 \\
\hline WOAC $^{\mathrm{b}}$ & $07 / 2014$ & http://nvs.nanoos.org/CruiseSalish & https://doi.org/10.5281/zenodo.1184657 \\
\hline ECY & 07/2014 & https://fortress.wa.gov/ecy/publications/SummaryPages/1603032.html & https://doi.org/10.5281/zenodo.1184657 \\
\hline ECY & $08 / 2014$ & https://fortress.wa.gov/ecy/publications/SummaryPages/1603032.html & https://doi.org/10.5281/zenodo.1184657 \\
\hline WOAC $^{\mathrm{b}}$ & $09 / 2014$ & http://nvs.nanoos.org/CruiseSalish & https://doi.org/10.5281/zenodo. 1184657 \\
\hline ECY & $09 / 2014$ & https://fortress.wa.gov/ecy/publications/SummaryPages/1603032.html & https://doi.org/10.5281/zenodo.1184657 \\
\hline UW/Chá băb & $10 / 2014$ & http://nvs.nanoos.org/CruiseSalish & https://doi.org/10.5281/zenodo. 1184657 \\
\hline ECY & $10 / 2014$ & https://fortress.wa.gov/ecy/publications/SummaryPages/1603032.html & https://doi.org/10.5281/zenodo.1184657 \\
\hline ECY & $11 / 2014$ & https://fortress.wa.gov/ecy/publications/SummaryPages/1603032.html & https://doi.org/10.5281/zenodo.1184657 \\
\hline ECY & $01 / 2015$ & https://fortress.wa.gov/ecy/publications/SummaryPages/1603032.html & https://doi.org/10.5281/zenodo.1184657 \\
\hline ECY & $02 / 2015$ & https://fortress.wa.gov/ecy/publications/SummaryPages/1603032.html & https://doi.org/10.5281/zenodo.1184657 \\
\hline ECY & $03 / 2015$ & https://fortress.wa.gov/ecy/publications/SummaryPages/1603032.html & https://doi.org/10.5281/zenodo.1184657 \\
\hline ECY & $04 / 2015$ & https://fortress.wa.gov/ecy/publications/SummaryPages/1603032.html & https://doi.org/10.5281/zenodo.1184657 \\
\hline ECY & $05 / 2015$ & https://fortress.wa.gov/ecy/publications/SummaryPages/1603032.html & https://doi.org/10.5281/zenodo.1184657 \\
\hline
\end{tabular}

a The coastal subset of SOCAT-v4 data can be easily accessed here: https://www.socat.info/index.php/version- $4 /$; $^{\text {b }}$ Full dataset in preparation for submission to a long-term data repository.

and SSS accuracy $<0.05$. These sensors are programed to sample every 3 hours in tandem with the MAPCO2 system. The other seven moorings, Oceanic Remote Chemical/Optical Analyzer (ORCA) buoys (Dunne et al., 2002), are equipped with profiling sensors that include SBE19 or 19Plus CTD sensors (SST accuracy of 0.005 and SSS accuracy of 0.005), SBE 43 dissolved oxygen sensors, and WETLabs WETStar or FLNTUS chlorophyll fluorometers. Temperature and salinity observations collected from the top $3 \mathrm{~m}$ of the water column were binned and averaged to serve as SST and SSS for this analysis. The Carr Inlet and Bellingham Bay surface buoys also carry Satlantic SeaFET $\mathrm{pH}$ sensors with a reported accuracy of $\pm 0.05 \mathrm{pH}$. All raw SeaFET measurements were converted to $\mathrm{pH}$ using custom code adapted from Martz et al. (2015) and equations from Bresnahan et al. (2014). ORCA mooring data were quality controlled according to protocols outlined in the Quality Assurance Project Plan (http://nwem.ocean.washington.edu/ ORCA_QAPP.pdf, last access: 14 December 2017; Newton and Devol, 2012). All sensors on the surface buoys sample the water column at $\sim 1 \mathrm{~m}$ depth, excluding the profiling CTDs. Details about the number of observations collected at each mooring location are provided in Table 4. It is important to note that many of the moored time series include significant data gaps and/or times when $f \mathrm{CO}_{2}$ and $\mathrm{pH}_{\mathrm{T}}$ mea- surements are not available (Fig. 1b). The observing periods listed in Table 3 represent the time range over which qualitycontrolled in situ observations exist at the mooring site at the time of this manuscript.

\section{Methods}

\subsection{Leveraging the carbon datasets}

Seawater carbonate chemistry can be fully characterized with information about salinity, temperature, pressure, weak acids that contribute to TA (e.g., phosphoric and silicic acid), and two of the four commonly measured carbonate system parameters: DIC, TA, $p \mathrm{CO}_{2}$ (or $f \mathrm{CO}_{2}$ ), and $\mathrm{pH}$ (Dickson and Riley, 1978; Millero, 2007). In order to leverage the numerous SOCAT-v4 $f \mathrm{CO}_{2}$ observations that lack a second carbonate system parameter, a previously characterized relationship between near-surface $(\leq 25 \mathrm{~m})$ salinity and TA $(\mathrm{TA}=47.7 \times$ Salinity +647$)$ for marine surface waters near Washington (Fassbender et al., 2017a) was used to estimate TA from the SOCAT-v4 SSS observations. This relationship yields TA estimates that have an uncertainty $\leq \pm 34 \mu \mathrm{mol} \mathrm{kg}^{-1}$ at the $95 \%$ confidence level $(2 \sigma)$ for waters with salinity $\geq 20$ (Fassbender et al., 2017a). Uncertainties may be larger in the salinity range of 20 to 27 $(2 \sigma= \pm 94 \mu \mathrm{mol} \mathrm{kg}-1)$; however, only $\sim 2 \%$ of the SOCAT- 
Table 2. SOCAT and discrete datasets incorporated into the analysis. The observing period and the number of $f \mathrm{CO}_{2}$, DIC, TA, pH, SSS, and SST values that were observed (Obs.), calculated (Calc.), and estimated (Est.) for each cruise are provided.

\begin{tabular}{|c|c|c|c|c|c|c|c|c|c|c|c|}
\hline \multirow{2}{*}{$\begin{array}{l}\text { Discrete } \\
\text { Data }\end{array}$} & \multirow{2}{*}{$\begin{array}{r}\text { Obs. } \\
\text { Period }\end{array}$} & \multicolumn{2}{|c|}{$f \mathrm{CO}_{2}$} & \multicolumn{2}{|c|}{ DIC } & \multicolumn{2}{|c|}{ TA } & \multicolumn{2}{|c|}{$\mathrm{pH}_{\mathrm{T}}$} & \multirow{2}{*}{$\begin{array}{l}\text { SSS } \\
\text { Obs. }\end{array}$} & \multirow{2}{*}{$\begin{array}{l}\text { SST } \\
\text { Obs. }\end{array}$} \\
\hline & & Obs. & Calc. & Obs. & Calc. & Obs. & Est. & Obs. & Calc. & & \\
\hline SOCAT-v4 & 1976-2015 & 57425 & 0 & 0 & 52521 & 0 & 52524 & 0 & 52521 & 52528 & 57422 \\
\hline NOAA WCOA & $05 / 2007$ & 0 & 11 & 11 & 0 & 11 & 0 & 0 & 11 & 11 & 11 \\
\hline UW PRISM & $02 / 2008$ & 0 & 80 & 80 & 0 & 75 & 5 & 0 & 80 & 80 & 80 \\
\hline UW PRISM/EPA & $08 / 2008$ & 0 & 122 & 122 & 0 & 120 & 2 & 0 & 122 & 122 & 122 \\
\hline PacOOS & $08 / 2009$ & 0 & 8 & 8 & 0 & 8 & 0 & 0 & 8 & 8 & 8 \\
\hline UW PRISM & $09 / 2009$ & 0 & 38 & 38 & 0 & 38 & 0 & 0 & 38 & 38 & 38 \\
\hline PacOOS & $05 / 2010$ & 0 & 13 & 13 & 0 & 13 & 0 & 0 & 13 & 13 & 13 \\
\hline PacOOS & $08 / 2010$ & 0 & 22 & 22 & 0 & 22 & 0 & 0 & 22 & 22 & 22 \\
\hline UW PRISM & $11 / 2010$ & 0 & 40 & 40 & 0 & 37 & 3 & 0 & 40 & 40 & 40 \\
\hline UW/Chá bă & $05 / 2011$ & 0 & 1 & 1 & 0 & 1 & 0 & 0 & 1 & 1 & 1 \\
\hline NOAA WCOA & 08/2011 & 0 & 37 & 37 & 0 & 32 & 5 & 32 & 5 & 37 & 37 \\
\hline UW PRISM & $10 / 2011$ & 0 & 60 & 60 & 0 & 60 & 0 & 0 & 60 & 60 & 60 \\
\hline UW/NANOOS & $05 / 2012$ & 0 & 4 & 4 & 0 & 4 & 0 & 0 & 4 & 4 & 4 \\
\hline NOAA WCOA & $09 / 2012$ & 0 & 43 & 43 & 0 & 39 & 3 & 0 & 43 & 43 & 43 \\
\hline UW/Chá bă & $01 / 2013$ & 0 & 2 & 2 & 0 & 2 & 0 & 0 & 2 & 2 & 2 \\
\hline UW/NANOOS & $04 / 2013$ & 0 & 19 & 19 & 0 & 18 & 1 & 0 & 19 & 19 & 19 \\
\hline NOAA WCOA & $08 / 2013$ & 0 & 59 & 59 & 0 & 47 & 9 & 45 & 14 & 59 & 59 \\
\hline UW/NANOOS & $09 / 2013$ & 0 & 19 & 19 & 0 & 19 & 0 & 0 & 19 & 19 & 19 \\
\hline UW/NANOOS & $06 / 2014$ & 0 & 10 & 10 & 0 & 10 & 0 & 0 & 10 & 10 & 10 \\
\hline ECY & 06/2014 & 0 & 17 & 17 & 0 & 17 & 0 & 0 & 17 & 17 & 17 \\
\hline WOAC & $07 / 2014$ & 0 & 68 & 68 & 0 & 68 & 0 & 0 & 68 & 68 & 68 \\
\hline $\mathrm{ECY}$ & $07 / 2014$ & 0 & 12 & 12 & 0 & 12 & 0 & 0 & 12 & 12 & 12 \\
\hline ECY & 08/2014 & 0 & 18 & 18 & 0 & 18 & 0 & 0 & 18 & 18 & 18 \\
\hline WOAC & $09 / 2014$ & 0 & 64 & 64 & 0 & 64 & 0 & 0 & 64 & 64 & 64 \\
\hline ECY & $09 / 2014$ & 0 & 14 & 14 & 0 & 14 & 0 & 0 & 14 & 14 & 14 \\
\hline UW/Chá bă & $10 / 2014$ & 0 & 19 & 19 & 0 & 19 & 0 & 0 & 19 & 19 & 19 \\
\hline $\mathrm{ECY}$ & $10 / 2014$ & 0 & 9 & 9 & 0 & 9 & 0 & 0 & 9 & 9 & 9 \\
\hline ECY & $11 / 2014$ & 0 & 9 & 9 & 0 & 9 & 0 & 0 & 9 & 9 & 9 \\
\hline ECY & $01 / 2015$ & 0 & 13 & 13 & 0 & 13 & 0 & 0 & 13 & 13 & 13 \\
\hline ECY & $02 / 2015$ & 0 & 15 & 15 & 0 & 15 & 0 & 0 & 15 & 15 & 15 \\
\hline ECY & $03 / 2015$ & 0 & 20 & 20 & 0 & 20 & 0 & 0 & 20 & 20 & 20 \\
\hline ECY & $04 / 2015$ & 0 & 15 & 15 & 0 & 15 & 0 & 0 & 15 & 15 & 15 \\
\hline ECY & $05 / 2015$ & 0 & 6 & 6 & 0 & 6 & 0 & 0 & 6 & 6 & 6 \\
\hline Total & & 57425 & 887 & 887 & 52521 & 855 & 52552 & 77 & 53331 & 53415 & 58309 \\
\hline
\end{tabular}

Table 3. Data attribution table listing the mooring datasets (with observing periods) incorporated into the analysis. Data curating organization URLs and data DOIs are provided.

\begin{tabular}{llll}
\hline Mooring Data & Obs. Period & Data curating organization URL & Data DOI \\
\hline Chá bă $^{\mathrm{a}}$ & $07 / 10-10 / 15$ & https://www.nodc.noaa.gov/ocads/data/0100072.xml & https://doi.org/10.3334/CDIAC/OTG.TSM_LAPUSH_125W_48N \\
Cape Elizabeth & $06 / 06-09 / 13$ & https://www.nodc.noaa.gov/ocads/data/0115322.xml & https://doi.org/10.3334/CDIAC/OTG.TSM_WA_125W_47N \\
Dabob Bayb & $06 / 10-11 / 14$ & https://www.nodc.noaa.gov/ocads/data/0116715.xml & https://doi.org/10.3334/CDIAC/OTG.TSM_DABOB_122W_478N \\
Twanoh $^{b}$ & $01 / 05-06 / 16$ & https://www.nodc.noaa.gov/ocads/data/0157600.xml & https://doi.org/10.3334/CDIAC/OTG.TSM_TWANOH_123W_47N \\
Carr Inlet & $10 / 10-06 / 16$ & http://nwem.ocean.washington.edu/prod_DataReq.shtml & https://doi.org/10.5281/zenodo.1184657 \\
Bellingham Bay & $02 / 16-01 / 17$ & http://nwem.ocean.washington.edu/prod_DataReq.shtml & https://doi.org/10.5281/zenodo.1184657 \\
Hoodsport & $10 / 05-05 / 16$ & http://nwem.ocean.washington.edu/prod_DataReq.shtml & https://doi.org/10.5281/zenodo.1184657 \\
Point Wells & $04 / 10-06 / 16$ & http://nwem.ocean.washington.edu/prod_DataReq.shtml & https://doi.org/10.5281/zenodo.1184657 \\
North Buoy & $11 / 05-05 / 16$ & http://nwem.ocean.washington.edu/prod_DataReq.shtml & https://doi.org/10.5281/zenodo.1184657 \\
\hline
\end{tabular}

${ }^{\mathrm{a}}$ The Chá bă mooring is referred to as the La Push mooring in the NOAA data repository. ${ }^{\mathrm{b}}$ Temperature and salinity data for the Dabob Bay and Twanoh moorings can be found here: https://doi.org/10.5281/zenodo.1184657.

v4 SSS observations are below salinity 27. TA was not estimated when SOCAT-v4 SSS values were below $20(n=4)$.
For more detailed information about how the TA-salinity relationship was characterized and a discussion of uncertain- 
Table 4. Mooring datasets incorporated into the analysis. The observing period and number of $f \mathrm{CO}_{2}$, DIC, TA, pH, SSS, and SST values that were observed (Obs.), calculated (Calc.), and estimated (Est.) are provided.

\begin{tabular}{lrrrrrrrrrrr}
\hline Mooring & \multicolumn{2}{c}{ Obs. } & \multicolumn{2}{c}{$f \mathrm{CO}_{2}$} & \multicolumn{2}{c}{ DIC } & \multicolumn{2}{c}{ TA } & pH & SSS & SST \\
Data & Period & Obs. & Calc. & Obs. & Calc. & Obs. & Est. & Obs. & Calc. & Obs. & Obs. \\
\hline Chá bă & $07 / 10-11 / 15$ & 9681 & 0 & 0 & 9330 & 0 & 9341 & 7438 & 2291 & 9341 & 9717 \\
Cape Elizabeth & $06 / 06-03 / 15$ & 17617 & 0 & 0 & 17617 & 0 & 17667 & 0 & 17617 & 17667 & 18009 \\
Dabob Bay & $06 / 10-11 / 14$ & 2076 & 0 & 0 & 2076 & 0 & 4662 & 0 & 2076 & 4662 & 4662 \\
Twanoh & $01 / 05-06 / 16$ & 9221 & 0 & 0 & 9221 & 0 & 28466 & 0 & 9221 & 28466 & 28466 \\
Carr Inlet & $10 / 10-06 / 16$ & 0 & 1848 & 0 & 1848 & 0 & 12369 & 1848 & 0 & 12369 & 12369 \\
Bellingham Bay & $02 / 16-01 / 17$ & 0 & 0 & 0 & 0 & 0 & 0 & 45583 & 0 & 44895 & 44895 \\
Hoodsport & $10 / 05-05 / 16$ & 0 & 0 & 0 & 0 & 0 & 17147 & 0 & 0 & 17186 & 17186 \\
Point Wells & $04 / 10-06 / 16$ & 0 & 0 & 0 & 0 & 0 & 4315 & 0 & 0 & 4315 & 4315 \\
North Buoy & $11 / 05-05 / 16$ & 0 & 0 & 0 & 0 & 0 & 10199 & 0 & 0 & 10199 & 10199 \\
\hline Total & & 38595 & 1848 & 0 & 40092 & 0 & 104166 & 54869 & 31205 & 149100 & 149818 \\
\hline
\end{tabular}

ties related to organic alkalinity, please see Fassbender et al. (2017a).

Estimated TA values and 2010-normalized SOCAT-v4 $f \mathrm{CO}_{2}$ data were used to calculate other carbonate system parameters of interest ("calculated" values in Table 2). All carbonate system calculations herein were made using the program CO2SYS version 1.1 (Lewis and Wallace, 1998; van Heuven et al., 2011) with the equilibrium constants of Lueker et al. (2000) and Dickson (1990) while applying the boronto-chlorinity ratio of Uppstrom, (1974), following the recommendations of Orr et al. (2015). SOCAT-v4 does not include nutrient observations, so all of the associated CO2SYS calculations were made with phosphate and silicate concentrations set to zero. The omission of nutrients when using the TA$f \mathrm{CO}_{2}$ pair to calculate other carbonate system parameters results in small errors. These errors were previously assessed for the TA $-p \mathrm{CO}_{2}$ pair within Washington waters (Fassbender et al., 2017a), and will be discussed further in Sect. 3.2.

TA and DIC were measured during discrete sampling efforts in addition to temperature, salinity, and pressure, and these data were used to calculate other carbonate system parameters of interest. Some of the discrete sample datasets lack nutrient observations, so phosphate and silicate concentrations were set to zero for the associated CO2SYS calculations. Nutrient omission when using the TA-DIC pair has a larger influence on calculated carbonate system parameters than the TA- $p \mathrm{CO}_{2}$ pair (Fassbender et al., 2017a), which will be addressed further in Sect. 3.2. In some cases, only DIC was measured. For these instances, TA was estimated from the previously mentioned regional TA-salinity relationship when salinity was $\geq 20$ (true of all discrete samples), making it possible to fully characterize the carbonate system as long as DIC, SST, and SSS data were available. Finally, on cruises in which $\mathrm{pH}_{\mathrm{T}}$ was measured directly, missing $\mathrm{pH}_{\mathrm{T}}$ observations were calculated from TA and DIC. Details about the specific number of measured, estimated, and calculated values for each parameter can be found in Table 2 .
Sustained, autonomous $f \mathrm{CO}_{2}$ and $\mathrm{pH}$ measurements made on some of the surface moorings located throughout the region (Fig. 1a) were also used to evaluate carbonate chemistry. The TA-salinity relationship was applied to the moored SSS observations to estimate TA for pairing with the in situ $f \mathrm{CO}_{2}$ or $\mathrm{pH}$ data (Fig. $1 \mathrm{~b}$; Table 4), allowing calculation of other carbonate system parameters of interest. For the Chá bă mooring, where $f \mathrm{CO}_{2}$ and $\mathrm{pH}$ measurements have been made simultaneously since $2010, f \mathrm{CO}_{2}$ and $\mathrm{TA}$ estimates were used to calculate additional carbonate system parameters due to challenges associated with constraining the carbonate system with the $f \mathrm{CO}_{2}-\mathrm{pH}$ pair (Dickson and Riley, 1978; Gray et al., 2011; Fassbender et al., 2015). At moorings limited to SSS and SST observations, TA was the only carbonate system parameter determined. Importantly, salinity at the Twanoh and Hoodsport moorings occasionally dropped below 20 throughout the observational record, and salinity at the Bellingham Bay mooring was often $<20$. These samples were not used to estimate TA. Because the occurrence of salinity $<20$ was infrequent at Twanoh and Hoodsport (1.7 and $0.2 \%$ of samples, respectively), the exclusion of these observations from seasonal cycle evaluations likely has a negligible impact. At Bellingham Bay, regular occurrences of salinity $<20$ ( $14 \%$ of samples) throughout all seasons renders the TA-salinity relationship unusable for a substantial fraction of the time series. Therefore, we do not calculate TA, or any other carbonate system parameters, and evaluate only in situ $\mathrm{pH}_{\mathrm{T}}$ observations from the Bellingham Bay mooring.

For this study, the carbonate system parameters of interest (either measured, estimated, or calculated) include: TA, DIC, $\mathrm{pH}_{\mathrm{T}}, f \mathrm{CO}_{2}$, aragonite saturation state $\left(\Omega_{\mathrm{Ar}}\right)$, and the Revelle factor (RF). $\Omega_{\mathrm{Ar}}$ represents the thermodynamic stability of aragonite in solution, where aragonite is a polymorph of the mineral calcium carbonate $\left(\mathrm{CaCO}_{3}\right)$. This stability is dependent on temperature, pressure, salinity, and the concentrations of calcium and carbonate ions (Mucci, 1983). By defini- 
tion, when $\Omega_{\mathrm{Ar}} \geq 1$, the mineral is thermodynamically stable. When $\Omega_{\mathrm{Ar}}<1$, the mineral is unstable and will begin to dissolve. This is relevant to the study of OA because many marine calcifying organisms make their shells out of aragonite and are susceptible to dissolution when exposed to waters with low (often $\Omega_{\mathrm{Ar}}<1$, but occasionally higher) aragonite saturation states (Feely et al.,2008; Doney et al., 2009; Barton et al., 2012; Bednaršek et al., 2014). The Revelle factor is analogous to the buffer capacity of the ocean (Revelle and Suess, 1957; Broecker et al., 1979; Sundquist et al., 1979; Takahashi et al., 1980) and provides information about how the carbonate system responds to change. Formally, $\mathrm{RF}$ is equal to the fractional change in $p \mathrm{CO}_{2}$ (or $f \mathrm{CO}_{2}$ ) divided by the fractional change in DIC resulting from a given perturbation, assuming constant TA. Lower RF values equate to more buffered systems that exhibit more efficient conversion of $\mathrm{CO}_{2}$ into other molecular forms of DIC (e.g., bicarbonate and carbonate ion), which enables additional seawater $\mathrm{CO}_{2}$ uptake. Thus, low RF regions are associated with larger anthropogenic carbon uptake through air-sea exchange relative to high RF regions (e.g., Sabine et al., 2004; Fassbender et al., 2017b).

\subsection{Errors associated with nutrient omission and estimating TA from salinity}

Silicate and phosphate contribute to TA (Dickson, 1981) and when omitted from CO2SYS can have a small but nonnegligible influence on the calculated carbonate system parameters. This was evaluated previously by Fassbender et al. (2017a) for many of the cruise data used herein; however, $\mathrm{RF}$ was not included in the analysis and the TA- $p \mathrm{CO}_{2}$ pair was used rather than the TA $-f \mathrm{CO}_{2}$ pair. Observations from regional cruises (Table 2) that include complete information about TA, DIC, phosphate, silicate, salinity, and temperature were used to calculate carbonate system parameters of interest using the observed nutrient concentrations and with nutrient concentrations set to zero. The analysis was conducted with both the TA-DIC pair and the TA- $f \mathrm{CO}_{2}$ pair as input parameters, where $f \mathrm{CO}_{2}$ values were initially calculated from TA and DIC using the observed nutrient concentrations. Differences between the computations made with and without nutrients are given in Table 5, displaying the larger influence of nutrient omission on calculations made from the TADIC pair than the TA- $f \mathrm{CO}_{2}$ pair for $\mathrm{pH}$ and $\Omega_{\mathrm{Ar}}$, though not for RF due to its strong dependence to the DIC: TA ratio.

In addition to missing nutrient data, there is uncertainty in the Washington TA-salinity relationship (Fassbender et al., 2017a), which characterizes a static mean condition from which deviations can occur in both space and time. Biases in the estimated TA value caused by departures from the mean condition may therefore create biases in the carbonate system parameters derived from it. This is of particular relevance in regard to leveraging the SOCAT-v4 and mooring datasets due to the explicit use of estimated TA to constrain the carbon- ate system. To evaluate the magnitude of these potential biases, the same ship data discussed in the previous paragraph were used (with nutrient concentrations set to zero) to compute carbonate system parameters of interest from the TA$f \mathrm{CO}_{2}$ pair after adding and subtracting the $\pm 2 \sigma$ TA-salinity regression uncertainty $\left(34 \mu \mathrm{mol} \mathrm{kg}{ }^{-1}\right)$ to the TA values. Absolute differences between the resulting values and original estimates from the TA- $f \mathrm{CO}_{2}$ pair (without altering the TA) were then averaged (Table 5). The errors associated with using the Washington TA-salinity relationship are similar in magnitude to those caused by nutrient omission when using the DIC-TA pair and much larger than those resulting from nutrient omission when using the TA- $f \mathrm{CO}_{2}$ pair, excluding for RF. These results suggest that $\Omega_{\mathrm{Ar}}$ is more sensitive to the TA-salinity regression uncertainty than nutrient omission, and $\mathrm{RF}$ is more sensitive to nutrient omission in the $\mathrm{TA}-f \mathrm{CO}_{2}$ pair than uncertainty in TA-salinity regression within Washington waters. Notably, most of the errors are small relative to sensor accuracies and/or natural variability (including for $f \mathrm{CO}_{2}$ and DIC), which will be addressed in Sect. 4.2.

Finally, SOCAT-v4 and mooring SSS data used herein were not rigorously quality controlled beyond the identification of large outliers. Because TA is estimated directly from these salinity observations, we performed a simple evaluation of the TA-salinity regression sensitivity. Modern, generic conductivity sensors can achieve salinity measurements with an accuracy of $\sim 0.02$. To be conservative, we propagate a salinity error ten times this value $( \pm 0.2)$ through the regression calculations. This yields a mean error of $\pm 10 \mu \mathrm{mol} \mathrm{kg}{ }^{-1}$ in TA, which is well within the TA regression $95 \%$ confidence interval of $\pm 34 \mu \mathrm{mol} \mathrm{kg}-1$. In order to exceed the regression uncertainty, a salinity error of $\sim 0.7$, which is 35 times the presumed accuracy of 0.02 , would be required. As a result, salinity measurement errors are likely secondary to uncertainties associated with the regression relationship.

\subsection{New data products of monthly averaged carbonate chemistry}

Discrete sample and SOCAT-v4 datasets (including estimated and calculated values) were combined and gridded to a $0.1^{\circ} \times 0.1^{\circ}$ scale. From here on, this merged product will be referred to as the discrete data product. Figure 2a shows the total number of times that two carbon parameters were available to fully characterize the carbonate system within each $0.1^{\circ} \times 0.1^{\circ}$ grid cell. Monthly means, unique to each year $\left(\mathrm{mm}_{\mathrm{yr}}\right)$, were calculated for each parameter then averaged over the number of years $(n)$ with data to get the overall mean value $(\overline{\mathrm{mm}})$ for each month of the seasonal cycle.

$\overline{\mathrm{mm}}=\frac{\sum_{\mathrm{yr}=1}^{n} \mathrm{~mm}_{\mathrm{yr}}}{n}$ 
Table 5. Errors associated with calculating carbonate system parameters in the absence of nutrient data and when using salinity-based estimates of TA for marine surface waters near Washington. Results for the TA-DIC and TA- $f \mathrm{CO}_{2}$ pairs of input parameters are shown.

\begin{tabular}{lrrrrr}
\hline $\begin{array}{l}\text { Output } \rightarrow \\
\text { Input } \downarrow\end{array}$ & $\mathrm{pH}$ & $\Omega_{\mathrm{Ar}}$ & $\mathrm{RF}$ & $\begin{array}{r}f \mathrm{CO}_{2} \\
(\mu \mathrm{atm})\end{array}$ & $\begin{array}{c}\mathrm{DIC} \\
\left(\mu \mathrm{mol} \mathrm{kg}{ }^{-1}\right)\end{array}$ \\
\hline TA \& DIC (with - without nutrients) & -0.007 & -0.02 & -0.009 & 11 & - \\
TA \& $f \mathrm{CO}_{2}$ (with - without nutrients) & -0.0004 & -0.002 & -0.07 & - & -2 \\
TA \& $f \mathrm{CO}_{2}( \pm 2 \sigma$ on estimated TA) & \pm 0.007 & \pm 0.05 & \pm 0.02 & - & \pm 30 \\
\hline
\end{tabular}

The same approach was applied to the mooring data so that monthly observations from each year were weighted equally, regardless of the number of available samples. Average seasonal cycles of all parameters for each region (discussed below) and mooring are tabulated in Appendices B and C.

Monthly variance values, unique to each year $\left(\mathrm{m} \sigma_{\mathrm{yr}}^{2}\right)$, were calculated for each parameter then averaged over the number of years with data before the square root was taken to determine the mean standard deviation $(\overline{\mathrm{m} \sigma})$ for each month of the seasonal cycle.

$\overline{\mathrm{m} \sigma}=\sqrt{\frac{\sum_{\mathrm{yr}=1}^{n} \mathrm{~m} \sigma_{\mathrm{yr}}^{2}}{n}}$

Figure 3 shows monthly averaged SST data from each annual Cape Elizabeth (CE) mooring deployment ( $\mathrm{mm}_{\mathrm{yr}}$ values) as well as the multi-year average seasonal cycle $(\overline{\mathrm{mm}}$ values). Shading bounds the mean standard deviation (Eq. 2; Fig. 3a) and the standard deviation of monthly mean values (Fig. 3b), as expressed in Eq. (3):

$\sigma=\sqrt{\frac{\sum_{y r=1}^{n}\left(\mathrm{~mm}_{\mathrm{yr}}-\overline{\mathrm{mm}}\right)^{2}}{n-1} .}$

The former (Eq. 2) provides an estimate of the range of variability about the mean that is observed in a given month, while the latter (Eq. 3) provides an estimate of interannual variability in the mean. Both methods deliver equally useful information; however, nearly all of the moored time series are shorter than a decade, which hinders making robust estimates of interannual variability. Thus, standard deviations presented herein (and tabulated in Appendix C) reflect the average range of variability about the mean during each month (i.e., Eq. 2; Fig. 3a).

Figure $2 \mathrm{~b}$ shows the number of months represented in the seasonal cycle estimate for each grid cell, highlighting that all 12 months are rarely resolved within a single grid cell. It is important to note, however, that neighboring grid cells with, for example, 6 months of the year represented may have observations from different months, making it possible to fully resolve the annual cycle by combining the seasonal cycles of neighboring grid cells with similar characteristics. Relying on this approach to accommodate data paucity, salinity and topographic features (e.g., the
Juan de Fuca Canyon and continental shelf) were used to identify eight unique regions (Fig. 2c) in which seasonal cycles from individual grid cells were averaged to create regional estimates. These regions include North Pacific (NP), British Columbia coast (BC), Washington Outer Coast (OC), Columbia River (CR), Strait of Juan de Fuca (JF), Strait of Georgia (SG), Hood Canal (HC), and Puget Sound (PS). Importantly, some of the major physical features that result in regionally distinct characteristics, such as the Columbia and Fraser river plumes and the Juan de Fuca eddy, vary in extent and composition seasonally (e.g., Hickey and Banas, 2008; Evans et al., 2013; Moore-Maley et al., 2018). The nonuniformity of available data in space and time means that these features and their seasonal transitions may not be adequately captured in all grid cells. In addition, the lines between regional boundaries can be blurred by interannual variability that may be inconsistently represented in neighboring grid cells. Thus, the dynamic nature of the coastal zone should be considered when applying the regional seasonal cycles characterized herein, which are presented in a static-boundary framework. Due to the unequal distribution of discrete observations in space and time, monthly mean standard deviations for the regional seasonal cycle estimates do not provide reliable information and are not included in Appendix B.

\section{Results and discussion}

\subsection{Modern seasonal cycles}

Seasonal cycles for the eight regions, derived using measurements from the top $10 \mathrm{~m}$ of the water column, are shown in Fig. 4. A clear pattern of salinity decrease is observed moving from the offshore North Pacific region toward land where rivers contribute freshwater to the marine environment. In particular, the Columbia and Fraser river outflows are evident in the seasonal cycles for the Columbia River and Strait of Georgia regions, with other small rivers exerting a strong influence on the semi-enclosed Hood Canal and Puget Sound domains. SST seasonal cycles are similar in structure across regions, excluding the Strait of Juan de Fuca where vigorous mixing driven by bottom topography results in much cooler surface temperatures than neighboring areas throughout the year (Thomson et al., 2007; Martin and MacCready, 2011; Alford and MacCready, 2014). The mean seasonal cycles for $f \mathrm{CO}_{2}$ and $\mathrm{pH}$ are approximate mirror images within 
(a)

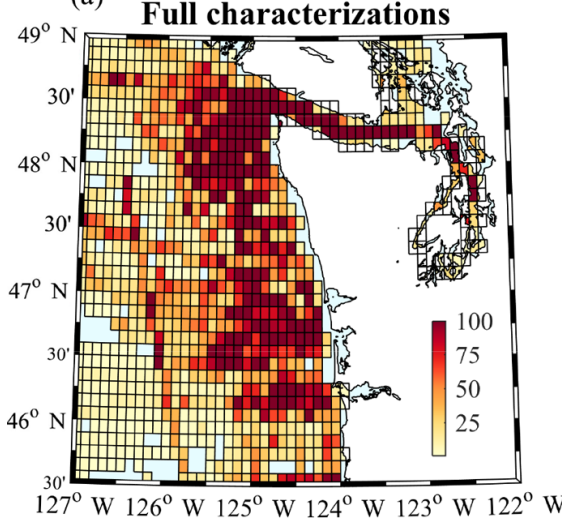

(b)

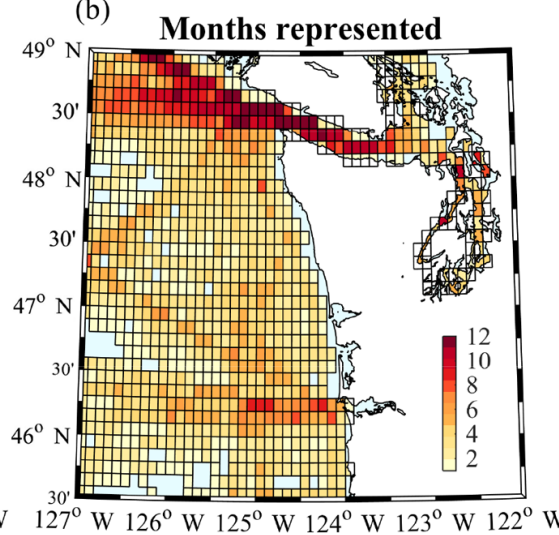

(c)

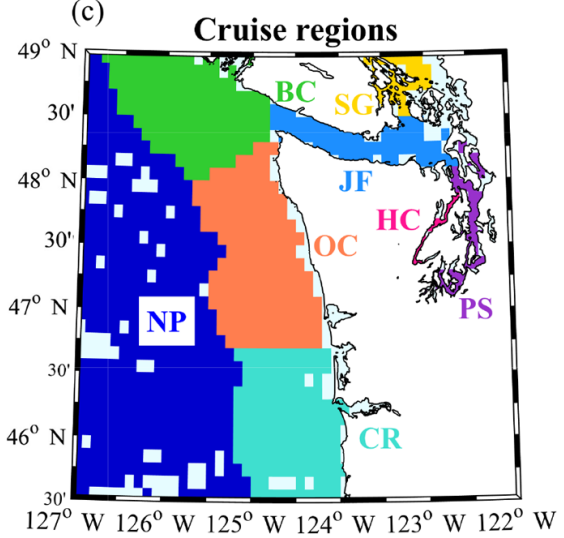

Figure 2. Maps showing (a) the total number of times the carbonate system was fully characterized (two parameters available) in each grid cell, (b) the number of months represented in the seasonal cycle for each grid cell, and (c) the eight unique regions identified, including North Pacific (NP), British Columbia (BC), Outer Coast (OC), Columbia River (CR), Juan de Fuca (JF), Strait of Georgia (SG), Hood Canal (HC), and Puget Sound (PS).
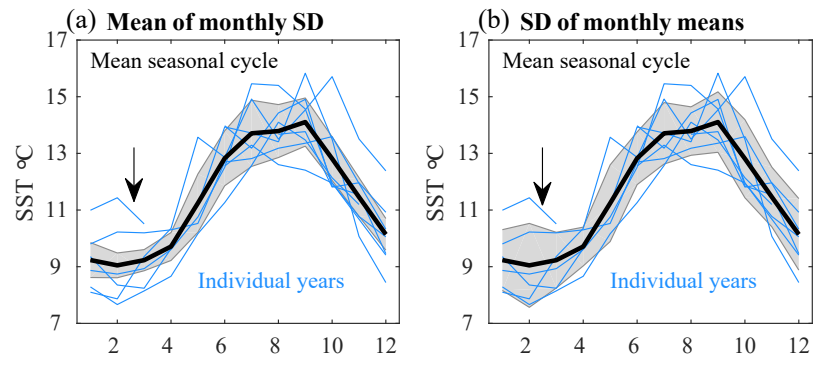

Figure 3. Monthly averaged SST values for each year (2006-2015) of Cape Elizabeth mooring data $\left(\mathrm{mm}_{\mathrm{yr}}\right.$; blue lines) and the average seasonal cycle of SST across all deployments ( $\overline{\mathrm{mm}}$; black line). Blue and black lines are the same in plots (a) and (b). Gray shading represents (a) the mean monthly standard deviation $(\overline{\mathrm{m}} \sigma)$ and (b) the standard deviation of monthly means $(\sigma)$. Black arrows point to a region of notable discrepancy between computations. Here, the average sub-monthly SST variability (a) is much smaller than the range of interannual SST variability (b), indicating that organisms could experience distinct (i.e., non-overlapping) SST conditions during two subsequent Februaries.

each region as a result of the strong negative correlation between these two parameters (Dickson and Riley, 1978). Annual mean $f \mathrm{CO}_{2}$ values increase and $\mathrm{pH}$ values decline when moving from the offshore North Pacific toward the Salish Sea, and the seasonal cycle amplitudes increase for both parameters. In all regions, the lowest $f \mathrm{CO}_{2}$ values emerge during summer and the highest values during winter, which opposes expectations associated with temperature-driven solubility changes (Takahashi et al., 1993). This suggests that physical and biological effects dominate over seasonal solubility changes in all regions (Pelletier et al., 2018), though to varying extents. Due to the logarithmic nature of the $\mathrm{pH}$ scale, declines in the annual mean $\mathrm{pH}$ coupled with increases in the seasonal range of $\mathrm{pH}$ values means that organisms in the Salish Sea (Puget Sound, Hood Canal, Strait of Juan de Fuca, and Strait of Georgia) are exposed to extremely large changes in $\left[\mathrm{H}^{+}\right]$on seasonal timescales. For example, the seasonal range of $\left[\mathrm{H}^{+}\right]$in Hood Canal is $\sim 27$ times larger than in the North Pacific region, which indicates that organisms are living in starkly different chemical regimes across a relatively small spatial domain.

Most regions exhibit moderate seasonal TA variability with the exception of the Strait of Georgia where the Fraser River has a significant impact on the TA. Additionally, the Hood Canal and Puget Sound regions display somewhat erratic seasonal TA variations likely due to sporadic river influences and/or the small number of available samples that are unevenly distributed in space and time (Appendix B). DIC seasonal cycles are similar to TA but with larger amplitudes. Generally, DIC and TA are highest during winter and lowest during summer, with the DIC:TA ratio being lowest during summer. $\Omega_{\mathrm{Ar}}$ is dependent on temperature and the carbonate ion concentration, which is inversely proportional to the DIC : TA ratio. $\Omega_{\text {Ar }}$ closely tracks (DIC:TA) ${ }^{-1}$ changes in all regions, expressing the highest values during summer and the lowest values during winter. If SST is held constant in the CO2SYS calculations of $\Omega_{\mathrm{Ar}}$, the resulting seasonal cycle is altered by $<10 \%$ for all regions. This indicates that local chemistry changes are controlling the $\Omega_{\mathrm{Ar}}$ seasonal cycle throughout the study domain, with temperature contributing minimally. Finally, RF values are elevated during winter and depressed during summer indicating a larger buffer capacity of waters during summer. RF values in the Salish Sea are $\sim 50 \%$ higher than those in coastal regions, particularly during winter, indicating that Salish Sea waters are significantly less efficient at absorbing anthropogenic carbon than open ocean waters at the same latitude. In general, seasonal 
(a) SSS

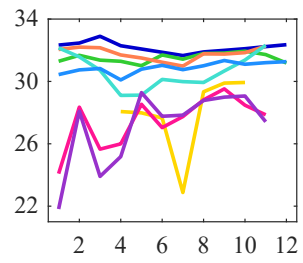

(e)

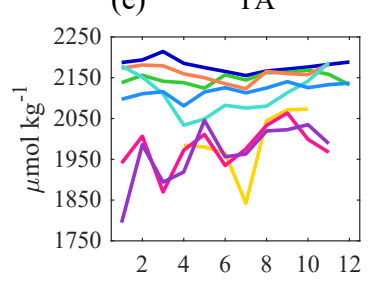

(b)

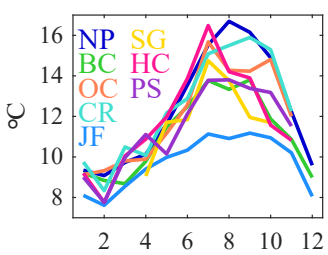

(f)

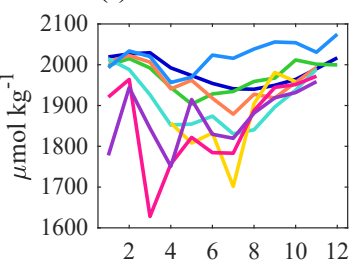

(c)

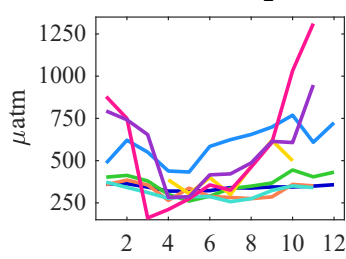

(g)

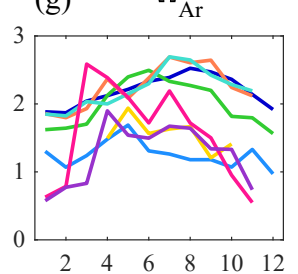

(d)

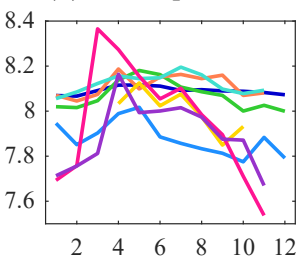

(h)

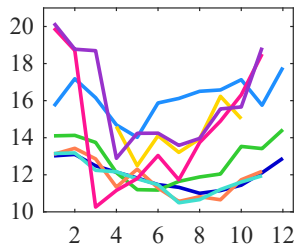

Figure 4. Near-surface (<10 m) seasonal cycles of (a) SSS, (b) SST, (c) $f \mathrm{CO}_{2}$, (d) $\mathrm{pH}_{\mathrm{T}}$, (e) TA, (f) DIC, (g) $\Omega_{\mathrm{Ar}}$, and (h) Revelle factor (RF) for the eight regions shown in Fig. 2c: North Pacific (NP), British Columbia (BC), Outer Coast (OC), Columbia River (CR), Juan de Fuca (JF), Strait of Georgia (SG), Hood Canal (HC), and Puget Sound (PS).

cycle amplitudes are largest within the Salish Sea for all parameters.

Seasonal cycles for the nine moorings, using data collected from $\sim 1 \mathrm{~m}$ depth, are shown in Fig. 5 and generally follow the same pattern as the eight regions. SSS decreases when moving inland from the outer coast toward Puget Sound. SST cycles are similar across moorings, with larger amplitudes found in shallower basins, such as at the Bellingham Bay and Carr Inlet moorings, as well as the moorings in Hood Canal where vertical mixing is weaker than in other parts of Puget Sound (Newton et al., 2003). $\mathrm{pH}$ and $f \mathrm{CO}_{2}$ display opposing seasonal cycles and TA follows the seasonality of salinity, as expected, exhibiting lower values during spring and summer and higher values during fall and winter. DIC displays more pronounced seasonal cycles with the lowest values in summer and highest values in winter. As seen for the regional discrete sample data, $\Omega_{\mathrm{Ar}}$ is highest during summer and lowest during winter following its inverse relationship with DIC: TA. Finally, RF values are lowest during summer and highest during winter, with the largest annual mean values in the Salish Sea. In general, seasonal cycle amplitudes for all parameters are higher in the Salish Sea than on the outer coast, similar to what was found for the regional evaluations.

A shared feature of the region and mooring seasonal cycle results is the seasonal evolution of offshore-onshore gradients in numerous parameters. For example, most regions and moorings exhibit similar winter SST values; however, large gradients in SST are found between sites during summer. Alternatively, $\mathrm{pH}, \Omega_{\mathrm{Ar}}$, and $f \mathrm{CO}_{2}$ are most similar across sites during summer, with the largest gradients found during winter. These findings suggest that seasonal resolution is needed to accurately describe the spatial pattern of chemical gradients in the US Pacific Northwest, particularly since different parameters exhibit maximum gradients at dissimilar times of the year. Consistency between the large-scale seasonal cycle patterns derived from the nine moorings and eight unique regions is somewhat surprising due to differences in the sampling depth, with the moorings sampling the top $\sim 1 \mathrm{~m}$ of the water column and regional seasonal cycles derived from samples within the top $10 \mathrm{~m}$. Since deeper waters are generally cooler and have higher salinity, $f \mathrm{CO}_{2}$, TA, and DIC values, this implies that seasonal forcing overwhelms any influence of stratification, yielding the broad agreement between region and mooring seasonal cycles.

To more directly compare results from the regions and moorings and evaluate large-scale patterns of variability, we focus on seasonal cycles from the Washington Coast, Puget Sound, and Hood Canal domains. The left column of Fig. 6 shows mean seasonal cycles from the Cape Elizabeth and Chá bă moorings and the Columbia River and Outer Coast regions. The two moorings lie within the Outer Coast region and display similar SSS and SST seasonal cycles, suggesting that large-scale rather than local physical processes dominate the seasonal cycles at both locations. However, there are notable differences in the seasonal cycles of carbonate system variables between moorings, which indicates that carbonate chemistry on the Washington coast is somewhat heterogeneous and cannot be adequately characterized with observations from a single mooring. In contrast to the moorings and Outer Coast domain, the Columbia River region exhibits a SSS and TA depression during spring and early summer in concert with the maximum in Columbia River discharge. The fresh water plume is often advected southward due to seasonal winds and does not greatly influence salinity in the neighboring Outer Coast region or at the Cape Elizabeth mooring during the summer months. 
(a)

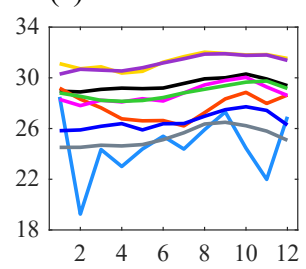

(e)

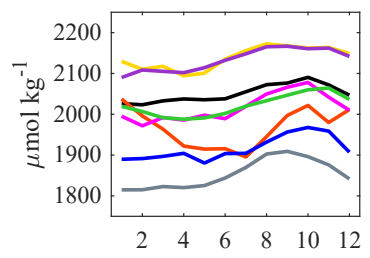

(b)

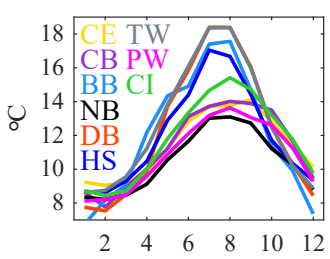

(f)

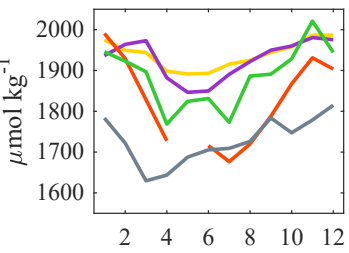

(c)

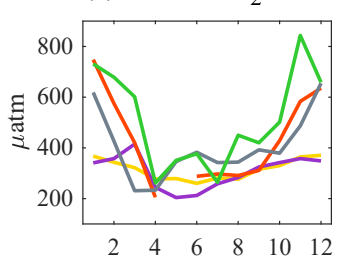

(g)

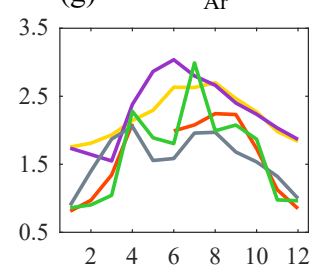

(d)

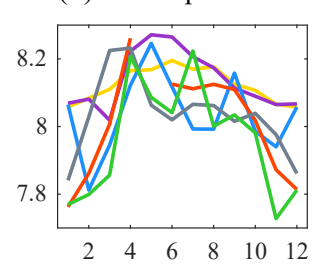

(h)

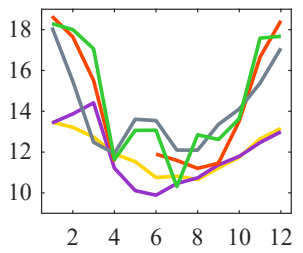

Figure 5. Near-surface ( $\sim 1 \mathrm{~m}$ ) seasonal cycles of (a) SSS, (b) SST, (c) $f \mathrm{CO}_{2}$, (d) $\mathrm{pH}_{\mathrm{T}}$, (e) TA, (f) DIC, (g) $\Omega_{\mathrm{Ar}}$, and (h) Revelle factor (RF) for the nine moorings shown in Fig. 1a: Cape Elizabeth (CE), Chá bă (CB), Carr Inlet (CI), Dabob Bay (DB), Twanoh (TW), Hoodsport (HS), Point Wells (PW), North Buoy (NB), and Bellingham Bay (BB).

Gray shading around the Cape Elizabeth mooring seasonal cycles reflects the average range of variability about the monthly mean (Eq. 2; $\overline{\mathrm{m} \sigma}$ ). Sensors on the Cape Elizabeth and Chá bă moorings collect samples every $3 \mathrm{~h}$, which means that 1 year of data equates to $\sim 3000$ observations, or $\sim 250$ observations per month (though there are occasional gaps in the time series; Fig. 1b). With multiple years of observations (Appendix B), data from these moorings provide robust constraints on the average range of sub-monthly variability. The region-based seasonal cycles fall within the $\pm 1 \sigma$ envelope of the mooring-based seasonal cycles for most carbonate system parameters, suggesting general agreement across data products. This finding underlines that seasonal variations outcompete the influence of vertical gradients in the upper water column associated with stratification, which would work to create discrepancies between the data products due to the unique depth ranges of data contributing to the mooring $(\sim 1 \mathrm{~m})$ and regional $(\leq 10 \mathrm{~m})$ seasonal cycle assessments.

Moving inland, the middle column of Fig. 6 shows the Carr Inlet and Point Wells moorings and the Puget Sound region. The two moorings display similar SSS and TA seasonal cycles in terms of magnitude and timing, and general agreement in SST with a larger amplitude seasonal cycle at the Carr Inlet mooring due to more stratified conditions relative to the well-mixed Point Wells site in the main basin of Puget Sound. The Puget Sound region generally follows the mooring SSS and SST results, with some erratic variations likely caused by the much smaller number of observations (Appendix B). Carbonate chemistry seasonal cycles from the Carr Inlet mooring and Puget Sound region are similar in pattern but are offset due to the lower TA values found throughout Puget Sound for nearly all months. Differences in the timing of seasonal agreement between the carbon variables at Carr Inlet and Puget Sound may be attributable to stratification and sampling depth; however, it is also important to note that the carbonate variables from Carr Inlet are based on only $\sim 1.5$ years of observations.

Finally, the right column of Fig. 6 shows results from the Twanoh, Dabob Bay, and Hoodsport moorings as well as the Hood Canal region. There are significant differences in SSS across sites, while SST seasonal cycles are similar for Twanoh and Dabob Bay as well as for Hoodsport and the Hood Canal region. Seasonal SSS variations at Twanoh and Hoodsport are similar in timing and amplitude, but SSS is depressed at Twanoh due to its proximity to the Skokomish River. This influence is muted at the Hoodsport mooring and even more so at the Dabob Bay mooring (and correspondingly evident in TA), which is located much farther north and outside of the main channel. The moorings, thus, depict a range of diverse physical conditions within Hood Canal that depend on the sampling location. This is relevant because seasonal cycles for the Hood Canal region were determined using far fewer discrete samples that were collected across the entire domain (Appendix B), and thus blend all of the nuanced environments within the canal. Though observations are not presently available to show the range of variability across the Puget Sound region, this issue is likely also important when interpreting seasonal cycles from that domain.

The seasonal cycles for carbonate system variables are unique across sites within Hood Canal with somewhat better agreement found between the Twanoh and Dabob Bay moorings. The pycnocline in Hood Canal is typically strong and often located at $\sim 5-8 \mathrm{~m}$. Thus, the $10 \mathrm{~m}$ depth-integrated water samples used for the regional assessment would include colder, saltier, and more carbon-rich waters than the surface moorings. This influence can be seen in SSS and DIC where the Hood Canal region displays higher values than the 

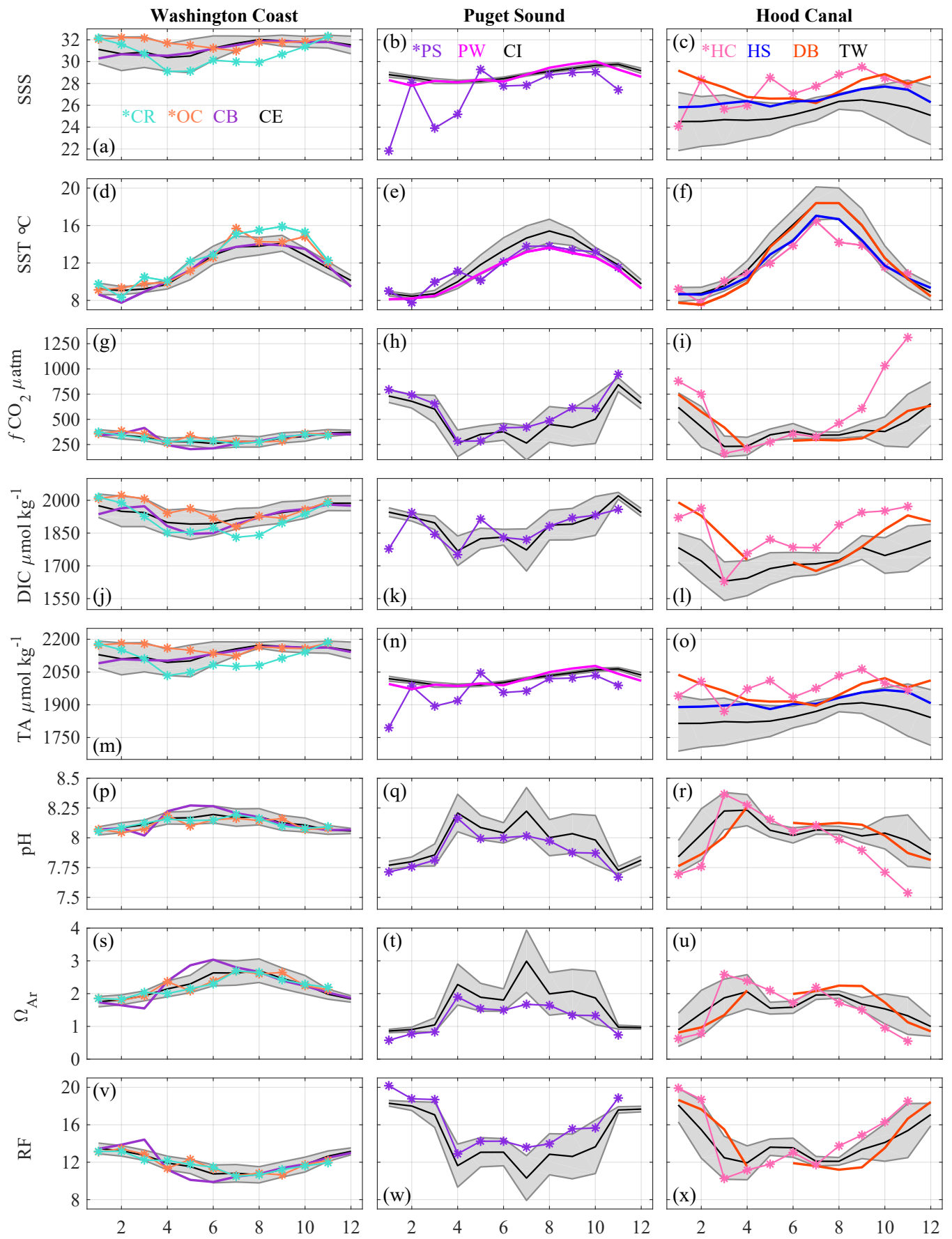

Figure 6. Seasonal cycles of (a)-(c) SSS, (d)-(f) SST, (g)-(i) $f \mathrm{CO}_{2}$, (j)-(l) DIC, (m)-(o) TA, (p)-(r) pH $\mathrm{H}_{\mathrm{T}}$, (s) $-(\mathbf{u}) \Omega_{\mathrm{Ar}}$, and (v)-(x) $\mathrm{RF}$ for regions and moorings located along the outer Washington Coast, in Puget Sound, and in Hood Canal. Asterisks are used for the regions. Black lines with gray shading highlight data from one mooring within each domain (see figure keys in subplots a to c). Gray shading shows the average range of variability about the mean during each month (i.e., average standard deviation across years derived from variance estimates). See also Appendix D figures.

moorings during almost all months. This is particularly notable for SSS since the mooring estimates come from averaging the top $3 \mathrm{~m}$ of profiling mooring observations. Thus, the region and mooring SSS (and SST) discrepancies would likely be larger if the mooring values actually came from the top $1 \mathrm{~m}$ of water, where the $f \mathrm{CO}_{2}$ measurements are made. This is supported by the extremely high $f \mathrm{CO}_{2}$ and low $\mathrm{pH}$ values observed in the Hood Canal region during winter that 
significantly exceed what is found at the moorings. Better agreement in $f \mathrm{CO}_{2}$ and $\mathrm{pH}$ exists across sites during summer, and there are fewer discrepancies for $\Omega_{\mathrm{Ar}}$ and RF at all locations throughout the year due to the large dependence of both parameters on the DIC : TA ratio, which is similar across sites.

Having discussed important nuances between the region and mooring seasonal cycles within these domains, it is important to also consider the large-scale gradients in carbonate chemistry across the domains. Taking a broader view of Fig. 6, a greater environmental context is gained by comparing results from the open North Pacific Ocean and the Salish Sea. The large decline in SSS and increase in SST as waters become more stratified and heavily influenced by rivers when moving toward land greatly outcompetes any small differences found among sites within a given domain. There is an accompanying pattern of DIC decline along this path; however, TA exhibits even larger declines, resulting in elevated DIC:TA ratios and more poorly buffered waters (higher RF values) within the Salish Sea. This leads to much higher $f \mathrm{CO}_{2}$ values and lower $\mathrm{pH}$ and $\Omega_{\mathrm{Ar}}$ values in Hood Canal and Puget Sound than on the outer Washington coast. Since the North Pacific Ocean is the sole source of marine water to the Salish Sea, elevated carbon content within the Salish Sea reflects longer retention times and potentially intensified carbon cycling due to local nutrient and carbon dioxide pollution (Feely et al., 2010; Pelletier et al., 2017).

In addition to gradients in annual mean values of carbonate system parameters, there is a significant increase in the amplitude of seasonal cycles and in the range of submonthly variability moving landward. Unexpectedly, the seasonal evolution of sub-monthly variability is unique to different domains. For example, at the Twanoh mooring $f \mathrm{CO}_{2}$, $\mathrm{pH}$, and $\Omega_{\mathrm{Ar}}$ vary significantly more about the mean value during winter than during summer; however, at Carr Inlet and Cape Elizabeth, the opposite is true. This kind of insight, which emerges from sustained observing, provides precisely the type of information necessary to streamline OA monitoring, adaption, and research. For example, understanding how natural variability amplifies and attenuates throughout the year could improve our interpretations of sparse data, since samples collected during seasons with low sub-monthly variability may better represent the monthly mean condition. Additionally, the season exhibiting the lowest range of variability for a given parameter will likely be first to exit the envelope of natural variability as anthropogenic carbon accumulates (Hauri et al., 2013; Sutton et al., 2016b). This nuanced information may be useful for determining when organisms will begin to experience persistent anomalous conditions and for designing experiments that accurately reflect nonstationarity in natural variability throughout the year.

\subsection{Important limitations to consider}

Although the average seasonal cycles herein may help to inform OA monitoring and research conducted throughout the region, there are important limitations that must be acknowledged. The region-specific seasonal cycles are meant to provide a large-scale environmental context and an understanding of how the carbonate system varies across the broader domain. The moorings fill in temporal observing gaps and give robust statistical estimates of mean conditions at specific locations, as well as the average variability around those means. General agreement among the region and mooring seasonal cycles lends confidence to the results but is not necessarily expected due to data paucity coupled with natural temporal variability and spatial heterogeneity within the various regions (e.g., Fig. 6). Opportunities for discrepancy were especially evident in the more stratified domains, such as Hood Canal and Puget Sound, due to differences in sampling depth for the various datasets. While seasonal forcing appears to dominate over stratification and vertical gradient issues in all domains, prior work has clearly shown that surface conditions do not reflect bottom water conditions (Feely et al., 2010; Pelletier et al., 2017). General agreement between data products is likely due to all depths residing within the euphotic zone such that vertical gradients are minimized relative to those found throughout the full water column.

A key challenge in developing seasonal cycle estimates for the smaller regional domains (e.g., Hood Canal and Puget Sound) is the dearth of data that renders these seasonal cycles more susceptible to biases that may result from nonhomogenous conditions (e.g., proximity to rivers), interannual variability, or anomalous events (e.g., storms). As discrete observations amass, this issue will attenuate, but at present is something that needs to be considered when using the information provided herein. Additionally, regional seasonal cycles were evaluated using rigid domain boundaries, which we know to be dynamic in reality (e.g., Hickey and Banas, 2008). Thus, caution should be used when relying on our estimates to evaluate samples collected near one of the boundaries. The use of a static regional TA-salinity relationship also has important implications for how carbonate system seasonal cycles can be interpreted. The TA-salinity relationship homogenizes the influence of freshwater alkalinity input (organic and inorganic) from numerous rivers in the region, which can have distinct chemical characteristics that vary seasonally (e.g., Evans et al., 2013; MooreMaley et al., 2018). As a result, the regression may not work perfectly near a specific river mouth. In these cases (e.g., the Twanoh mooring), the TA estimates may be biased and the bias may change seasonally. Importantly, Table 5 displays how these biases can propagate to other carbonate system variables. For all parameters, these errors are significantly smaller than the seasonal cycle amplitudes and, in most cases, are smaller than the $\pm 1 \sigma$ values from the moor- 
ings (Appendix B). This is also true of the in situ measurement errors discussed throughout Sect. 2.

\subsection{Understanding what the data do and do not reveal}

Characterizing average seasonal cycles throughout the study domain reveals important insights about how different types of observations can be used to better understand the dynamic coastal region. Discrete measurements made sporadically over space and time can be challenging to interpret without a vast number of data points, which are both cost- and timeintensive to collect. This limitation arises from spatial heterogeneity and the range of temporal scales over which variability can occur in the coastal zone (e.g., $<$ days to $>$ decades). Discrete observations provide a snapshot in time that may or may not represent the mean condition. Even with multiple years of observations, and no interannual variability, the true mean can be elusive due to sub-monthly variations. What discrete observations do extremely well is unveil the connectivity of spatial domains by sampling across regions over a fixed period of time (e.g., research cruise). This too has uncertainty resulting from environmental heterogeneity and chemical gradients that are nonstationary over time but is at present the most effective and efficient method of making high-quality dual-parameter carbon observations across a wide spatial area.

Moorings provide something altogether different. Sustained, high-frequency observations fill in temporal uncertainties, integrating over (often) unknown spatial scales that vary with tidal cycles, surface currents, and depth, allowing for robust determination of the mean condition and the average variability about the mean within the represented domain. This type of information lends context to discrete samples by providing bounds within which discrete samples may be expected to reside. Figure 7, for example, shows the monthly mean $f \mathrm{CO}_{2}$ seasonal cycle from the Cape Elizabeth mooring as well as the same data shifted upward by $50 \mu \mathrm{atm}$, which is meant to represent an anomalous year, where the range of sub-monthly variability (shading) is identical for each year. Two discrete $f \mathrm{CO}_{2}$ samples collected during one "normal" and one "anomalous" June could span over $100 \mu \mathrm{atm}$, hampering determination of which sample best reflects the mean condition. Mooring observations collected over the same 2 years would give an average seasonal cycle that falls in-between the two lines shown in Fig. 7, and the discrete samples would thus lie outside of the associated $\pm 1 \sigma$ window. This would make it tempting to conclude that the discrete samples are outliers when the data actually indicate that one of the sampling years was anomalous. The true climatology would eventually emerge with additional years of observations. Thus, firm conclusions about what is or is not an anomaly or outlier may be extremely challenging to decipher without a sustained time series and information about the magnitude of sub-monthly variability.

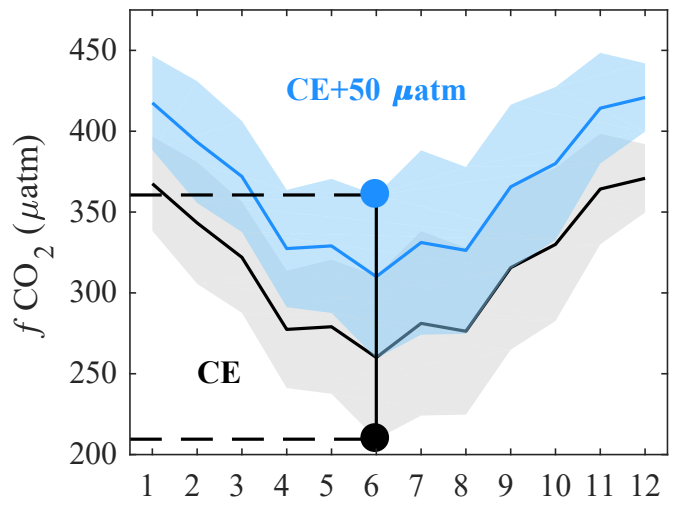

Figure 7. Schematic showing the Cape Elizabeth (CE) mooring monthly mean $f \mathrm{CO}_{2}$ seasonal cycle (black) and the seasonal cycle $+50 \mu$ atm (blue), which is meant to reflect an anomalous year. Black and blue shading are identical in magnitude and show the mean standard deviation $(\overline{\mathrm{m} \sigma})$. The filled circles show two hypothetical discrete samples collected during June of each year.

To summarize, the array of time and space scales over which chemical variability occurs in US West Coast and adjacent waters hinders our ability to adequately describe the coastal system without the dual effort of ship-based and moored observations that provide complementary information. The seasonal cycles presented herein are an example of what can be achieved from such efforts and serve as a starting point from which strategic improvements to observational networks can be made.

\section{Data availability}

All data used in this analysis can be accessed using the DOIs listed in Tables 1 and 3 .

\section{Conclusions}

Quantifying modern human-induced changes in surface ocean chemistry requires a baseline from which to assess alterations. These baselines often do not exist in coastal regions where large-magnitude and high-frequency natural oscillations can overwhelm the secular anthropogenic signal. This inhibits our understanding of how coastal environments are changing and will continue to do so until these domains are adequately characterized. In an effort to galvanize baseline development for seawater parameters relevant to the study of ocean acidification, we have compiled $\sim 100000$ in situ carbonate system observations from marine surface waters near Washington State to characterize carbonate system variability throughout the region. By merging $f \mathrm{CO}_{2}$ observations from the SOCAT-v4 database with dissolved inorganic carbon (DIC), total alkalinity (TA), and $\mathrm{pH}_{\mathrm{T}}$ measurements made during discrete sampling efforts, we have estimated the average seasonal cycles of numerous carbonate system 
parameters in marine surface waters from eight distinct regions within the US Pacific Northwest. Agreement between these regional estimates and the average seasonal cycles determined at nine surface moorings throughout Washington State coastal waters indicates a coherent large-scale gradient in carbonate chemistry from the open North Pacific Ocean into the Salish Sea that is seasonally variable. Near-surface salinity, DIC, TA, aragonite saturation state, and $\mathrm{pH}$ decline significantly along this path. Larger declines in TA relative to DIC lead to elevated $f \mathrm{CO}_{2}$ and Revelle factor values within the Salish Sea, indicating a lower capacity of these inland waters to absorb anthropogenic carbon than offshore waters at the same latitude. These large-scale gradients persist throughout the year but vary seasonally in magnitude with unique variables expressing larger gradients during different seasons. For all carbonate system parameters, the seasonal cycle amplitudes and ranges of sub-monthly variability are larger within the Salish Sea, indicating that organisms living in the US Pacific Northwest experience starkly different chemical environments across the study domain.
In addition to providing environmental context, this analysis reveals important insights about the extreme care required to accurately interpret spatially and temporally nonuniform observations from the coastal zone. Spatial heterogeneity was discovered within all regional domains evaluated, indicating that chemical conditions, even in semi-enclosed domains, cannot be adequately characterized using observations from a single mooring. Additionally, the wide range of sub-monthly variability found at the mooring sites suggests that it may be difficult to determine what is and is not an outlier in a discrete dataset, particularly in the context of interannual variability. By pairing multiple types of datasets (discrete, underway, and sustained time series) our ability to interpret complex coastal environments can be enhanced by more than what is achievable from any one observing approach. It is our intent that the insights gained from the seasonal cycle characterizations herein help to guide strategic monitoring, management, and scientific inquiry that leads to improved baseline development and water quality assessment in Washington State. 


\section{Appendix A}

Table A1. Discrete datasets incorporated into the analysis. The observing period and the number of phosphate, silicate, SSS, and SST observations for each cruise are provided. Data DOIs matching those in Table 1 are also listed. Phosphate and silicate samples were analyzed following standard protocols (UNESCO, 1994) during all cruises.

\begin{tabular}{|c|c|c|c|c|c|c|}
\hline Nutrients & $\begin{array}{l}\text { Obs. } \\
\text { Period }\end{array}$ & $\begin{array}{r}\text { Phosphate } \\
\text { Obs. }\end{array}$ & $\begin{array}{r}\text { Silicate } \\
\text { Obs. }\end{array}$ & $\begin{array}{l}\text { SSS } \\
\text { Obs. }\end{array}$ & $\begin{array}{l}\text { SST } \\
\text { Obs. }\end{array}$ & Data DOI \\
\hline SOCAT-v $4^{\mathrm{a}}$ & 1970-2015 & 0 & 0 & 52528 & 57422 & https://doi.pangaea.de/10.1594/PANGAEA.866856 \\
\hline NOAA WCOA & $05 / 2007$ & 11 & 11 & 11 & 11 & https://doi.org/10.3334/CDIAC/otg.CLIVAR_NACP_West_Coast_Cruise_2007 \\
\hline UW PRISM ${ }^{b}$ & $02 / 2008$ & 74 & 78 & 80 & 80 & https://doi.org/10.5281/zenodo.1184657 \\
\hline UW PRISM/EPA ${ }^{b}$ & $08 / 2008$ & 105 & 105 & 122 & 122 & https://doi.org/10.5281/zenodo.1184657 \\
\hline $\mathrm{PacOOS}^{\mathrm{b}}$ & $08 / 2009$ & 8 & 8 & 8 & 8 & https://doi.org/10.5281/zenodo.1184657 \\
\hline UW PRISM $^{\mathrm{b}}$ & $09 / 2009$ & 38 & 38 & 38 & 38 & https://doi.org/10.5281/zenodo.1184657 \\
\hline $\mathrm{PaCOOS}^{\mathrm{b}}$ & $05 / 2010$ & 13 & 13 & 13 & 13 & https://doi.org/10.5281/zenodo.1184657 \\
\hline $\mathrm{PacOOS}^{\mathrm{b}}$ & $08 / 2010$ & 22 & 22 & 22 & 22 & https://doi.org/10.5281/zenodo.1184657 \\
\hline UW PRISM ${ }^{b}$ & $11 / 2010$ & 39 & 39 & 40 & 40 & https://doi.org/10.5281/zenodo.1184657 \\
\hline UW/Chá bă ${ }^{b}$ & $05 / 2011$ & 0 & 0 & 1 & 1 & https://doi.org/10.5281/zenodo.1184657 \\
\hline NOAA WCOA & 08/2011 & 11 & 11 & 37 & 37 & https://doi.org/10.7289/V5JQ0XZ1 \\
\hline UW PRISM ${ }^{b}$ & $10 / 2011$ & 38 & 38 & 60 & 60 & https://doi.org/10.5281/zenodo.1184657 \\
\hline UW/NANOOS ${ }^{b}$ & $05 / 2012$ & 0 & 0 & 4 & 4 & https://doi.org/10.5281/zenodo.1184657 \\
\hline NOAA WCOA & $09 / 2012$ & 40 & 43 & 43 & 43 & https://data.nodc.noaa.gov/cgi-bin/iso?id=gov.noaa.nodc:0157445 \\
\hline UW/Chá bă & $01 / 2013$ & 0 & 0 & 2 & 2 & https://doi.org/10.5281/zenodo.1184657 \\
\hline UW/NANOOS ${ }^{b}$ & $04 / 2013$ & 1 & 1 & 19 & 19 & https://doi.org/10.5281/zenodo.1184657 \\
\hline NOAA WCOA & $08 / 2013$ & 59 & 59 & 59 & 59 & https://doi.org/10.7289/V5C53HXP \\
\hline UW/NANOOS ${ }^{\mathrm{b}}$ & $09 / 2013$ & 14 & 14 & 19 & 19 & https://doi.org/10.5281/zenodo.1184657 \\
\hline UW/NANOOS ${ }^{b}$ & $06 / 2014$ & 10 & 10 & 10 & 10 & https://doi.org/10.5281/zenodo.1184657 \\
\hline ECY & $06 / 2014$ & 8 & 8 & 17 & 17 & https://doi.org/10.5281/zenodo.1184657 \\
\hline WOAC $^{b}$ & $07 / 2014$ & 61 & 61 & 68 & 68 & https://doi.org/10.5281/zenodo.1184657 \\
\hline ECY & 07/2014 & 0 & 0 & 12 & 12 & https://doi.org/10.5281/zenodo.1184657 \\
\hline ECY & 08/2014 & 0 & 0 & 18 & 18 & https://doi.org/10.5281/zenodo.1184657 \\
\hline WOAC $^{\mathrm{b}}$ & $09 / 2014$ & 64 & 64 & 64 & 64 & https://doi.org/10.5281/zenodo.1184657 \\
\hline ECY & $09 / 2014$ & 0 & 0 & 14 & 14 & https://doi.org/10.5281/zenodo.1184657 \\
\hline UW/Chá bă ${ }^{b}$ & $10 / 2014$ & 19 & 19 & 19 & 19 & https://doi.org/10.5281/zenodo.1184657 \\
\hline ECY & $10 / 2014$ & 0 & 0 & 9 & 9 & https://doi.org/10.5281/zenodo.1184657 \\
\hline ECY & $11 / 2014$ & 6 & 6 & 9 & 9 & https://doi.org/10.5281/zenodo.1184657 \\
\hline ECY & $01 / 2015$ & 13 & 12 & 13 & 13 & https://doi.org/10.5281/zenodo.1184657 \\
\hline ECY & $02 / 2015$ & 11 & 11 & 15 & 15 & https://doi.org/10.5281/zenodo.1184657 \\
\hline ECY & $03 / 2015$ & 8 & 8 & 20 & 20 & https://doi.org/10.5281/zenodo.1184657 \\
\hline ECY & $04 / 2015$ & 5 & 5 & 15 & 15 & https://doi.org/10.5281/zenodo.1184657 \\
\hline ECY & $05 / 2015$ & 2 & 2 & 6 & 6 & https://doi.org/10.5281/zenodo.1184657 \\
\hline Total & & 680 & 686 & 53415 & 58309 & \\
\hline
\end{tabular}

${ }^{\mathrm{a}}$ The coastal subset of SOCAT-v4 data can be easily accessed here: https://www.socat.info/index.php/version- $4 / .{ }^{\mathrm{b}}$ Full dataset in preparation for submission to a long-term data repository. 
Appendix B

Table B1. Average monthly SSS seasonal cycles for the eight unique regions. The total number of observations (no. of Obs.) contributing to the monthly average estimate is included.

\begin{tabular}{lrrrrrrrrrrrr}
\hline SSS & Jan & Feb & Mar & Apr & May & Jun & Jul & Aug & Sep & Oct & Nov & Dec \\
\hline North Pacific (NP) & 32.3 & 32.5 & 32.9 & 32.3 & 32.1 & 31.9 & 31.7 & 31.9 & 32.0 & 32.1 & 32.2 & 32.4 \\
no. of Obs. & 163 & 439 & 250 & 66 & 305 & 2791 & 4024 & 1812 & 504 & 88 & 109 & 29 \\
British Columbia (BC) & 31.3 & 31.7 & 31.4 & 31.3 & 31.0 & 31.7 & 31.4 & 31.8 & 31.8 & 31.9 & 31.7 & 31.2 \\
no. of Obs. & 162 & 647 & 205 & 160 & 452 & 1107 & 8067 & 1735 & 250 & 229 & 110 & 100 \\
Outer Coast (OC) & 32.1 & 32.2 & 32.2 & 31.7 & 31.5 & 31.2 & 31.0 & 31.8 & 31.8 & 31.8 & 32.3 & \\
no. of Obs. & 57 & 65 & 170 & 7 & 34 & 1700 & 6969 & 5585 & 749 & 5 & 13 & \\
Columbia River (CR) & 32.1 & 31.6 & 30.7 & 29.1 & 29.1 & 30.1 & 30.0 & 29.9 & 30.7 & 31.4 & 32.3 & \\
no. of Obs. & 120 & 19 & 98 & 23 & 135 & 3456 & 1545 & 3059 & 719 & 24 & 46 & \\
Juan de Fuca (JF) & 30.4 & 30.7 & 30.8 & 30.1 & 30.8 & 31.0 & 30.8 & 31.0 & 31.3 & 31.1 & 31.2 & 31.3 \\
no. of Obs. & 68 & 2099 & 172 & 48 & 274 & 627 & 2046 & 814 & 152 & 44 & 43 & 40 \\
Strait of Georgia (SG) & & 28.7 & & 28.1 & 28.0 & 27.7 & 22.9 & 29.3 & 29.9 & 29.9 & & \\
no. of Obs. & & 192 & & 5 & 58 & 32 & 5 & 35 & 6 & 1 & & \\
Hood Canal (HC) & 24.1 & 28.3 & 25.7 & 26.0 & 28.5 & 27.0 & 27.7 & 28.8 & 29.5 & 28.5 & 27.9 & \\
no. of Obs. & 1 & 24 & 3 & 3 & 3 & 3 & 27 & 28 & 6 & 71 & 25 & \\
Puget Sound (PS) & 21.8 & 28.1 & 23.9 & 25.2 & 29.3 & 27.8 & 27.8 & 28.8 & 29.0 & 29.1 & 27.4 & \\
no. of Obs. & 12 & 57 & 17 & 12 & 35 & 93 & 287 & 257 & 32 & 49 & 15 & \\
\hline
\end{tabular}

Table B2. Average monthly SST seasonal cycles for the eight unique regions. The total number of observations (no. of Obs.) contributing to the monthly average estimate is included.

\begin{tabular}{lrrrrrrrrrrrr}
\hline SST $\left({ }^{\circ}\right.$ C) & Jan & Feb & Mar & Apr & May & Jun & Jul & Aug & Sep & Oct & Nov & Dec \\
\hline North Pacific (NP) & 9.3 & 9.1 & 9.7 & 10.1 & 11.6 & 13.5 & 15.5 & 16.7 & 16.1 & 14.9 & 12.2 & 9.6 \\
no. of Obs. & 163 & 446 & 250 & 66 & 364 & 2791 & 4026 & 1922 & 504 & 88 & 109 & 29 \\
British Columbia (BC) & 9.2 & 8.8 & 8.7 & 9.8 & 11.5 & 12.5 & 13.8 & 13.3 & 13.8 & 11.9 & 10.9 & 9.0 \\
no. of Obs. & 166 & 644 & 205 & 160 & 567 & 1102 & 8078 & 1938 & 250 & 229 & 110 & 100 \\
Outer Coast (OC) & 9.1 & 9.3 & 9.8 & 9.9 & 11.2 & 12.6 & 15.7 & 14.3 & 14.2 & 14.8 & 12.0 & \\
no. of Obs. & 57 & 65 & 170 & 7 & 34 & 1700 & 6969 & 6301 & 750 & 5 & 13 & \\
Columbia River (CR) & 9.7 & 8.3 & 10.5 & 10.1 & 12.2 & 12.9 & 15.1 & 15.5 & 15.9 & 15.3 & 12.3 & \\
no. of Obs. & 120 & 19 & 98 & 23 & 135 & 3456 & 1545 & 3614 & 719 & 24 & 46 & \\
Juan de Fuca (JF) & 8.1 & 7.6 & 8.5 & 9.4 & 10.0 & 10.3 & 11.1 & 10.9 & 11.2 & 10.9 & 10.2 & 8.1 \\
no. of Obs. & 71 & 2108 & 172 & 48 & 378 & 628 & 1953 & 816 & 153 & 44 & 43 & 39 \\
Strait of Georgia (SG) & & 7.2 & & 9.1 & 11.7 & 11.8 & 14.7 & 13.8 & 12.0 & 11.7 & & \\
no. of Obs. & & 197 & & 5 & 59 & 33 & 5 & 35 & 6 & 1 & & \\
Hood Canal (HC) & 9.2 & 7.8 & 10.1 & 10.9 & 12.0 & 13.9 & 16.5 & 14.2 & 13.9 & 11.6 & 10.8 & \\
no. of Obs. & 1 & 24 & 3 & 3 & 3 & 3 & 27 & 28 & 6 & 71 & 25 & \\
Puget Sound (PS) & 9.0 & 7.8 & 10.0 & 11.1 & 10.1 & 12.1 & 13.8 & 13.8 & 13.4 & 13.2 & 11.5 & \\
no. of Obs. & 12 & 57 & 17 & 12 & 35 & 93 & 298 & 257 & 32 & 49 & 15 & \\
\hline
\end{tabular}


Table B3. Average monthly TA seasonal cycles for the eight unique regions. The total number of observations (no. of Obs.) contributing to the monthly average estimate is included.

\begin{tabular}{|c|c|c|c|c|c|c|c|c|c|c|c|c|}
\hline $\mathrm{TA}\left(\mu \mathrm{mol} \mathrm{kg}{ }^{-1}\right)$ & Jan & $\mathrm{Feb}$ & Mar & Apr & May & Jun & Jul & Aug & Sep & Oct & Nov & Dec \\
\hline North Pacific (NP) & 2187 & 2194 & 2214 & 2185 & 2175 & 2165 & 2155 & 2167 & 2171 & 2176 & 2183 & 2189 \\
\hline no. of Obs. & 163 & 439 & 250 & 66 & 305 & 2791 & 4024 & 1812 & 504 & 88 & 109 & 29 \\
\hline British Columbia (BC) & 2138 & 2156 & 2141 & 2138 & 2124 & 2157 & 2144 & 2163 & 2163 & 2169 & 2158 & 2133 \\
\hline no. of Obs. & 162 & 647 & 205 & 160 & 452 & 1107 & 8067 & 1735 & 250 & 229 & 110 & 100 \\
\hline Outer Coast (OC) & 2173 & 2181 & 2179 & 2160 & 2150 & 2135 & 2123 & 2166 & 2160 & 2158 & 2184 & \\
\hline no. of Obs. & 57 & 65 & 170 & 7 & 34 & 1700 & 6969 & 5584 & 749 & 5 & 13 & \\
\hline Columbia River (CR) & 2179 & 2151 & 2111 & 2034 & 2049 & 2082 & 2076 & 2080 & 2113 & 2142 & 2187 & \\
\hline no. of Obs. & 120 & 19 & 98 & 23 & 135 & 3456 & 1545 & 3059 & 719 & 24 & 46 & \\
\hline Juan de Fuca (JF) & 2097 & 2111 & 2116 & 2081 & 2115 & 2125 & 2113 & 2125 & 2140 & 2126 & 2133 & 2137 \\
\hline no. of Obs. & 68 & 2099 & 172 & 48 & 267 & 627 & 2046 & 816 & 152 & 44 & 43 & 40 \\
\hline Strait of Georgia (SG) & & 2012 & & 1984 & 1980 & 1965 & 1842 & 2045 & 2071 & 2073 & & \\
\hline no. of Obs. & & 192 & & 5 & 58 & 32 & 5 & 35 & 6 & 1 & & \\
\hline Hood Canal (HC) & 1941 & 2007 & 1870 & 1972 & 2011 & 1935 & 1975 & 2033 & 2063 & 1999 & 1967 & \\
\hline no. of Obs. & 1 & 24 & 3 & 3 & 3 & 3 & 27 & 28 & 6 & 71 & 25 & \\
\hline Puget Sound (PS) & 1795 & 1986 & 1894 & 1919 & 2046 & 1956 & 1963 & 2020 & 2023 & 2035 & 1989 & \\
\hline no. of Obs. & 12 & 57 & 17 & 12 & 35 & 93 & 287 & 257 & 32 & 49 & 15 & \\
\hline
\end{tabular}

Table B4. Average monthly DIC seasonal cycles for the eight unique regions. The total number of observations (no. of Obs.) contributing to the monthly average estimate is included.

\begin{tabular}{lrrrrrrrrrrrr}
\hline DIC $\left(\mu \mathrm{mol} \mathrm{kg}^{-1}\right.$ ) & Jan & Feb & Mar & Apr & May & Jun & Jul & Aug & Sep & Oct & Nov & Dec \\
\hline North Pacific (NP) & 2019 & 2027 & 2029 & 1992 & 1974 & 1954 & 1941 & 1940 & 1950 & 1964 & 1990 & 2017 \\
no. of Obs. & 163 & 446 & 250 & 66 & 305 & 2791 & 4024 & 1814 & 504 & 88 & 109 & 29 \\
British Columbia (BC) & 1998 & 2015 & 1992 & 1944 & 1903 & 1928 & 1935 & 1959 & 1967 & 2012 & 2001 & 2000 \\
no. of Obs. & 162 & 627 & 205 & 160 & 462 & 1104 & 8067 & 1732 & 250 & 229 & 110 & 100 \\
Outer Coast (OC) & 2008 & 2023 & 2006 & 1941 & 1962 & 1918 & 1879 & 1928 & 1919 & 1957 & 1993 & \\
no. of Obs. & 57 & 65 & 170 & 7 & 34 & 1700 & 6969 & 5585 & 749 & 5 & 13 & \\
Columbia River (CR) & 2014 & 1988 & 1926.5 & 1852 & 1855 & 1874 & 1831 & 1841 & 1897 & 1938 & 1989 & \\
no. of Obs. & 120 & 19 & 98 & 23 & 135 & 3456 & 1545 & 3059 & 719 & 24 & 46 & \\
Juan de Fuca (JF) & 1993 & 2034 & 2020 & 1956 & 1970 & 2024 & 2016 & 2038 & 2056 & 2054 & 2031 & 2075 \\
no. of Obs. & 68 & 2103 & 172 & 48 & 301 & 633 & 2044 & 827 & 152 & 44 & 43 & 40 \\
Strait of Georgia (SG) & & 1966 & & 1857 & 1808 & 1833 & 1702 & 1905 & 1981 & 1958 & & \\
no. of Obs. & & 192 & & 5 & 58 & 32 & 5 & 35 & 6 & 1 & & \\
Hood Canal (HC) & 1921 & 1964 & 1628 & 1756 & 1822 & 1784 & 1783 & 1888 & 1944 & 1951 & 1972 & \\
no. of Obs. & 1 & 24 & 3 & 3 & 3 & 3 & 27 & 28 & 6 & 71 & 25 & \\
Puget Sound (PS) & 1778 & 1944 & 1844 & 1751 & 1915 & 1830 & 1820 & 1881 & 1919 & 1932 & 1959 & \\
no. of Obs. & 12 & 57 & 17 & 12 & 35 & 93 & 287 & 257 & 32 & 49 & 15 & \\
\hline
\end{tabular}


Table B5. Average monthly $f \mathrm{CO}_{2}$ seasonal cycles for the eight unique regions. The total number of observations (no. of Obs.) contributing to the monthly average estimate is included.

\begin{tabular}{|c|c|c|c|c|c|c|c|c|c|c|c|c|}
\hline$f \mathrm{CO}_{2}(\mu \mathrm{atm})$ & Jan & Feb & Mar & Apr & May & Jun & Jul & Aug & Sep & Oct & Nov & Dec \\
\hline North Pacific (NP) & 361 & 363 & 343 & 320 & 320 & 322 & 340 & 338 & 344 & 344 & 349 & 357 \\
\hline no. of Obs. & 163 & 446 & 250 & 66 & 364 & 2791 & 4026 & 1876 & 504 & 88 & 109 & 29 \\
\hline British Columbia (BC) & 402 & 413 & 380 & 300 & 261 & 290 & 335 & 349 & 368 & 445 & 404 & 432 \\
\hline no. of Obs. & 164 & 648 & 205 & 160 & 562 & 1083 & 8078 & 1922 & 248 & 229 & 110 & 100 \\
\hline Outer Coast (OC) & 358 & 385 & 356 & 264 & 337 & 288 & 282 & 275 & 285 & 359 & 351 & \\
\hline no. of Obs. & 57 & 65 & 170 & 7 & 34 & 1700 & 6969 & 6301 & 750 & 5 & 13 & \\
\hline Columbia River (CR) & 373 & 341 & 311 & 277 & 287 & 287 & 257 & 275 & 323 & 350 & 340 & \\
\hline no. of Obs. & 120 & 19 & 98 & 23 & 135 & 3456 & 1545 & 3614 & 719 & 24 & 46 & \\
\hline Juan de Fuca (JF) & 486 & 621 & 550 & 438 & 433 & 584 & 624 & 655 & 699 & 769 & 609 & 724 \\
\hline no. of Obs. & 69 & 2110 & 172 & 48 & 367 & 638 & 2094 & 832 & 157 & 44 & 43 & 40 \\
\hline Strait of Georgia (SG) & & 694 & & 386 & 304 & 400 & 300 & 466 & 621 & 500 & & \\
\hline no. of Obs. & & 197 & & 5 & 59 & 33 & 5 & 35 & 6 & 1 & & \\
\hline Hood Canal (HC) & 879 & 750 & 161 & 211 & 274 & 356 & 325 & 462 & 607 & 1032 & 1311 & \\
\hline no. of Obs. & 1 & 24 & 3 & 3 & 3 & 3 & 27 & 28 & 6 & 71 & 25 & \\
\hline Puget Sound (PS) & 794 & 742 & 654 & 283 & 286 & 416 & 422 & 487 & 614 & 607 & 948 & \\
\hline no. of Obs. & 12 & 57 & 17 & 12 & 35 & 93 & 298 & 257 & 32 & 49 & 15 & \\
\hline
\end{tabular}

Table B6. Average monthly $\mathrm{pH}$ seasonal cycles for the eight unique regions. The total number of observations (no. of Obs.) contributing to the monthly average estimate is included.

\begin{tabular}{lrrrrrrrrrrrr}
\hline $\mathrm{pH}$ & Jan & Feb & Mar & Apr & May & Jun & Jul & Aug & Sep & Oct & Nov & Dec \\
\hline North Pacific (NP) & 8.07 & 8.07 & 8.09 & 8.12 & 8.12 & 8.11 & 8.09 & 8.10 & 8.09 & 8.09 & 8.08 & 8.07 \\
no. of Obs. & 163 & 446 & 250 & 66 & 358 & 2791 & 4024 & 1770 & 504 & 88 & 109 & 29 \\
British Columbia (BC) & 8.02 & 8.02 & 8.05 & 8.14 & 8.18 & 8.16 & 8.11 & 8.09 & 8.07 & 8.00 & 8.03 & 8.00 \\
no. of Obs. & 160 & 647 & 205 & 160 & 455 & 1083 & 8067 & 1744 & 248 & 229 & 110 & 100 \\
Outer Coast (OC) & 8.07 & 8.05 & 8.07 & 8.19 & 8.10 & 8.15 & 8.16 & 8.14 & 8.16 & 8.07 & 8.08 & \\
no. of Obs. & 57 & 65 & 170 & 7 & 34 & 1700 & 6969 & 5585 & 749 & 5 & 13 & \\
Columbia River (CR) & 8.06 & 8.09 & 8.12 & 8.16 & 8.14 & 8.15 & 8.20 & 8.16 & 8.10 & 8.08 & 8.09 & \\
no. of Obs. & 120 & 19 & 98 & 23 & 135 & 3456 & 1545 & 3059 & 719 & 24 & 46 & \\
Juan de Fuca (JF) & 7.95 & 7.85 & 7.90 & 7.99 & 8.02 & 7.89 & 7.86 & 7.83 & 7.81 & 7.78 & 7.88 & 7.79 \\
no. of Obs. & 67 & 2110 & 172 & 48 & 301 & 635 & 2044 & 799 & 152 & 44 & 43 & 40 \\
Strait of Georgia (SG) & & 7.78 & & 8.03 & 8.13 & 8.02 & 8.08 & 7.98 & 7.85 & 7.93 & & \\
no. of Obs. & & 192 & & 5 & 58 & 32 & 5 & 35 & 6 & 1 & & \\
Hood Canal (HC) & 7.69 & 7.76 & 8.37 & 8.27 & 8.15 & 8.05 & 8.10 & 7.98 & 7.90 & 7.71 & 7.54 & \\
no. of Obs. & 1 & 24 & 3 & 3 & 3 & 3 & 27 & 28 & 6 & 71 & 25 & \\
Puget Sound (PS) & 7.71 & 7.76 & 7.81 & 8.16 & 7.99 & 8.00 & 8.02 & 7.97 & 7.88 & 7.87 & 7.67 & \\
no. of Obs. & 12 & 57 & 17 & 12 & 35 & 93 & 287 & 257 & 32 & 49 & 15 & \\
\hline
\end{tabular}


Table B7. Average monthly $\Omega_{\mathrm{Ar}}$ seasonal cycles for the eight unique regions. The total number of observations (no. of Obs.) contributing to the monthly average estimate is included.

\begin{tabular}{|c|c|c|c|c|c|c|c|c|c|c|c|c|}
\hline$\Omega_{\mathrm{Ar}}$ & Jan & Feb & Mar & Apr & May & Jun & Jul & Aug & Sep & Oct & Nov & Dec \\
\hline North Pacific (NP) & 1.9 & 1.9 & 2.0 & 2.1 & 2.2 & 2.3 & 2.4 & 2.5 & 2.5 & 2.4 & 2.1 & 1.9 \\
\hline no. of Obs. & 163 & 446 & 250 & 66 & 338 & 2791 & 4024 & 1814 & 504 & 88 & 109 & 29 \\
\hline British Columbia (BC) & 1.6 & 1.6 & 1.7 & 2.1 & 2.4 & 2.5 & 2.3 & 2.3 & 2.2 & 1.8 & 1.8 & 1.6 \\
\hline no. of Obs. & 161 & 647 & 205 & 160 & 455 & 1105 & 8067 & 1732 & 248 & 229 & 110 & 100 \\
\hline Outer Coast (OC) & 1.9 & 1.8 & 1.9 & 2.4 & 2.1 & 2.4 & 2.7 & 2.6 & 2.6 & 2.2 & 2.1 & \\
\hline no. of Obs. & 57 & 65 & 170 & 7 & 34 & 1700 & 6969 & 5585 & 749 & 5 & 13 & \\
\hline Columbia River (CR) & 1.9 & 1.8 & 2.0 & 2.0 & 2.1 & 2.3 & 2.7 & 2.6 & 2.4 & 2.3 & 2.2 & \\
\hline no. of Obs. & 120 & 19 & 98 & 23 & 135 & 3456 & 1545 & 3059 & 719 & 24 & 46 & \\
\hline Juan de Fuca (JF) & 1.3 & 1.1 & 1.2 & 1.5 & 1.7 & 1.3 & 1.3 & 1.2 & 1.2 & 1.1 & 1.3 & 1.0 \\
\hline no. of Obs. & 68 & 2110 & 172 & 48 & 300 & 633 & 2043 & 788 & 150 & 44 & 43 & 39 \\
\hline Strait of Georgia (SG) & & 0.8 & & 1.5 & 1.9 & 1.6 & 1.6 & 1.7 & 1.2 & 1.4 & & \\
\hline no. of Obs. & & 192 & & 5 & 58 & 32 & 5 & 35 & 6 & 1 & & \\
\hline Hood Canal (HC) & 0.6 & 0.8 & 2.6 & 2.4 & 2.1 & 1.7 & 2.2 & 1.7 & 1.5 & 1.0 & 0.5 & \\
\hline no. of Obs. & 1 & 24 & 3 & 3 & 3 & 3 & 27 & 28 & 6 & 71 & 25 & \\
\hline Puget Sound (PS) & 0.6 & 0.8 & 0.8 & 1.9 & 1.5 & 1.5 & 1.7 & 1.6 & 1.3 & 1.3 & 0.7 & \\
\hline no. of Obs. & 12 & 57 & 17 & 12 & 35 & 93 & 287 & 257 & 32 & 49 & 15 & \\
\hline
\end{tabular}

Table B8. Average monthly Revelle factor seasonal cycles for the eight unique regions. The total number of observations (no. of Obs.) contributing to the monthly average estimate is included.

\begin{tabular}{lrrrrrrrrrrrr}
\hline Revelle factor & Jan & Feb & Mar & Apr & May & Jun & Jul & Aug & Sep & Oct & Nov & Dec \\
\hline North Pacific (NP) & 13.0 & 13.1 & 12.5 & 12.1 & 11.8 & 11.5 & 11.3 & 11.0 & 11.1 & 11.4 & 12.1 & 12.9 \\
no. of Obs. & 163 & 446 & 250 & 66 & 356 & 2791 & 4024 & 1814 & 504 & 88 & 109 & 29 \\
British Columbia (BC) & 14.1 & 14.1 & 13.7 & 12.1 & 11.2 & 11.2 & 11.6 & 11.9 & 12.0 & 13.5 & 13.4 & 14.4 \\
no. of Obs. & 160 & 647 & 205 & 160 & 459 & 1082 & 8067 & 1727 & 248 & 229 & 110 & 100 \\
Outer Coast (OC) & 13.1 & 13.4 & 12.9 & 11.3 & 12.3 & 11.3 & 10.6 & 10.8 & 10.7 & 11.7 & 12.2 & \\
no. of Obs. & 57 & 65 & 170 & 7 & 34 & 1700 & 6969 & 5585 & 749 & 5 & 13 & \\
Columbia River (CR) & 13.1 & 13.2 & 12.2 & 12.2 & 11.8 & 11.5 & 10.5 & 10.7 & 11.2 & 11.6 & 11.9 & \\
no. of Obs. & 120 & 19 & 98 & 23 & 135 & 3456 & 1545 & 3059 & 719 & 24 & 46 & \\
Juan de Fuca (JF) & 15.7 & 17.2 & 16.2 & 14.7 & 14.0 & 15.9 & 16.1 & 16.5 & 16.6 & 17.1 & 15.8 & 17.8 \\
no. of Obs. & 67 & 2110 & 172 & 48 & 300 & 635 & 2043 & 795 & 152 & 44 & 43 & 39 \\
Strait of Georgia (SG) & & 18.6 & & 14.6 & 12.5 & 14.1 & 13.2 & 13.9 & 16.2 & 15.0 & & \\
no. of Obs. & & 192 & & 5 & 58 & 32 & 5 & 35 & 6 & 1 & & \\
Hood Canal (HC) & 19.9 & 18.7 & 10.3 & 11.2 & 11.8 & 13.0 & 11.7 & 13.7 & 14.9 & 16.3 & 18.5 & \\
no. of Obs. & 1 & 24 & 3 & 3 & 3 & 3 & 27 & 28 & 6 & 71 & 25 & \\
Puget Sound (PS) & 20.2 & 18.8 & 18.7 & 12.9 & 14.2 & 14.2 & 13.6 & 14.0 & 15.6 & 15.7 & 18.9 & \\
no. of Obs. & 12 & 57 & 17 & 12 & 35 & 93 & 287 & 257 & 32 & 49 & 15 & \\
\hline
\end{tabular}




\section{Appendix C}

Table C1. Average monthly SSS seasonal cycles for the nine Washington State moorings. The average monthly standard deviation (SD) and total number of observations (no. of Obs.) contributing to the monthly average estimate are included.

\begin{tabular}{|c|c|c|c|c|c|c|c|c|c|c|c|c|}
\hline SSS & Jan & Feb & Mar & Apr & May & Jun & Jul & Aug & Sep & Oct & Nov & Dec \\
\hline Chá bă (CB) & 30.3 & 30.7 & 30.6 & 30.5 & 30.8 & 31.2 & 31.5 & 31.9 & 31.9 & 31.8 & 31.8 & 31.4 \\
\hline SD & 1.2 & 1.2 & 1.6 & 1.1 & 0.4 & 1.2 & 0.8 & 0.3 & 0.5 & 0.5 & 0.5 & 0.7 \\
\hline no. of Obs. & 398 & 224 & 248 & 280 & 485 & 1080 & 1461 & 1648 & 1346 & 1029 & 646 & 496 \\
\hline Cape Elizabeth (CE) & 31.1 & 30.7 & 30.9 & 30.4 & 30.5 & 31.2 & 31.7 & 32.0 & 31.9 & 31.8 & 31.8 & 31.5 \\
\hline SD & 1.3 & 1.5 & 1.4 & 1.3 & 1.5 & 1.1 & 0.7 & 0.3 & 0.5 & 0.5 & 0.6 & 0.8 \\
\hline no. of Obs. & 1488 & 1352 & 1295 & 1199 & 1161 & 1246 & 1715 & 1812 & 1621 & 1756 & 1538 & 1484 \\
\hline Twanoh (TW) & 24.5 & 24.5 & 24.7 & 24.6 & 24.7 & 25.1 & 25.7 & 26.4 & 26.5 & 26.2 & 25.8 & 25.1 \\
\hline SD & 2.7 & 2.3 & 2.3 & 1.8 & 1.5 & 1.0 & 1.1 & 0.7 & 1.0 & 1.7 & 2.5 & 2.7 \\
\hline no. of Obs. & 684 & 913 & 1443 & 2678 & 3332 & 3234 & 3169 & 3664 & 3993 & 3220 & 1545 & 591 \\
\hline Dabob Bay (DB) & 29.2 & 28.3 & 27.6 & 26.8 & 26.6 & 26.6 & 26.2 & 27.3 & 28.3 & 28.9 & 28.0 & 28.6 \\
\hline SD & 0.1 & 0.6 & 0.8 & 0.5 & 0.5 & 0.8 & 1.0 & 0.9 & 0.3 & 0.5 & 1.0 & 0.9 \\
\hline no. of Obs. & 34 & 33 & 85 & 109 & 174 & 286 & 767 & 1167 & 1138 & 667 & 163 & 39 \\
\hline Carr Inlet (CI) & 28.8 & 28.5 & 28.2 & 28.1 & 28.2 & 28.4 & 28.8 & 29.1 & 29.4 & 29.7 & 29.7 & 29.2 \\
\hline SD & 0.2 & 0.2 & 0.2 & 0.2 & 0.2 & 0.1 & 0.1 & 0.1 & 0.1 & 0.2 & 0.1 & 0.2 \\
\hline no. of & 349 & 347 & 1008 & 937 & 820 & 1161 & 1629 & 1641 & 1611 & 1566 & 716 & 584 \\
\hline Bellingham Bay (BB) & 28.5 & 19.3 & 24.3 & 23.0 & 24.4 & 25.4 & 24.4 & 25.9 & 27.3 & 24.4 & 22.0 & 26.9 \\
\hline SD & 2.9 & 8.5 & 5.1 & 4.9 & 3.3 & 3.3 & 2.9 & 2.2 & 2.6 & 6.7 & 7.7 & 3.9 \\
\hline no. of Obs. & 844 & 2102 & 4308 & 3611 & 4365 & 4227 & 4317 & 3958 & 4223 & 4383 & 4218 & 4339 \\
\hline Hoodsport (HS) & 25.8 & 25.9 & 26.2 & 26.4 & 25.9 & 26.4 & 26.4 & 27.0 & 27.5 & 27.7 & 27.4 & 26.3 \\
\hline SD & 2.3 & 2.2 & 1.9 & 1.4 & 1.4 & 1.2 & 1.2 & 0.9 & 1.0 & 1.4 & 1.9 & 2.1 \\
\hline no. $o$ & 346 & 309 & 593 & 1325 & 1991 & 1477 & 2669 & 3241 & 2332 & 1682 & 850 & 371 \\
\hline Point Wells (PW) & 28.3 & 27.8 & 28.2 & 28.1 & 28.4 & 28.2 & 28.8 & 29.4 & 29.8 & 30.0 & 29.3 & 28.6 \\
\hline SD & 1.2 & 0.9 & 0.5 & 0.5 & 0.4 & 0.5 & 0.4 & 0.2 & 0.2 & 0.2 & 0.8 & 0.6 \\
\hline no. of Obs. & 128 & 84 & 208 & 275 & 474 & 379 & 631 & 494 & 398 & 751 & 364 & 129 \\
\hline North Buoy (NB) & 28.9 & 28.9 & 29.1 & 29.2 & 29.1 & 29.2 & 29.6 & 29.9 & 30.0 & 30.3 & 29.9 & 29.4 \\
\hline SD & 0.6 & 0.5 & 0.4 & 0.2 & 0.3 & 0.3 & 0.3 & 0.2 & 0.2 & 0.3 & 0.5 & 0.5 \\
\hline no. of Obs. & 329 & 474 & 349 & 578 & 884 & 972 & 1476 & 1734 & 858 & 1320 & 693 & 532 \\
\hline
\end{tabular}


Table C2. Average monthly SST seasonal cycles for the nine Washington State moorings. The average monthly standard deviation (SD) and total number of observations (no. of Obs.) contributing to the monthly average estimate are included.

\begin{tabular}{|c|c|c|c|c|c|c|c|c|c|c|c|c|}
\hline $\operatorname{SST}\left({ }^{\circ} \mathrm{C}\right)$ & Jan & $\mathrm{Feb}$ & Mar & Apr & May & Jun & Jul & Aug & Sep & Oct & Nov & Dec \\
\hline Chá bă (CB) & 8.6 & 7.8 & 8.9 & 10.0 & 11.2 & 13.1 & 13.7 & 14.0 & 13.9 & 13.5 & 11.7 & 9.5 \\
\hline SD & 0.6 & 0.4 & 0.6 & 0.5 & 0.6 & 0.8 & 1.0 & 0.9 & 0.9 & 0.5 & 0.7 & 0.6 \\
\hline no. of Obs. & 398 & 224 & 248 & 280 & 485 & 1080 & 1461 & 1673 & 1553 & 1173 & 646 & 496 \\
\hline Cape Elizabeth (CE) & 9.2 & 9.0 & 9.2 & 9.7 & 11.2 & 12.8 & 13.7 & 13.8 & 14.1 & 12.8 & 11.5 & 10.1 \\
\hline $\mathrm{SD}$ & 0.6 & 0.4 & 0.4 & 0.5 & 1.0 & 1.0 & 1.2 & 0.9 & 0.9 & 0.8 & 0.7 & 0.6 \\
\hline no. of Obs. & 1488 & 1352 & 1295 & 1199 & 1161 & 1246 & 1715 & 1812 & 1621 & 1829 & 1778 & 1513 \\
\hline Twanoh (TW) & 8.6 & 8.8 & 9.6 & 11.2 & 13.8 & 16.1 & 18.4 & 18.4 & 16.0 & 12.5 & 10.2 & 8.9 \\
\hline SD & 0.8 & 0.7 & 0.6 & 1.0 & 1.4 & 1.6 & 1.8 & 1.6 & 1.8 & 1.3 & 0.8 & 0.9 \\
\hline no. of Obs. & 684 & 913 & 1443 & 2678 & 3332 & 3234 & 3169 & 3664 & 3993 & 3220 & 1545 & 591 \\
\hline Dabob Bay (DB) & 7.8 & 7.5 & 8.5 & 9.9 & 13.7 & 15.9 & 18.4 & 18.4 & 16.0 & 12.5 & 10.3 & 8.4 \\
\hline SD & 0.2 & 0.3 & 0.4 & 0.5 & 0.9 & 1.5 & 1.8 & 1.7 & 1.5 & 1.1 & 0.6 & 0.7 \\
\hline no. of Obs. & 34 & 33 & 85 & 109 & 174 & 286 & 767 & 1167 & 1138 & 667 & 163 & 39 \\
\hline Carr Inlet (CI) & 8.7 & 8.5 & 8.7 & 10.0 & 11.8 & 13.3 & 14.7 & 15.4 & 14.7 & 13.2 & 11.8 & 9.8 \\
\hline SD & 0.2 & 0.2 & 0.4 & 0.7 & 1.0 & 1.4 & 1.3 & 1.3 & 0.9 & 0.5 & 0.5 & 0.4 \\
\hline no. of Obs. & 349 & 347 & 1,008 & 937 & 820 & 1161 & 1629 & 1641 & 1611 & 1566 & 716 & 584 \\
\hline Bellingham Bay (BB) & 6.7 & 8.2 & 9.1 & 12.2 & 14.3 & 14.9 & 17.4 & 17.6 & 14.7 & 11.4 & 9.9 & 7.4 \\
\hline SD & 0.7 & 0.7 & 0.6 & 1.2 & 1.2 & 1.2 & 1.6 & 1.3 & 1.3 & 0.9 & 1.0 & 1.2 \\
\hline no. of Obs. & 844 & 2102 & 4308 & 3611 & 4365 & 4227 & 4317 & 3958 & 4223 & 4383 & 4218 & 4339 \\
\hline Hoodsport (HS) & 8.7 & 8.6 & 9.3 & 10.5 & 12.9 & 14.4 & 17.0 & 16.7 & 14.4 & 11.7 & 10.4 & 9.3 \\
\hline SD & 0.9 & 0.7 & 0.4 & 0.9 & 1.5 & 1.5 & 2.0 & 1.7 & 1.7 & 1.3 & 0.7 & 0.8 \\
\hline no. of Obs. & 346 & 309 & 593 & 1325 & 1991 & 1477 & 2669 & 3241 & 2332 & 1682 & 850 & 371 \\
\hline Point Wells (PW) & 8.1 & 8.2 & 8.5 & 9.6 & 10.9 & 12.1 & 13.2 & 13.6 & 13.1 & 12.6 & 11.3 & 9.3 \\
\hline SD & 0.3 & 0.3 & 0.2 & 0.3 & 0.6 & 0.7 & 0.6 & 0.5 & 0.3 & 0.3 & 0.6 & 0.4 \\
\hline no. of Obs. & 128 & 84 & 208 & 275 & 474 & 379 & 631 & 494 & 398 & 751 & 364 & 129 \\
\hline North Buoy (NB) & 8.4 & 8.2 & 8.5 & 9.1 & 10.6 & 11.7 & 13.0 & 13.1 & 12.7 & 11.2 & 10.3 & 8.8 \\
\hline SD & 0.2 & 0.1 & 0.3 & 0.4 & 0.5 & 0.7 & 0.7 & 0.6 & 0.4 & 0.3 & 0.4 & 0.4 \\
\hline no. of Obs. & 329 & 474 & 349 & 578 & 884 & 972 & 1476 & 1734 & 858 & 1320 & 693 & 532 \\
\hline
\end{tabular}


Table C3. Average monthly TA seasonal cycles for the eight Washington State moorings with appropriate SSS observations (vast majority of SSS $>20$ ) to estimate TA. The average monthly standard deviation (SD) and total number of observations (no. of Obs.) contributing to the monthly average estimate are included.

\begin{tabular}{lrrrrrrrrrrrr}
\hline TA $(\mu$ mol kg & -1 \\
Chá bă (CB) & Jan & Feb & Mar & Apr & May & Jun & Jul & Aug & Sep & Oct & Nov & Dec \\
SD & 2090 & 2108 & 2105 & 2102 & 2114 & 2132 & 2148 & 2165 & 2167 & 2161 & 2162 & 2142 \\
no. of Obs. & 59 & 58 & 77 & 54 & 20 & 55 & 40 & 12 & 25 & 22 & 22 & 34 \\
Cape Elizabeth (CE) & 2130 & 224 & 248 & 280 & 485 & 1080 & 1461 & 1648 & 1346 & 1029 & 646 & 496 \\
SD & 210 & 2118 & 2094 & 2101 & 2135 & 2156 & 2173 & 2168 & 2162 & 2164 & 2149 \\
no. of Obs. & 1488 & 1352 & 67 & 60 & 73 & 53 & 32 & 14 & 24 & 24 & 28 & 38 \\
Twanoh (TW) & 1815 & 1815 & 1823 & 1199 & 1161 & 1246 & 1715 & 1812 & 1621 & 1756 & 1538 & 1484 \\
SD & 127 & 109 & 108 & 855 & 71 & 1844 & 1870 & 1903 & 1909 & 1896 & 1876 & 1842 \\
no. of Obs. & 684 & 913 & 1443 & 2678 & 3332 & 3234 & 3169 & 3664 & 3993 & 3220 & 1545 & 591 \\
Dabob Bay (DB) & 2037 & 1996 & 1964 & 1922 & 1915 & 1916 & 1895 & 1945 & 1997 & 2022 & 1980 & 2012 \\
SD & 6 & 29 & 39 & 24 & 24 & 39 & 49 & 41 & 16 & 22 & 47 & 45 \\
no. of Obs. & 34 & 33 & 85 & 109 & 174 & 286 & 767 & 1167 & 1138 & 667 & 163 & 39 \\
Carr Inlet (CI) & 2019 & 2007 & 1992 & 1988 & 1991 & 2002 & 2020 & 2033 & 2047 & 2060 & 2064 & 2036 \\
SD & 11 & 8 & 11 & 7 & 7 & 7 & 7 & 5 & 7 & 8 & 7 & 11 \\
no. of Obs. & 349 & 347 & 1008 & 937 & 820 & 1161 & 1629 & 1641 & 1611 & 1566 & 716 & 584 \\
Hoodsport (HS) & 1890 & 1891 & 1897 & 1904 & 1881 & 1904 & 1904 & 1932 & 1957 & 1968 & 1959 & 1907 \\
SD & 93 & 86 & 82 & 67 & 69 & 55 & 55 & 44 & 48 & 65 & 80 & 91 \\
no. of Obs. & 337 & 302 & 590 & 1323 & 1991 & 1477 & 2669 & 3241 & 2332 & 1681 & 843 & 361 \\
Point Wells (PW) & 1995 & 1972 & 1992 & 1986 & 1998 & 1989 & 2020 & 2050 & 2066 & 2078 & 2042 & 2010 \\
SD & 58 & 41 & 25 & 22 & 20 & 25 & 19 & 12 & 7 & 11 & 40 & 28 \\
no. of Obs. & 128 & 84 & 208 & 275 & 474 & 379 & 631 & 494 & 398 & 751 & 364 & 129 \\
North Buoy (NB) & 2026 & 2023 & 2033 & 2038 & 2036 & 2038 & 2055 & 2073 & 2076 & 2090 & 2072 & 2047 \\
SD & 29 & 22 & 19 & 12 & 15 & 16 & 15 & 12 & 12 & 15 & 22 & 25 \\
no. of Obs. & 329 & 474 & 349 & 578 & 884 & 972 & 1476 & 1734 & 858 & 1320 & 693 & 532 \\
\hline
\end{tabular}


Table C4. Average monthly DIC seasonal cycles for the five Washington State moorings with sufficient observations to estimate DIC. The average monthly standard deviation (SD) and total number of observations (no. of Obs.) contributing to the monthly average estimate are included.

\begin{tabular}{|c|c|c|c|c|c|c|c|c|c|c|c|c|}
\hline $\mathrm{DIC}\left(\mu \mathrm{mol} \mathrm{kg}{ }^{-1}\right)$ & Jan & Feb & Mar & Apr & May & Jun & Jul & Aug & Sep & Oct & Nov & Dec \\
\hline Chá bă (CB) & 1936 & 1964 & 1973 & 1882 & 1846 & 1850 & 1891 & 1922 & 1950 & 1960 & 1981 & 1975 \\
\hline SD & 47 & 54 & 72 & 56 & 34 & 66 & 57 & 41 & 36 & 25 & 29 & 33 \\
\hline no. of Obs. & 398 & 221 & 245 & 279 & 484 & 1080 & 1461 & 1648 & 1346 & 1028 & 645 & 495 \\
\hline Cape Elizabeth (CE) & 1975 & 1949 & 1944 & 1898 & 1891 & 1893 & 1915 & 1925 & 1944 & 1958 & 1986 & 1987 \\
\hline $\mathrm{SD}$ & 54 & 70 & 64 & 57 & 71 & 54 & 47 & 41 & 49 & 41 & 34 & 34 \\
\hline no. of Obs. & 1485 & 1347 & 1295 & 1199 & 1158 & 1244 & 1715 & 1812 & 1619 & 1753 & 1506 & 1484 \\
\hline Twanoh (TW) & 1783 & 1722 & 1630 & 1644 & 1688 & 1705 & 1709 & 1726 & 1784 & 1747 & 1779 & 1815 \\
\hline SD & 67 & 97 & 88 & 80 & 73 & 56 & 50 & 33 & 54 & 81 & 104 & 75 \\
\hline no. of Obs. & 371 & 392 & 506 & 725 & 875 & 877 & 743 & 961 & 1650 & 1145 & 613 & 363 \\
\hline Dabob Bay (DB) & 1991 & 1929 & 1828 & 1728 & & 1716 & 1677 & 1720 & 1788 & 1867 & 1931 & 1904 \\
\hline SD & 7 & 31 & 82 & 51 & & 36 & 51 & 38 & 31 & 52 & 22 & 41 \\
\hline no. of Obs. & 28 & 132 & 265 & 36 & & 150 & 317 & 496 & 378 & 118 & 139 & 17 \\
\hline Carr Inlet (CI) & 1946 & 1923 & 1897 & 1769 & 1824 & 1831 & 1773 & 1886 & 1891 & 1928 & 2,021 & 1944 \\
\hline $\mathrm{SD}$ & 20 & 18 & 31 & 68 & 48 & 36 & 97 & 68 & 72 & 89 & 16 & 18 \\
\hline no. of Obs. & 51 & 42 & 112 & 130 & 140 & 56 & 228 & 372 & 360 & 268 & 74 & 15 \\
\hline
\end{tabular}

Table C5. Average monthly $f \mathrm{CO}_{2}$ seasonal cycles for the five Washington State moorings with $\mathrm{CO}_{2}$ sensors or sufficient observations to estimate $f \mathrm{CO}_{2}$. The average monthly standard deviation (SD) and total number of observations (no. of Obs.) contributing to the monthly average estimate are included.

\begin{tabular}{|c|c|c|c|c|c|c|c|c|c|c|c|c|}
\hline$f \mathrm{CO}_{2}(\mu \mathrm{atm})$ & Jan & Feb & Mar & Apr & May & Jun & Jul & Aug & Sep & Oct & Nov & Dec \\
\hline Chá bă (CB) & 341 & 358 & 415 & 245 & 204 & 212 & 258 & 283 & 325 & 342 & 358 & 349 \\
\hline SD & 24 & 30 & 74 & 41 & 33 & 48 & 68 & 58 & 45 & 25 & 40 & 26 \\
\hline no. of Obs. & 398 & 221 & 245 & 279 & 484 & 1080 & 1461 & 1648 & 1346 & 1028 & 645 & 495 \\
\hline Cape Elizabeth (CE) & 368 & 343 & 322 & 277 & 279 & 260 & 281 & 276 & 316 & 330 & 364 & 371 \\
\hline SD & 29 & 38 & 34 & 36 & 41 & 51 & 57 & 52 & 51 & 47 & 34 & 21 \\
\hline no. of Obs. & 1485 & 1347 & 1295 & 1199 & 1158 & 1244 & 1715 & 1812 & 1619 & 1753 & 1506 & 1484 \\
\hline Twanoh (TW) & 619 & 427 & 231 & 233 & 346 & 383 & 342 & 344 & 392 & 379 & 487 & 655 \\
\hline SD & 144 & 201 & 103 & 88 & 58 & 75 & 34 & 30 & 64 & 145 & 263 & 217 \\
\hline no. of Obs. & 371 & 392 & 506 & 725 & 875 & 877 & 743 & 961 & 1650 & 1145 & 613 & 363 \\
\hline Dabob Bay (DB) & 748 & 575 & 420 & 205 & & 288 & 297 & 291 & 311 & 428 & 583 & 636 \\
\hline SD & 49 & 67 & 132 & 56 & & 19 & 25 & 18 & 56 & 211 & 73 & 15 \\
\hline no. of Obs. & 28 & 132 & 265 & 36 & & 150 & 317 & 496 & 378 & 118 & 139 & 17 \\
\hline Carr Inlet (CI) & 731 & 679 & 602 & 261 & 351 & 377 & 264 & 450 & 420 & 502 & 843 & 659 \\
\hline SD & 64 & 67 & 137 & 133 & 84 & 84 & 167 & 177 & 184 & 241 & 69 & 57 \\
\hline no. of Obs. & 51 & 42 & 112 & 130 & 140 & 56 & 228 & 372 & 360 & 268 & 74 & 15 \\
\hline
\end{tabular}


Table C6. Average monthly $\mathrm{pH}$ seasonal cycles for the six Washington State moorings with $\mathrm{pH}$ sensors or sufficient observations to estimate $\mathrm{pH}$. The average monthly standard deviation (SD) and total number of observations (no. of Obs.) contributing to the monthly average estimate are included.

\begin{tabular}{|c|c|c|c|c|c|c|c|c|c|c|c|c|}
\hline $\mathrm{pH}$ & Jan & Feb & Mar & Apr & May & Jun & Jul & Aug & Sep & Oct & Nov & Dec \\
\hline Chá bă (CB) & 8.07 & 8.08 & 8.02 & 8.22 & 8.27 & 8.26 & 8.21 & 8.17 & 8.11 & 8.09 & 8.06 & 8.07 \\
\hline SD & 0.03 & 0.03 & 0.06 & 0.06 & 0.06 & 0.09 & 0.09 & 0.08 & 0.07 & 0.03 & 0.05 & 0.03 \\
\hline no. of Obs. & 398 & 222 & 248 & 279 & 495 & 1117 & 1461 & 1648 & 1547 & 1172 & 646 & 496 \\
\hline Cape Elizabeth (CE) & 8.06 & 8.08 & 8.11 & 8.17 & 8.17 & 8.20 & 8.17 & 8.18 & 8.13 & 8.11 & 8.07 & 8.06 \\
\hline SD & 0.03 & 0.04 & 0.04 & 0.05 & 0.05 & 0.07 & 0.07 & 0.07 & 0.06 & 0.06 & 0.04 & 0.02 \\
\hline no. of Obs. & 1485 & 1347 & 1295 & 1199 & 1158 & 1244 & 1715 & 1812 & 1619 & 1753 & 1506 & 1484 \\
\hline Twanoh (TW) & 7.84 & 8.03 & 8.22 & 8.23 & 8.06 & 8.02 & 8.07 & 8.06 & 8.02 & 8.04 & 7.98 & 7.86 \\
\hline SD & 0.14 & 0.22 & 0.16 & 0.13 & 0.06 & 0.06 & 0.04 & 0.03 & 0.06 & 0.13 & 0.22 & 0.11 \\
\hline no. of Obs. & 371 & 392 & 506 & 725 & 875 & 877 & 743 & 961 & 1650 & 1145 & 613 & 363 \\
\hline Dabob Bay (DB) & 7.76 & 7.86 & 8.01 & 8.26 & & 8.13 & 8.11 & 8.12 & 8.11 & 8.02 & 7.87 & 7.81 \\
\hline SD & 0.03 & 0.04 & 0.14 & 0.08 & & 0.02 & 0.03 & 0.02 & 0.05 & 0.13 & 0.06 & 0.02 \\
\hline no. of Obs. & 28 & 132 & 265 & 36 & & 150 & 317 & 496 & 378 & 118 & 139 & 17 \\
\hline Carr Inlet (CI) & 7.77 & 7.80 & 7.86 & 8.21 & 8.09 & 8.04 & 8.22 & 8.00 & 8.03 & 7.98 & 7.73 & 7.81 \\
\hline SD & 0.03 & 0.04 & 0.09 & 0.16 & 0.10 & 0.09 & 0.20 & 0.15 & 0.16 & 0.21 & 0.03 & 0.03 \\
\hline no. of Obs. & 51 & 42 & 112 & 130 & 140 & 56 & 228 & 372 & 360 & 268 & 74 & 15 \\
\hline Bellingham Bay (BB) & 8.07 & 7.81 & 7.95 & 8.12 & 8.25 & 8.12 & 7.99 & 7.99 & 8.16 & 7.99 & 7.94 & 8.06 \\
\hline SD & 0.03 & 0.08 & 0.09 & 0.20 & 0.10 & 0.12 & 0.19 & 0.17 & 0.07 & 0.11 & 0.09 & 0.05 \\
\hline no. of Obs. & 844 & 2114 & 4377 & 4168 & 4367 & 4227 & 4318 & 3963 & 4226 & 4385 & 4229 & 4365 \\
\hline
\end{tabular}

Table C7. Average monthly $\Omega_{\text {Ar }}$ seasonal cycles for the five Washington State moorings with sufficient observations to estimate $\Omega_{\text {Ar }}$. The average monthly standard deviation (SD) and total number of observations (no. of Obs.) contributing to the monthly average estimate are included.

\begin{tabular}{|c|c|c|c|c|c|c|c|c|c|c|c|c|}
\hline$\Omega_{\mathrm{Ar}}$ & Jan & Feb & Mar & Apr & May & Jun & Jul & Aug & Sep & Oct & Nov & Dec \\
\hline Chá bă (CB) & 1.7 & 1.6 & 1.5 & 2.4 & 2.9 & 3.0 & 2.8 & 2.7 & 2.4 & 2.2 & 2.0 & 1.9 \\
\hline SD & 0.2 & 0.1 & 0.2 & 0.3 & 0.3 & 0.5 & 0.5 & 0.4 & 0.3 & 0.1 & 0.2 & 0.1 \\
\hline no. of Obs. & 398 & 221 & 245 & 279 & 484 & 1080 & 1461 & 1648 & 1346 & 1028 & 645 & 495 \\
\hline Cape Elizabeth (CE) & 1.8 & 1.8 & 1.9 & 2.1 & 2.3 & 2.6 & 2.6 & 2.7 & 2.5 & 2.3 & 2.0 & 1.8 \\
\hline SD & 0.2 & 0.2 & 0.2 & 0.2 & 0.3 & 0.4 & 0.4 & 0.4 & 0.3 & 0.3 & 0.2 & 0.1 \\
\hline no. of Obs. & 1485 & 1347 & 1295 & 1199 & 1158 & 1244 & 1715 & 1812 & 1619 & 1753 & 1506 & 1484 \\
\hline Twanoh (TW) & 0.9 & 1.4 & 1.9 & 2.1 & 1.6 & 1.6 & 2.0 & 2.0 & 1.7 & 1.5 & 1.3 & 1.0 \\
\hline SD & 0.5 & 0.7 & 0.6 & 0.5 & 0.2 & 0.2 & 0.1 & 0.1 & 0.2 & 0.5 & 0.6 & 0.3 \\
\hline no. of Obs. & 371 & 392 & 506 & 725 & 875 & 877 & 743 & 961 & 1650 & 1145 & 613 & 363 \\
\hline Dabob Bay (DB) & 0.8 & 1.0 & 1.3 & 2.1 & & 2.0 & 2.1 & 2.2 & 2.2 & 1.7 & 1.1 & 0.8 \\
\hline $\mathrm{SD}$ & 0.0 & 0.1 & 0.5 & 0.2 & & 0.1 & 0.1 & 0.1 & 0.2 & 0.4 & 0.1 & 0.1 \\
\hline no. of Obs. & 28 & 132 & 265 & 36 & & 150 & 317 & 496 & 378 & 118 & 139 & 17 \\
\hline Carr Inlet (CI) & 0.9 & 0.9 & 1.0 & 2.3 & 1.9 & 1.8 & 3.0 & 2.0 & 2.1 & 1.9 & 1.0 & 1.0 \\
\hline SD & 0.1 & 0.1 & 0.2 & 0.6 & 0.4 & 0.3 & 1.0 & 0.7 & 0.7 & 0.8 & 0.1 & 0.0 \\
\hline no. of Obs. & 51 & 42 & 112 & 130 & 140 & 56 & 228 & 372 & 360 & 268 & 74 & 15 \\
\hline
\end{tabular}


Table C8. Average monthly Revelle factor seasonal cycles for the five Washington State moorings with sufficient observations to estimate the Revelle factor. The average monthly standard deviation (SD) and total number of observations (no. of Obs.) contributing to the monthly average estimate are included.

\begin{tabular}{|c|c|c|c|c|c|c|c|c|c|c|c|c|}
\hline Revelle factor & Jan & $\mathrm{Feb}$ & Mar & Apr & May & Jun & Jul & Aug & Sep & Oct & Nov & Dec \\
\hline Chá bă (CB) & 13.4 & 13.9 & 14.4 & 11.2 & 10.1 & 9.9 & 10.5 & 10.7 & 11.4 & 11.8 & 12.5 & 13.0 \\
\hline SD & 0.6 & 0.4 & 1.1 & 0.8 & 0.6 & 0.9 & 1.1 & 1.0 & 0.8 & 0.4 & 0.6 & 0.4 \\
\hline no. of Obs. & 398 & 221 & 245 & 279 & 484 & 1080 & 1461 & 1648 & 1346 & 1028 & 645 & 495 \\
\hline Cape Elizabeth (CE) & 13.5 & 13.2 & 12.7 & 11.9 & 11.5 & 10.8 & 10.8 & 10.7 & 11.2 & 11.7 & 12.6 & 13.2 \\
\hline SD & 0.6 & 0.6 & 0.5 & 0.7 & 0.7 & 1.0 & 0.9 & 0.9 & 0.8 & 0.8 & 0.6 & 0.4 \\
\hline no. of Obs. & 1485 & 1347 & 1295 & 1199 & 1158 & 1244 & 1715 & 1812 & 1619 & 1753 & 1506 & 1484 \\
\hline Twanoh (TW) & 18.1 & 15.5 & 12.5 & 11.9 & 13.6 & 13.5 & 12.1 & 12.1 & 13.4 & 14.1 & 15.4 & 17.1 \\
\hline SD & 1.8 & 3.0 & 2.3 & 1.8 & 0.9 & 1.0 & 0.5 & 0.4 & 1.0 & 2.0 & 2.9 & 1.2 \\
\hline no. of Obs. & 371 & 392 & 506 & 725 & 875 & 877 & 743 & 961 & 1650 & 1145 & 613 & 363 \\
\hline Dabob Bay (DB) & 18.7 & 17.6 & 15.5 & 11.5 & & 11.9 & 11.6 & 11.2 & 11.5 & 13.5 & 16.7 & 18.4 \\
\hline SD & 0.2 & 0.5 & 2.1 & 1.0 & & 0.3 & 0.4 & 0.3 & 0.8 & 1.7 & 0.9 & 0.6 \\
\hline no. of Obs. & 28 & 132 & 265 & 36 & & 150 & 317 & 496 & 378 & 118 & 139 & 17 \\
\hline Carr Inlet (CI) & 18.3 & 18.0 & 17.1 & 11.6 & 13.1 & 13.1 & 10.3 & 12.8 & 12.6 & 13.6 & 17.6 & 17.7 \\
\hline SD & 0.3 & 0.5 & 1.3 & 2.3 & 1.6 & 1.5 & 2.4 & 2.2 & 2.4 & 2.9 & 0.3 & 0.3 \\
\hline no. of Obs. & 51 & 42 & 112 & 130 & 140 & 56 & 228 & 372 & 360 & 268 & 74 & 15 \\
\hline
\end{tabular}




\section{Appendix D}

(a) SSS

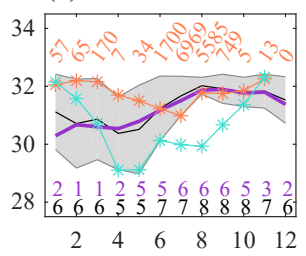

(e) $\mathbf{T A}$

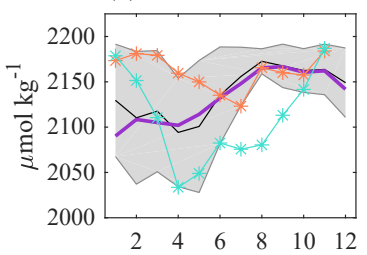

(b)
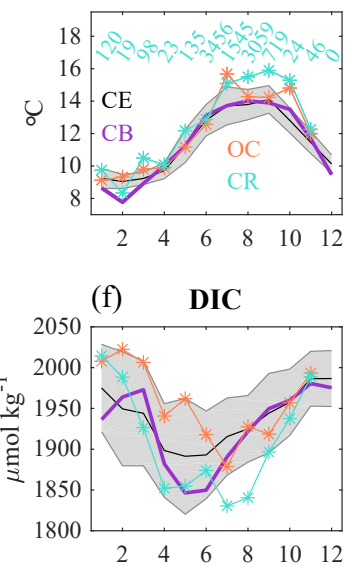
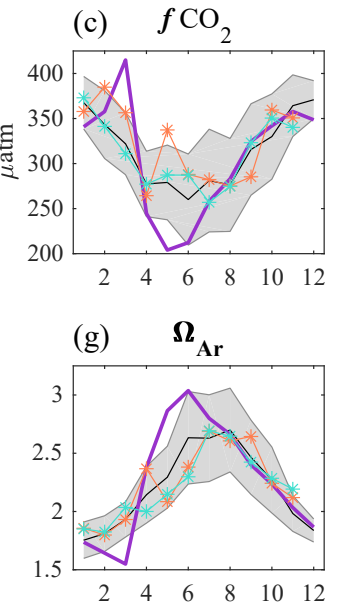

(d) $\quad \mathbf{p H}$
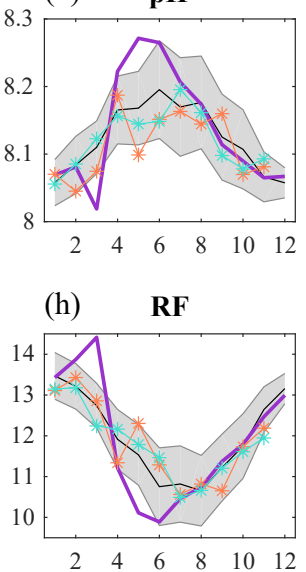

Figure D1. Seasonal cycles of (a) SSS, (b) SST, (c) $f \mathrm{CO}_{2}$, (d) $\mathrm{pH}$, (e) TA, (f) DIC, (g) $\Omega_{\mathrm{Ar}}$, and (h) RF at the Cape Elizabeth (CE) and Chá bă (CB) moorings and for the Outer Coast (OC) and Columbia River (CR) regions. Gray shading shows $\pm 1 \sigma$ for CE. Text near the bottom of (a) indicates the number of years of moored SSS, SST, and $f \mathrm{CO}_{2}$ observations contributing to the monthly seasonal cycle estimates. Slanted text in (a) and (b) indicates the total number of discrete observations contributing to the monthly seasonal cycle estimates.

(a) SSS

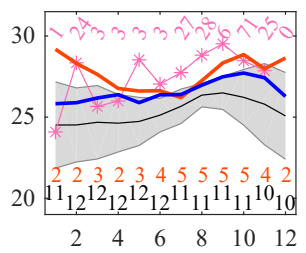

(e) $\mathbf{T A}$

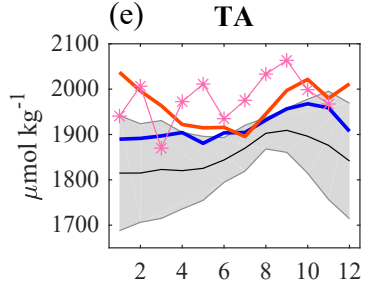

(b)

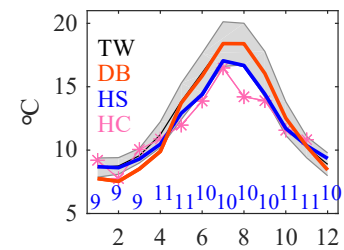

(f) DIC

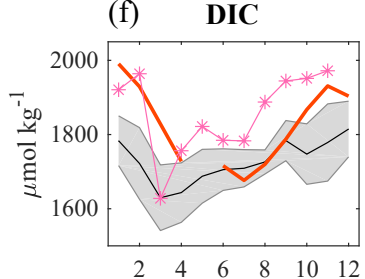

(c) $f \mathrm{CO}_{2}$
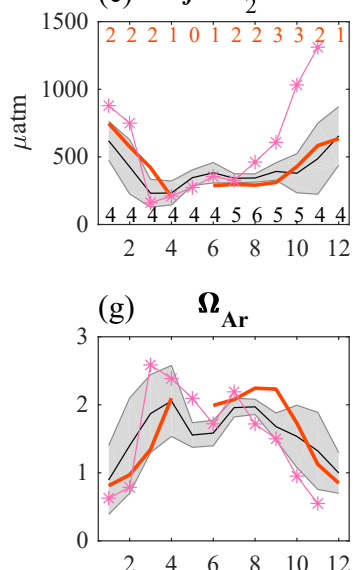

(d) $\quad \mathbf{p H}$

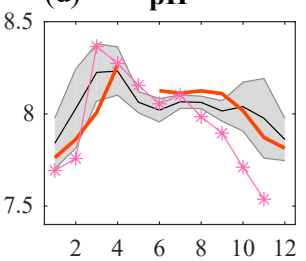

(h) $\quad$ RF

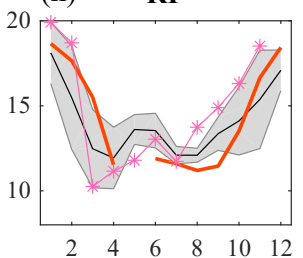

Figure D2. Seasonal cycles of (a) SSS, (b) SST, (c) $f \mathrm{CO}_{2}$, (d) $\mathrm{pH}_{\mathrm{T}}$, (e) TA, (f) DIC, (g) $\Omega_{\mathrm{Ar}}$, and (h) RF at the Twanoh (TW), Dabob Bay (DB), and Hoodsport (HP) moorings and for the Hood Canal (HC) region. Gray shading shows $\pm 1 \sigma$ for TW. Text near the bottom of (a) and (b) indicates the number of years of moored SSS and SST observations contributing to the monthly seasonal cycle estimates. Text in (c) indicates the same information but for the moored $f \mathrm{CO}_{2}$ observations. Text is staggered in (a) and (b) for viewing. Slanted text in (a) indicates the total number of discrete observations contributing to the monthly seasonal cycle estimates. 

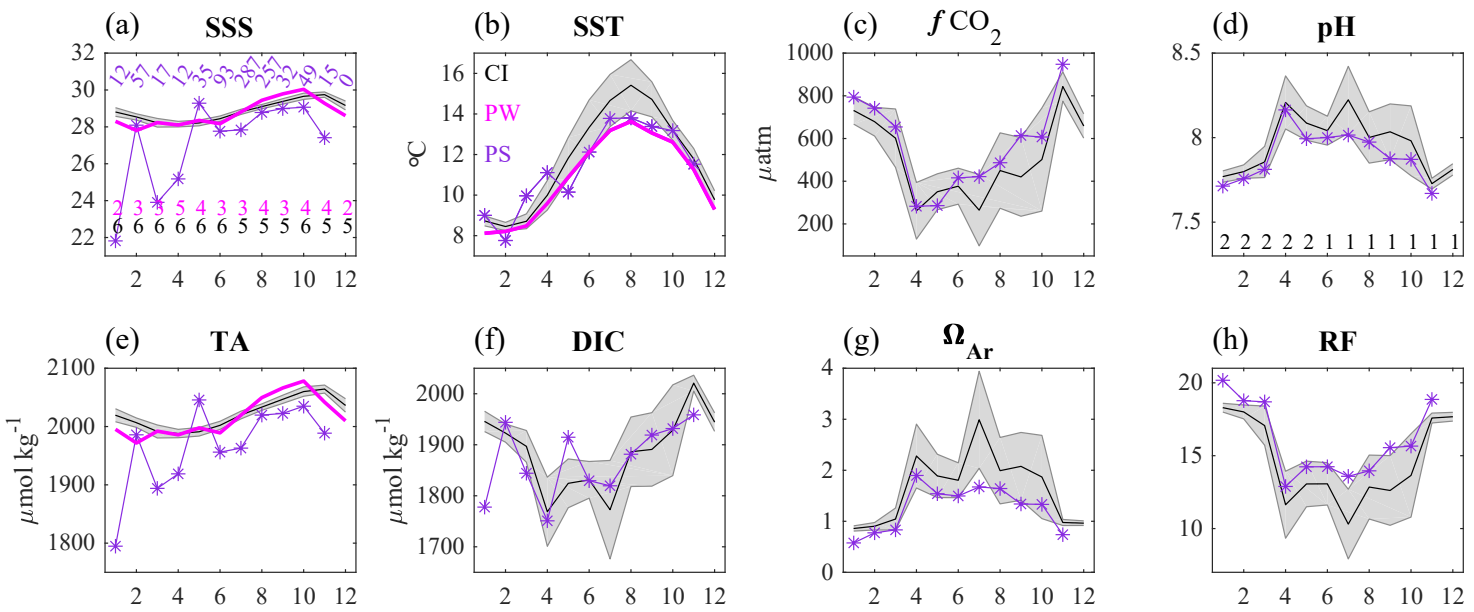

Figure D3. Seasonal cycles of (a) SSS, (b) SST, (c) $f \mathrm{CO}_{2}$, (d) $\mathrm{pH}_{\mathrm{T}}$, (e) TA, (f) DIC, (g) $\Omega_{\mathrm{Ar}}$, and (h) RF at the Carr Inlet (CI) and Point Wells (PW) moorings and for the Puget Sound (PS) region. Gray shading shows $\pm 1 \sigma$ for CI. Text near the bottom of (a) indicates the number of years of moored SSS and SST observations contributing to the monthly seasonal cycle estimates. Text in (d) indicates the same information but for the moored $\mathrm{pH}$ observations. Slanted text in (a) indicates the total number of discrete observations contributing to the monthly seasonal cycle estimates. 


\section{The Supplement related to this article is available online at https://doi.org/10.5194/essd-10-1367-2018- supplement.}

Author contributions. AJF, SRA, RAF, and AJS designed the study and contributed to the data analysis and writing of the manuscript. JAN and WF provided much of the mooring and cruise data and contributed to interpretation of the results and manuscript review. AD contributed to interpretation of the results and manuscript review. MK wrote the sampling plan and collected and provided data for ECY discrete samples. JB, CK, and GP reviewed ECY data results, analyses, and the manuscript, and contributed to interpretation of the results.

Competing interests. The authors declare that they have no conflict of interest.

Acknowledgements. The Surface Ocean $\mathrm{CO}_{2}$ Atlas (SOCAT) is an international effort, endorsed by the International Ocean Carbon Coordination Project (IOCCP), the Surface Ocean Lower Atmosphere Study (SOLAS) and the Integrated Marine Biogeochemistry and Ecosystem Research program (IMBER), to deliver a uniformly quality-controlled surface ocean $\mathrm{CO}_{2}$ database. The many researchers and funding agencies responsible for the collection of data and quality control are thanked for their contributions to SOCAT. The moored carbon observations were supported by NOAA's Ocean Acidification Program and PMEL (NOAA FundRef 100000192). The University of Washington acknowledges that the mooring work from Puget Sound and Chá bă assets were supported by numerous technicians, captains, crew, and scientists, including Al Devol, John Mickett, and Beth Curry. Cruises were often staffed by trained volunteer students through the PRISM, NANOOS, and WOAC programs. Funding was provided by the US Integrated Ocean Observing System through NOAA to NANOOS; NOAA's Ocean Acidification Program; the State of Washington to the Washington Ocean Acidification Center (WOAC); the Navy to the Hood Canal Dissolved Oxygen Program; the University of Washington to PRISM and for Bellingham Bay; and EPA. The Washington Dept. of Ecology (Christopher Krembs, Julia Bos, Mya Keyzers, Skip Albertson, Laura Hermanson, and Carol Maloy) conducts long-term monitoring of Puget Sound including Hood Canal, Strait of Juan de Fuca, and Washington's coastal bays, collecting and providing quality-assured marine data since 1973. The authors thank David Carlson, Debby Ianson, and an anonymous reviewer for their constructive feedback, which has improved the manuscript. Andrea J. Fassbender was supported by the Postdocs Applying Climate Expertise (PACE) Fellowship Program, partially funded by the WOAC and NOAA Climate Program Office and administered by the UCAR Visiting Scientist Programs. This is PMEL contribution number 4632.

Edited by: David Carlson

Reviewed by: Debby Ianson and one anonymous referee
References

Adelsman, H. and Binder, L. W.: Washington State Blue Ribbon Panel on Ocean Acidification (2012): Ocean Acidification: From Knowledge to Action, Washington State's Strategic Response, Washington Department of Ecology, Olympia, Washington, USA, 2012.

Alford, M. H. and MacCready, P.: Flow and mixing in Juan de Fuca Canyon, Washington, Geophys. Res. Lett., 41, 1608-1615, https://doi.org/10.1002/2013GL058967, 2014.

Alin, S. R., Brainard, R., Price, N., Newton, J. A., Cohen, A., Peterson, W., DeCarlo, E., Shadwick, E., Noakes, S., and Bednaršek, N.: Characterizing the Natural System: Toward Sustained, Integrated Coastal Ocean Acidification Observing Networks to Facilitate Resource Management and Decision Support, Oceanography, 25, 92-107, https://doi.org/10.5670/oceanog.2015.34, 2015.

Andersson, A. J. and Mackenzie, F. T.: Revisiting four scientific debates in ocean acidification research, Biogeosciences, 9, 893905, https://doi.org/10.5194/bg-9-893-2012, 2012.

Bakker, D. C. E., Pfeil, B., O’Brien, K. M., Currie, K. I., Jones, S. D., Landa, C. S., Lauvset, S. K., Metzl, N., Munro, D. R., Nakaoka, S.-I., Olsen, A., Pierrot, D., Saito, S., Smith, K., Sweeney, C., Takahashi, T., Wada, C., Wanninkhof, R., Alin, S. R., Becker, M., Bellerby, R. G. J., Borges, A. V., Boutin, J., Bozec, Y., Burger, E., Cai, W.-J., Castle, R. D., Cosca, C. E., DeGrandpre, M. D., Donnelly, M., Eischeid, G., Feely, R. A., Gkritzalis, T., González-Dávila, M., Goyet, C., Guillot, A., Hardman-Mountford, N. J., Hauck, J., Hoppema, M., Humphreys, M. P., Hunt, C. W., Ibánhez, J. S. P., Ichikawa, T., Ishii, M., Juranek, L. W., Kitidis, V., Körtzinger, A., Koffi, U. K., Kozyr, A., Kuwata, A., Lefèvre, N., Lo Monaco, C., Manke, A., Marrec, P., Mathis, J. T., Millero, F. J., Monacci, N., Monteiro, P. M. S., Murata, A., Newberger, T., Nojiri, Y., Nonaka, I., Omar, A., M., Ono, T., Padín, X. A., Rehder, G., Rutgersson, A., Sabine, C. L., Salisbury, J., Santana-Casiano, J. M., Sasano, D., Schuster, U., Sieger, R., Skjelvan, I., Steinhoff, T., Sullivan, K., Sutherland, S. C., Sutton, A., Tadokoro, K., Telszewski, M., Thomas, H., Tilbrook, B., van Heuven, S., Vandemark, D., Wallace, D. W. R., and Woosley, R.: Surface Ocean $\mathrm{CO}_{2}$ Atlas (SOCAT) V4. PANGAEA, https://doi.org/10.1594/PANGAEA.866856, 2016 .

Bakker, D. C. E., Pfeil, B., Landa, C. S., Metzl, N., O’Brien, K. M., Olsen, A., Smith, K., Cosca, C., Harasawa, S., Jones, S. D., Nakaoka, S.-I., Nojiri, Y., Schuster, U., Steinhoff, T., Sweeney, C., Takahashi, T., Tilbrook, B., Wada, C., Wanninkhof, R., Alin, S. R., Balestrini, C. F., Barbero, L., Bates, N. R., Bianchi, A. A., Bonou, F., Boutin, J., Bozec, Y., Burger, E. F., Cai, W.-J., Castle, R. D., Chen, L., Chierici, M., Currie, K., Evans, W., Featherstone, C., Feely, R. A., Fransson, A., Goyet, C., Greenwood, N., Gregor, L., Hankin, S., Hardman-Mountford, N. J., Harlay, J., Hauck, J., Hoppema, M., Humphreys, M. P., Hunt, C. W., Huss, B., Ibánhez, J. S. P., Johannessen, T., Keeling, R., Kitidis, V., Körtzinger, A., Kozyr, A., Krasakopoulou, E., Kuwata, A., Landschützer, P., Lauvset, S. K., Lefèvre, N., Lo Monaco, C., Manke, A., Mathis, J. T., Merlivat, L., Millero, F. J., Monteiro, P. M. S., Munro, D. R., Murata, A., Newberger, T., Omar, A. M., Ono, T., Paterson, K., Pearce, D., Pierrot, D., Robbins, L. L., Saito, S., Salisbury, J., Schlitzer, R., Schneider, B., Schweitzer, R., Sieger, R., Skjelvan, I., Sullivan, K. F., Sutherland, S. C., Sutton, A. J., Tadokoro, K., Telszewski, M., Tuma, M., van Heuven, S. M. A. 
C., Vandemark, D., Ward, B., Watson, A. J., and Xu, S.: A multidecade record of high-quality $f \mathrm{CO}_{2}$ data in version 3 of the Surface Ocean $\mathrm{CO}_{2}$ Atlas (SOCAT), Earth Syst. Sci. Data, 8, 383413, https://doi.org/10.5194/essd-8-383-2016, 2016 b.

Barton, A., Hales, B., Waldbusser, G. G., Langdon, C., and Feely, R. A.: The Pacific oyster, Crassostrea gigas, shows negative correlation to naturally elevated carbon dioxide levels: Implications for near-term ocean acidification effects, Limnol. Oceanogr., 57, 698-710, https://doi.org/10.4319/lo.2012.57.3.0698, 2012.

Barton, A., Waldbusser, G. G., Feely, R. A., Weisberg, S. B., Newton, J. A., Hales, B., Cudd, S., Eudeline, B., Langdon, C., Jefferds, I., King, T., Suhrbier, A., and McLauglin, K.: Impacts of Coastal Acidification on the Pacific Northwest Shellfish Industry and Adaptation Strategies Implemented in Response, Oceanography, 25, 146-159, https://doi.org/10.5670/oceanog.2015.38, 2015.

Bates, N., Astor, Y., Church, M. J., Currie, K., Dore, J., GonaálezDávila, M., Lorenzoni, L., Muller-Karger, F., Olafsson, J. and Santana-Casiano, J. M.: A time-series view of changing ocean chemistry due to ocean uptake of anthropogenic $\mathrm{CO}_{2}$ and ocean acidification, Oceanography, 27, 126-141, https://doi.org/10.5670/oceanog.2014.16, 2014.

Bauer, J. E., Cai, W.-J., Raymond, P. A., Bianchi, T. S., Hopkinson, C. S., and Regnier, P. A. G.: The changing carbon cycle of the coastal ocean, Nature, 504, 61-70, https://doi.org/10.1038/nature12857, 2013.

Bednaršek, N., Feely, R. A., Reum, J. C. P., Peterson, B., Menkel, J., Alin, S. R., and Hales, B.: Limacina helicina shell dissolution as an indicator of declining habitat suitability owing to ocean acidification in the California Current Ecosystem, P. Roy. Soc. B-Biol. Sci., 281, 20140123, https://doi.org/10.1098/rspb.2014.0123, 2014.

Bednaršek, N., Klinger, T., Harvey, C. J., Weisberg, S. B., McCabe, R. M., Feely, R. A., Newton, J., and Tolimieri, N.: New ocean, new needs: Application of pteropod shell dissolution as a biological indicator for marine resource management, Ecol. Indic., 76, 240-244, https://doi.org/10.1016/j.ecolind.2017.01.025, 2017.

Boehm, A. B. A., Jacobson, M. Z. M., O’Donnell, M., Sutula, M., Wakefield, W. W., Weisberg, S. B., and Whiteman, E.: Ocean Acidification Science Needs for Natural Resource Managers of the North American West Coast, Oceanography, 25, 170-181, https://doi.org/10.5670/oceanog.2015.40, 2015.

Borges, A. V.: Present Day Carbon Dioxide Fluxes in the Coastal Ocean and Possible Feedbacks Under Global Change, in: Oceans and the Atmospheric Carbon Content, edited by: Duarte, P. and Santana-Casiano, J. M., Springer, Dordrecht, the Netherlands, 47-77, 2011.

Bos, J., Krembs, C., and Albertson, S.: Quality Assurance for Long-Term Marine Water Column pH Data, 16-03-042, available at: https://fortress.wa.gov/ecy/publications/SummaryPages/ 1603042.html (last access: 14 December 2017), 2016.

Bresnahan, P. J., Martz, T. R., Takeshita, Y., Johnson, K. S., and LaShomb, M.: Best practices for autonomous measurement of seawater $\mathrm{pH}$ with the Honeywell Durafet, Methods Oceanogr., 9, 44-60, https://doi.org/10.1016/j.mio.2014.08.003, 2014.

Brewer, P. G.: Direct Observation of the Oceanic $\mathrm{CO}_{2}$ Increase, Geophys. Res. Lett., 5, 12, https://doi.org/10.1029/GL005i012p00997, 1978.
Broecker, W. S., Takahashi, T., Simpson, H. J., and Peng, T.-H.: Fate of fossil fuel carbon dioxide and the global carbon budget., Science, 206, 409-18, https://doi.org/10.1126/science.206.4417.409, 1979.

Byrne, R. H., Mecking, S., Feely, R. A., and Liu, X.: Direct observations of basin-wide acidification of the North Pacific Ocean, Geophys. Res. Lett., 37, 1-5, https://doi.org/10.1029/2009GL040999, 2010.

Cai, W.-J., Hu, X., Huang, W.-J., Murrell, M. C., Lehrter, J. C., Lohrenz, S. E., Chou, W.-C., Zhai, W., Hollibaugh, J. T., Wang, Y., Zhao, P., Guo, X., Gundersen, K., Dai, M., and Gong, G.-C.: Acidification of subsurface coastal waters enhanced by eutrophication, Nat. Geosci., 4, 766-770, https://doi.org/10.1038/ngeo1297, 2011.

Caldeira, K. and Wickett, M. E.: Anthropogenic Carbon and Ocean pH, Nature, 425, 365-365, https://doi.org/10.1038/425365a, 2003.

Dickson, A. G.: An exact definition of total alkalinity and a procedure for the estimation of alkalinity and total inorganic carbon from titration data, Deep-Sea Res., 28, 609-623, https://doi.org/10.1016/0198-0149(81)90121-7, 1981.

Dickson, A. G.: Standard potential of the reaction?: $\mathrm{AgCl}(\mathrm{s})+1 / 2 \mathrm{H}_{2}(\mathrm{~g})=\mathrm{Ag}(\mathrm{s})+\mathrm{HCl}(\mathrm{aq})$, and the standard acidity constant of the ion $\mathrm{HSO}_{4}^{-}$in synthetic sea water from 273.15 to 318.15 K, J. Chem. Thermodyn., 22, 113-127, 1990.

Dickson, A. G. and Riley, J.: The effect of analytical error on the evaluation of the components of the aquatic carbon-dioxide system, Mar. Chem., 6, 77-85, https://doi.org/10.1016/03044203(78)90008-7, 1978.

Dickson, A. G., Sabine, C. L., and Christian, J. R.: Guide to best practices for ocean $\mathrm{CO}_{2}$ measurements, PICES Special Publication 3, 191 pp., available at: http://cdiac.ornl.gov/oceans/ Handbook_2007.html (last access: 14 December 2017), 2007.

Doney, S. C., Fabry, V. J., Feely, R. A., and Kleypas, J. A.: Ocean acidification: the other $\mathrm{CO}_{2}$ problem, Ann. Rev. Mar. Sci., 1, 169-192, https://doi.org/10.1146/annurev.marine.010908.163834, 2009.

Dunne, J. P., Devol, A. H., and Emerson, S.: The Oceanic Remote Chemical/Optical Analyzer (ORCA) - An Autonomous Moored Profiler, J. Atmos. Ocean. Tech., 19, 1709-1721, https://doi.org/10.1175/15200426(2002)019<1709:TORCOA>2.0.CO;2, 2002.

Ekstrom, J. A., Suatoni, L., Cooley, S. R., Pendleton, L. H., Waldbusser, G. G., Cinner, J. E., Ritter, J., Langdon, C., van Hooidonk, R., Gledhill, D. K., Wellman, K., Beck, M. W., Brander, L. M., Rittschof, D., Doherty, C., Edwards, P. E. T. and Portela, R.: Vulnerability and adaptation of US shellfisheries to ocean acidification, Nat. Clim. Change, 5, 207-214, https://doi.org/10.1038/nclimate2508, 2015.

Evans, W., Hales, B., and Strutton, P. G.: Seasonal cycle of surface ocean $p \mathrm{CO}_{2}$ on the Oregon shelf, J. Geophys. Res., 116, 260 272, https://doi.org/10.1029/2010JC006625, 2011.

Evans, W., Hales, B., and Strutton, P. G.: $p \mathrm{CO}_{2}$ distributions and air-water $\mathrm{CO}_{2}$, Estuar. Coast. Shelf S., 117, 260-272, https://doi.org/10.1016/j.ecss.2012.12.003, 2013.

Fassbender, A. J., Sabine, C. L., Lawrence-Slavas, N., De Carlo, E. H. H., Meinig, C., Maenner-Jones, S., and Maenner Jones, S.: Robust Sensor for Extended Autonomous Measurements of Sur- 
face Ocean Dissolved Inorganic Carbon, Environ. Sci. Technol., 49, 3628-3635, https://doi.org/10.1021/es5047183, 2015.

Fassbender, A. J., Sabine, C. L., and Feifel, K. M.: Consideration of coastal carbonate chemistry in understanding biological calcification, Geophys. Res. Lett., 43, 4467-4476, https://doi.org/10.1002/2016GL068860, 2016.

Fassbender, A. J., Alin, S. R., Feely, R. A., Sutton, A. J., Newton, J. A., and Byrne, R. H.: Estimating Total Alkalinity in the Washington State Coastal Zone: Complexities and Surprising Utility for Ocean Acidification Research, Estuar. Coast., 40, 404-418, https://doi.org/10.1007/s12237-016-0168-z, 2017a.

Fassbender, A. J., Sabine, C. L., and Palevsky, H. I.: Nonuniform ocean acidification and attenuation of the ocean carbon sink, Geophys. Res. Lett., 44, 8404-8413, https://doi.org/10.1002/2017GL074389, 2017b.

Fassbender, A. J., Alin, S. R., Feely, R. A., Sutton, A. J., Newton, J. A., Krembs, C., Bos, J., Keyzers, M., Devol, A., Ruef, W., and Pelletier, G.: Seasonal Carbonate Chemistry Variability in Marine Surface Waters of the Pacific Northwest, Data Archive, (Version 1.0) [Data set], Zenodo, https://doi.org/10.5281/zenodo.1184657, 2018.

Feely, R. A., Sabine, C. L., Lee, K., Berelson, W. M., Kleypas, J. A., Fabry, V. J., and Millero, F. J.: Impact of anthropogenic $\mathrm{CO}_{2}$ on the $\mathrm{CaCO}_{3}$ system in the oceans., Science, 305, 362-366, https://doi.org/10.1126/science.1097329, 2004.

Feely, R. A., Sabine, C. L., Hernandez-Ayon, J. M., Ianson, D., and Hales, B.: Evidence for Upwelling of Corrosive "Acidified" Water onto the Continental Shelf, Science, 320, 1490-1492, https://doi.org/10.1126/science.1155676, 2008.

Feely, R. A., Doney, S. C., and Cooley, S. R.: Ocean Acidification: Present Conditions and Future Changes in a High- $\mathrm{CO}_{2}$ World, Oceanography, 22, 36-47, https://doi.org/10.5670/oceanog.2009.95, 2009.

Feely, R. A., Alin, S. R., Newton, J. A., Sabine, C. L., Warner, M. J., Devol, A., Krembs, C., and Maloy, C.: The combined effects of ocean acidification, mixing, and respiration on $\mathrm{pH}$ and carbonate saturation in an urbanized estuary, Estuar. Coast. Shelf S., 88, 442-449, https://doi.org/10.1016/j.ecss.2010.05.004, 2010.

Feely, R. A. and Sabine, C. L.: Dissolved inorganic carbon, alkalinity, temperature, salinity and other variables collected from discrete sample and profile observations using Alkalinity titrator, CTD and other instruments from WECOMA in the U.S. West Coast California Current System from 200705-11 to 2007-06-14 (NODC Accession 0083685), Version 2.2. National Oceanographic Data Center, NOAA, Dataset, https://doi.org/10.3334/CDIAC/OTG (last access: 19 July 2018), 2013.

Feely, R. A., Alin, S. R., Hales, B., Johnson, G. C., Byrne, R. H., Peterson, W. T., Liu, X., and Greeley, D.: Dissolved inorganic carbon, total alkalinity, $\mathrm{pH}$ and other variables collected from profile and discrete sample observations using CTD, Niskin bottle, and other instruments from NOAA Ship Fairweather and the R/V Point Sur in the U.S. West Coast California Current System during the 2013 West Coast Ocean Acidification Cruise (WCOA2013) from 201308-05 to 2013-08-28 (NCEI Accession 0132082), Version 3.3, NOAA National Centers for Environmental Information. Dataset, https://doi.org/10.7289/V5C53HXP (last access: 19 July 2018), 2015a.
Feely, R. A., Alin, S. R., Hales, B., Johnson, G. C., Juranek, L. W., Byrne, R. H., Peterson, W. T., Goni, M., Liu, X., and Greeley, D.: Dissolved inorganic carbon, total alkalinity, $\mathrm{pH}$, temperature, salinity and other variables collected from profile and discrete sample observations using CTD, Niskin bottle, and other instruments from R/V Wecoma in the U.S. West Coast California Current System during the 2011 West Coast Ocean Acidification Cruise (WCOA2011) from 201108-12 to 2011-08-30 (NODC Accession 0123467). Version 2.2. National Oceanographic Data Center, NOAA. Dataset, https://doi.org/10.7289/V5JQ0XZ1 (last access: 26 July 2018), 2015b.

Feely, R. A., Alin, S. R., Hales, B., Johnson, G. C., Juranek, L. W., Byrne, R. H., Peterson, W. T., and Greeley, D.: Dissolved inorganic carbon, alkalinity, temperature, salinity and other variables collected from discrete sample and profile observations using Alkalinity titrator, CTD and other instruments from NOAA Ship Bell M. Shimada in the Columbia River estuary - Washington/Oregon, Gulf of the Farallones National Marine Sanctuary and others from 2012-09-04 to 2012-09-17 (NCEI Accession 0157445), Version 1.1. NOAA National Centers for Environmental Information, Dataset, https://www.nodc.noaa.gov/ocads/data/ 0157445.xml (last access: 19 July 2018), 2016a.

Feely, R. A., Alin, S. R., Carter, B., Bednaršek, N., Hales, B., Chan, F., Hill, T. M., Gaylord, B., Sanford, E., Byrne, R. H., Sabine, C. L., Greeley, D., and Juranek, L.: Chemical and biological impacts of ocean acidification along the west coast of North America, Estuar. Coast. Shelf S., 183, 260-270, https://doi.org/10.1016/j.ecss.2016.08.043, 2016b.

Gray, S. E. C., DeGrandpre, M. D., Moore, T. S., Martz, T. R., Friederich, G. E., and Johnson, K. S.: Applications of in situ pH measurements for inorganic carbon calculations, Mar. Chem., 125, 82-90, https://doi.org/10.1016/j.marchem.2011.02.005, 2011.

Harris, K.: Aragonite saturation state dynamics in a coastal upwelling zone, Geophys. Res., 40, 2720-2725, https://doi.org/10.1002/grl.50460, 2013.

Hauri, C., Gruber, N., Vogt, M., Doney, S. C., Feely, R. A., Lachkar, Z., Leinweber, A., McDonnell, A. M. P., Munnich, M., and Plattner, G.-K.: Spatiotemporal variability and long-term trends of ocean acidification in the California Current System, Biogeosciences, 10, 193-216, https://doi.org/10.5194/bg-10-193-2013, 2013.

Hickey, B. M. and Banas, N. S.: Why is the Northern End of the California Current System So Productive?, Oceanography, 21, 90-107, 2008.

Hofmann, G. E., Smith, J. E., Johnson, K. S., Send, U., Levin, L. A., Micheli, F., Paytan, A., Price, N. N., Peterson, B., Takeshita, Y., Matson, P. G., Crook, E. D., Kroeker, K. J., Gambi, M. C., Rivest, E. B., Frieder, C. A., Yu, P. C., and Martz, T. R.: High-Frequency Dynamics of Ocean pH: A Multi-Ecosystem Comparison, edited by: Chin, W.-C., PLoS One, 6, e28983, https://doi.org/10.1371/journal.pone.0028983, 2011.

Johnson, K. M., Dickson, A. G., Eischeid, G., Goyet, C., Guenther, P., Key, R. M., Millero, F. J., Purkerson, D., Sabine, C. L., Schottle, R. G., Wallace, D. W. R., Wilke, R. J., and Winn, C. D.: Coulometric total carbon dioxide analysis for marine studies: assessment of the quality of total inorganic carbon measurements made during the US Indian Ocean $\mathrm{CO}_{2}$ Survey 1994 
1996, Mar. Chem., 63, 21-37, https://doi.org/10.1016/S03044203(98)00048-6, 1998.

Keyzers, M.: Quality Assurance Project Plan: Puget Sound Total Alkalinity and Dissolved Inorganic Carbon Pilot Project, Olympia, Washington, USA, available at: https://fortress.wa.gov/ ecy/publications/documents/1403116.pdf (last access: 14 December 2017), 2014.

Keyzers, M.: Puget Sound Total Alkalinity and Dissolved Inorganic Carbon Pilot Project: Feasibility Report, Olympia, Washington, USA, available at: https://fortress.wa.gov/ecy/publications/ documents/1603032.pdf (last access: 14 December 2017), 2016.

Lewis, E. and Wallace, D. W. R.: MATLAB Program Developed for $\mathrm{CO}_{2}$ System Calculations. ORNL/CDIAC-105., Carbon Dioxide Inf. Anal. Center, Oak Ridge Natl. Lab. US Dep. Energy, Oak Ridge, Tennessee, USA, 1998.

Liu, X., Patsavas, M. C., and Byrne, R. H.: Purification and characterization of meta-cresol purple for spectrophotometric seawater pH measurements., Environ. Sci. Technol., 45, 4862-4868, https://doi.org/10.1021/es200665d, 2011.

Lueker, T. J., Dickson, A. G., and Keeling, C. D.: Ocean $p \mathrm{CO}_{2}$ calculated from dissolved inorganic carbon, alkalinity, and equations for $\mathrm{K}_{1}$ and $\mathrm{K}_{2}$ : validation based on laboratory measurements of $\mathrm{CO}_{2}$ in gas and seawater at equilibrium, Mar. Chem., 70, 105-119, https://doi.org/10.1016/S0304-4203(00)00022-0, 2000.

Martin, W. D. and MacCready, P.: Influence of large-scale tidal asymmetry on subtidal dynamics in the western Strait of Juan de Fuca, J. Geophys. Res., 116, C02009, https://doi.org/10.1029/2010JC006363, 2011.

Martz, T., Mclaughlin, K., and Weisberg, S. B.: California Current Acidification Network Best Practices for autonomous measurement of seawater $\mathrm{pH}$ with the Honeywell Durafet $\mathrm{pH}$ sensor, available at: ftp://ftp.sccwrp.org/pub/download/ DOCUMENTS/TechnicalReports/861_CCAN_Durafet_Best_ Practices_Manual.pdf (last access: 14 December 2017), 2015.

McElhany, P. and Shallin Busch, D.: Appropriate $p \mathrm{CO}_{2}$ treatments in ocean acidification experiments, Mar. Biol., 160, 1807-1812, https://doi.org/10.1007/s00227-012-2052-0, 2013.

Millero, F. J.: The Marine Inorganic Carbon Cycle, Chem. Rev., 107, 308-341, https://doi.org/10.1021/cr0503557, 2007.

Millero, F. J., Zhang, J.-Z., Lee, K., and Campbell, D. M.: Titration alkalinity of seawater, Mar. Chem., 44, 153-165, https://doi.org/10.1016/0304-4203(93)90200-8, 1993.

Moore-Maley, B. L., Ianson, D., and Allen, S. E.: The sensitivity of estuarine aragonite saturation state and $\mathrm{pH}$ to the carbonate chemistry of a freshet-dominated river, Biogeosciences, 15, 3743-3760, https://doi.org/10.5194/bg-15-3743-2018, 2018.

Mucci, A.: The solubility of calcite and aragonite in seawater at various salinities, temperatures, and one atmosphere total pressure, Am. J. Sci., 283, 780-799, https://doi.org/10.2475/ajs.283.7.780, 1983.

Newton, J. A. and Devol, A. H.: Quality Assurance Project Plan: Long-term, High Resolution Marine Water Quality Monitoring in Puget Sound using Profiling Buoys, 2012-2013 Activities, available at: http://orcabase.ocean.washington.edu/ORCA_ QAPP.pdf (last access: 14 December 2017), 2012.

Newton, J. A., Siegel, E., and Albertson, S. L.: Oceanographic Changes in Puget Sound and the Strait of Juan de Fuca dur- ing the 2000-01 Drought, Can. Water Resour. J., 28, 715-728, https://doi.org/10.4296/cwrj2804715, 2003.

Orr, J. C., Epitalon, J.-M., and Gattuso, J.-P.: Comparison of ten packages that compute ocean carbonate chemistry, Biogeosciences, 12, 1483-1510, https://doi.org/10.5194/bg-12-14832015, 2015.

Pelletier, G., Bianucci, L., Long, W., Khangaonkar, T., Mohamedali, T., Ahmed, A., and Figueroa-Kaminsky, C.: Salish Sea Model: Ocean Acidification Module and the Response to Regional Anthropogenic Nutrient Sources, available at: https://fortress.wa. gov/ecy/publications/SummaryPages/1703009.html, last access: 14 December 2017.

Pelletier, G., Roberts, M., Keyzers, M., and Alin, S. R.: Seasonal variation in aragonite saturation in surface waters of Puget Sound - a pilot study, Elem. Sci. Anth., 6, 5, https://doi.org/10.1525/elementa.270, 2018

Pfeil, B., Olsen, A., Bakker, D. C. E., Hankin, S., Koyuk, H., Kozyr, A., Malczyk, J., Manke, A., Metzl, N., Sabine, C. L., Akl, J., Alin, S. R., Bates, N., Bellerby, R. G. J., Borges, A., Boutin, J., Brown, P. J., Cai, W.-J., Chavez, F. P., Chen, A., Cosca, C., Fassbender, A. J., Feely, R. A., González-Dávila, M., Goyet, C., Hales, B., Hardman-Mountford, N., Heinze, C., Hood, M., Hoppema, M., Hunt, C. W., Hydes, D., Ishii, M., Johannessen, T., Jones, S. D., Key, R. M., Körtzinger, A., Landschützer, P., Lauvset, S. K., Lefèvre, N., Lenton, A., Lourantou, A., Merlivat, L., Midorikawa, T., Mintrop, L., Miyazaki, C., Murata, A., Nakadate, A., Nakano, Y., Nakaoka, S., Nojiri, Y., Omar, A. M., Padin, X. A., Park, G.-H., Paterson, K., Perez, F. F., Pierrot, D., Poisson, A., Ríos, A. F., Santana-Casiano, J. M., Salisbury, J., Sarma, V. V. S. S., Schlitzer, R., Schneider, B., Schuster, U., Sieger, R., Skjelvan, I., Steinhoff, T., Suzuki, T., Takahashi, T., Tedesco, K., Telszewski, M., Thomas, H., Tilbrook, B., Tjiputra, J., Vandemark, D., Veness, T., Wanninkhof, R., Watson, A. J., Weiss, R., Wong, C. S., and Yoshikawa-Inoue, H.: A uniform, quality controlled Surface Ocean $\mathrm{CO}_{2}$ Atlas (SOCAT), Earth Syst. Sci. Data, 5, 125-143, https://doi.org/10.5194/essd-5-125-2013, 2013.

Raymond, P. A. and Cole, J. J.: Increase in the Export of Alkalinity from North America's Largest River, Science, 301, 88-91, https://doi.org/10.1126/science.1083788, 2003.

Raymond, P. A., Oh, N.-H., Turner, R. E., and Broussard, W.: Anthropogenically enhanced fluxes of water and carbon from the Mississippi River, Nature, 451, 449-452, https://doi.org/10.1038/nature06505, 2008.

Regnier, P., Friedlingstein, P., Ciais, P., Mackenzie, F. T., Gruber, N., Janssens, I. A., Laruelle, G. G., Lauerwald, R., Luyssaert, S., Andersson, A. J., Arndt, S., Arnosti, C., Borges, A. V, Dale, A. W., Gallego-Sala, A., Goddéris, Y., Goossens, N., Hartmann, J., Heinze, C., Ilyina, T., Joos, F., LaRowe, D. E., Leifeld, J., Meysman, F. J. R., Munhoven, G., Raymond, P. A., Spahni, R., Suntharalingam, P., and Thullner, M.: Anthropogenic perturbation of the carbon fluxes from land to ocean, Nat. Geosci., 6, 597-607, https://doi.org/10.1038/ngeo1830, 2013.

Revelle, R. and Suess, H. E.: Carbon dioxide exchange between atmosphere and ocean and the question of an increase of atmospheric $\mathrm{CO}_{2}$ during the past decades, Tellus, 9, 18-27, https://doi.org/10.1111/j.2153-3490.1957.tb01849.x, 1957.

Sabine, C. L., Feely, R. A., Gruber, N., Key, R. M., Lee, K., Bullister, J. L., Wanninkhof, R., Wong, C. S., Wallace, D. W. ., Tilbrook, B., Millero, F. J., Peng, T.-H., Kozyr, A., Ono, T., and 
Rios, A. F.: The Oceanic Sink for Anthropogenic $\mathrm{CO}_{2}$, Science, 305, 367-371, https://doi.org/10.1126/science.1097403, 2004.

Sabine, C. L., Hankin, S., Koyuk, H., Bakker, D. C. E., Pfeil, B., Olsen, A., Metzl, N., Kozyr, A., Fassbender, A., Manke, A., Malczyk, J., Akl, J., Alin, S. R., Bellerby, R. G. J., Borges, A., Boutin, J., Brown, P. J., Cai, W.-J., Chavez, F. P., Chen, A., Cosca, C., Feely, R. A., González-Dávila, M., Goyet, C., Hardman-Mountford, N., Heinze, C., Hoppema, M., Hunt, C. W., Hydes, D., Ishii, M., Johannessen, T., Key, R. M., Körtzinger, A., Landschützer, P., Lauvset, S. K., Lefèvre, N., Lenton, A., Lourantou, A., Merlivat, L., Midorikawa, T., Mintrop, L., Miyazaki, C., Murata, A., Nakadate, A., Nakano, Y., Nakaoka, S., Nojiri, Y., Omar, A. M., Padin, X. A., Park, G.-H., Paterson, K., Perez, F. F., Pierrot, D., Poisson, A., Ríos, A. F., Salisbury, J., Santana-Casiano, J. M., Sarma, V. V. S. S., Schlitzer, R., Schneider, B., Schuster, U., Sieger, R., Skjelvan, I., Steinhoff, T., Suzuki, T., Takahashi, T., Tedesco, K., Telszewski, M., Thomas, H., Tilbrook, B., Vandemark, D., Veness, T., Watson, A. J., Weiss, R., Wong, C. S., and Yoshikawa-Inoue, H.: Surface Ocean $\mathrm{CO}_{2}$ Atlas (SOCAT) gridded data products, Earth Syst. Sci. Data, 5, 145-153, https://doi.org/10.5194/essd-5-145-2013, 2013.

Somero, G. N., Beers, J. M., Chan, F., Hill, T. M., Klinger, T., and Litvin, S. Y.: What Changes in the Carbonate System, Oxygen, and Temperature Portend for the Northeastern Pacific Ocean: A Physiological Perspective, Bioscience, 66, 14-26, https://doi.org/10.1093/biosci/biv162, 2016.

Sundquist, E. T., Plummer, L. N., and Wigley, T. M. L.: Carbon dioxide in the ocean surface: The homogeneous buffer factor, Science, 204, 1203-1205, https://doi.org/10.1126/science.204.4398.1203, 1979.

Sutton, A. J., Sabine, C. L., Newton, J., Mickett, J., Musielewicz, S., Maenner Jones, S., Dietrich, C., Bott, R., and Osborne, J.: High-resolution ocean and atmosphere $p \mathrm{CO}_{2}$ timeseries measurements from mooring LaPush_125W_48N in the Pacific Ocean (NODC Accession 0100072), Version 8.8, National Oceanographic Data Center, NOAA, Dataset, https://doi.org/10.3334/CDIAC/OTG (last access: 19 July 2018), 2012.

Sutton, A. J., Sabine, C. L., Newton, J., Mickett, J., Musielewicz, S., Maenner Jones, S., Dietrich, C., Bott, R., and Osborne, J.: High-resolution ocean and atmosphere $p \mathrm{CO}_{2}$ time-series measurements from mooring WA_125W_47N in the North Pacific Ocean, US West Coast from 2006-0623 to 2015-10-30 (NODC Accession 0115322), Version 10.10, National Oceanographic Data Center, NOAA, Dataset, https://doi.org/10.3334/CDIAC/OTG (last access: 19 July 2018), 2013.

Sutton, A. J., Sabine, C. L., Newton, J., Mickett, J., Musielewicz, S., Maenner Jones, S., Dietrich, C., Bott, R., and Osborne, J.: High-resolution ocean and atmosphere $p \mathrm{CO}_{2}$ time-series measurements from mooring Dabob_122W_478N (NODC Accession 0116715), Version 3.3, National Oceanographic Data Center, NOAA, Dataset, https://doi.org/10.3334/CDIAC/OTG (last access: 19 July 2018), 2014a.

Sutton, A. J., Sabine, C. L., Maenner-Jones, S., Lawrence-Slavas, N., Meinig, C., Feely, R. A., Mathis, J. T., Musielewicz, S., Bott, R., McLain, P. D., Fought, H. J., and Kozyr, A.: A high-frequency atmospheric and seawater $p \mathrm{CO}_{2}$ data set from 14 open-ocean sites using a moored autonomous system, Earth Syst. Sci. Data, 6, 353-366, https://doi.org/10.5194/essd-6-353-2014, 2014b.

Sutton, A. J., Sabine, C. L., Newton, J., Mickett, J., Musielewicz, S., Maenner Jones, S., Dietrich, C., Bott, R., and Osborne, J.: High-resolution ocean and atmosphere $p \mathrm{CO}_{2}$ timeseries measurements from mooring Twanoh_123W_47N (NCEI Accession 0157600), Version 2.2, NOAA National Centers for Environmental Information, Dataset, https://doi.org/10.3334/CDIAC/OTG (last access: 19 July 2018), 2016a.

Sutton, A. J., Sabine, C. L., Feely, R. A., Cai, W.-J., Cronin, M. F., McPhaden, M. J., Morell, J. M., Newton, J. A., Noh, J.-H., Ólafsdóttir, S. R., Salisbury, J. E., Send, U., Vandemark, D. C., and Weller, R. A.: Using present-day observations to detect when anthropogenic change forces surface ocean carbonate chemistry outside preindustrial bounds, Biogeosciences, 13, 5065-5083, https://doi.org/10.5194/bg-13-5065-2016, 2016 b.

Takahashi, T., Broecker, W. S., Werner, S. R., and Bainbridge, A. E.: Carbonate chemistry of the surface waters of the worlds ocean, in: Isotope marine Chemistry, edited by: Edward, K. S., Goldberg, D., and Horibe, Y., Geochemistry Research Association, 291-326, 1980.

Takahashi, T., Goddard, J. G., and Chipman, D. W.: Seasonal variation of $\mathrm{CO}_{2}$ and nutrients in the high-latitude surface oceans: A comparative study, Global Biogeochem. Cy., 7, 843-878, 1993.

Takahashi, T., Sutherland, S. C., Wanninkhof, R., Sweeney, C., Feely, R. A., Chipman, D. W., Hales, B., Friederich, G. E., Chavez, F. P., Sabine, C. L., Watson, A. J., Bakker, D. C. E., Schuster, U., Metzl, N., Yoshikawa-Inoue, H., Ishii, M., Midorikawa, T., Nojiri, Y., Körtzinger, A., Steinhoff, T., Hoppema, M., Olafsson, J., Arnarson, T. S., Tilbrook, B., Johannessen, T., Olsen, A., Bellerby, R., Wong, C. S., Delille, B., Bates, N. R., and de Baar, H. J. W.: Climatological mean and decadal change in surface ocean $p \mathrm{CO}_{2}$, and net sea-air $\mathrm{CO}_{2}$, flux over the global oceans, Deep-Res. Pt II, 56, 554-577, https://doi.org/10.1016/j.dsr2.2008.12.009, 2009.

Takahashi, T., Sutherland, S. C., Chipman, D. W., Goddard, J. G., and $\mathrm{Ho}, \mathrm{C}$. : Climatological distributions of $\mathrm{pH}, p \mathrm{CO}_{2}$, total $\mathrm{CO}_{2}$, alkalinity, and $\mathrm{CaCO}_{3}$ saturation in the global surface ocean, and temporal changes at selected locations, Mar. Chem., 164, 95125, https://doi.org/10.1016/j.marchem.2014.06.004, 2014.

Takeshita, Y., Frieder, C. A., Martz, T. R., Ballard, J. R., Feely, R. A., Kram, S., Nam, S., Navarro, M. O., Price, N. N., and Smith, J. E.: Including high-frequency variability in coastal ocean acidification projections, Biogeosciences, 12, 5853-5870, https://doi.org/10.5194/bg-12-5853-2015, 2015.

Thomson, R. E., Mihály, S. F., and Kulikov, E. A.: Estuarine versus transient flow regimes in Juan de Fuca Strait, J. Geophys. Res., 112, C09022, https://doi.org/10.1029/2006JC003925, 2007.

UNESCO: Protocols for the Joint Global Ocean Flux Study (JGOFS) Core Measurements, IOC Manual and Guides 29, available at: http://unesdoc.unesco.org/images/0009/000997/ 099739eo.pdf (last access: 14 December 2017), 1994.

Uppström, L. R.: The boron-chlorinity ratio of deep seawater from the Pacific Ocean, Deep. Res. Pt I, 21, 161-162, 1974.

van Heuven, S. M. A. C., Pierrot, D., Rae, J. W. B., Lewis, E., and Wallace, D. W.: MATLAB Program Developed for $\mathrm{CO}_{2}$ System Calculations. ORNL/CDIAC-105b., ORNL/CDIAC105b. Carbon Dioxide Inf. Anal. Center, Oak Ridge 
Natl. Lab. US Dep. Energy, Oak Ridge, Tennessee, USA, https://doi.org/10.3334/CDIAC/otg.CO2SYS_MATLAB_v1.1, 2011.

Wahl, M., Saderne, V., and Sawall, Y.: How good are we at assessing the impact of ocean acidification in coastal systems? Limitations, omissions and strengths of commonly used experimental approaches with special emphasis on the neglected role of fluctuations, Mar. Freshwater Res., 67, 25-36, https://doi.org/10.1071/MF14154, 2016.

Waldbusser, G. G. and Salisbury, J. E.: Ocean acidification in the coastal zone from an organism's perspective: multiple system parameters, frequency domains, and habitats, Annu. Rev. Mar. Sci., 6, 221-247, https://doi.org/10.1146/annurev-marine121211-172238, 2014.

Weisberg, S. B., Bednaršek, N., Feely, R. A., Chan, F., Boehm, A. B., Sutula, M., Ruesink, J. L., Hales, B., Largier, J. L., and Newton, J. A.: Water quality criteria for an acidifying ocean: Challenges and opportunities for improvement, Ocean Coast. Manage., 126, 31-41, https://doi.org/10.1016/j.ocecoaman.2016.03.010, 2016.
Wong, P. P., Losada, I. J., Gattuso, J.-P., Hinkel, J., Khattabi, A., McInnes, K. L., Saito, Y., and Sallenger, A.: Coastal ecosystems and low-lying areas, in Climate Change 2014: Impacts, Adaptation, and Vulnerability. Part A: Global and Sectoral Aspects, Contribution of Working Group II to the Fifth Assessment Report of the Intergovernmental Panel on Climate Change, edited by: Field, C. B., Barros, V. R., Dokken, D. J., Mach, K. J., Mastrandrea, M. D., Bilir, T. E., Chatterjee, M., Ebi, K. L., Estrada, Y. O., Genova, R. C., Girma, B., Kissel, E. S., Levy, A. N., MacCracken, S., Mastrandrea, P. R., and White, L. L., Cambridge University Press, Cambridge, UK and New York, NY, USA, 361409, 2014. 